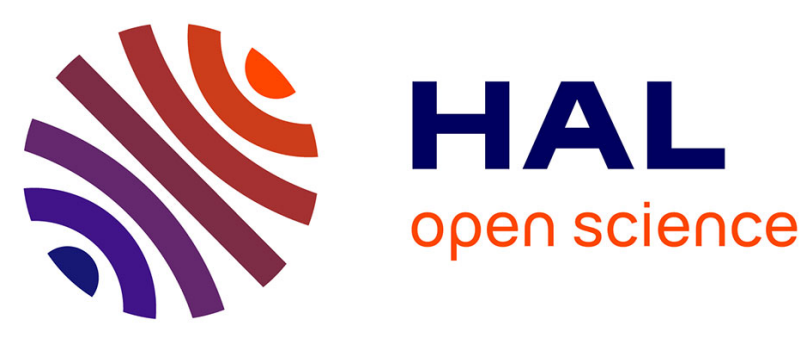

\title{
Stable divalent germanium, tin and lead amino(ether)-phenolate monomeric complexes: structural features, inclusion heterobimetallic complexes, and ROP catalysis
}

Lingfang Wang, Sorin-Claudiu Roşca, Valentin Poirier, Sourisak Sinbandhit, Vincent Dorcet, Thierry Roisnel, Jean-François Carpentier, Yann Sarazin

\section{To cite this version:}

Lingfang Wang, Sorin-Claudiu Roşca, Valentin Poirier, Sourisak Sinbandhit, Vincent Dorcet, et al.. Stable divalent germanium, tin and lead amino(ether)-phenolate monomeric complexes: structural features, inclusion heterobimetallic complexes, and ROP catalysis. Dalton Transactions, 2013, 43 (11), pp.4268 - 4286. 10.1039/c3dt51681d . hal-00860197

\section{HAL Id: hal-00860197}

https://hal-univ-rennes1.archives-ouvertes.fr/hal-00860197

Submitted on 10 Sep 2013

HAL is a multi-disciplinary open access archive for the deposit and dissemination of scientific research documents, whether they are published or not. The documents may come from teaching and research institutions in France or abroad, or from public or private research centers.
L'archive ouverte pluridisciplinaire HAL, est destinée au dépôt et à la diffusion de documents scientifiques de niveau recherche, publiés ou non, émanant des établissements d'enseignement et de recherche français ou étrangers, des laboratoires publics ou privés. 


\title{
Dalton \\ Transactions
}

Cite this: DOI: $10.1039 / \mathrm{c3dt5} 1681 \mathrm{~d}$

\section{Stable divalent germanium, tin and lead amino(ether)- phenolate monomeric complexes: structural features, inclusion heterobimetallic complexes, and ROP catalysis $\dagger$}

\author{
Lingfang Wang, ${ }^{a}$ Sorin-Claudiu Roşca, ${ }^{\text {a Valentin Poirier, }}{ }^{\text {a }}$ Sourisak Sinbandhit, ${ }^{\text {, }}$ \\ Vincent Dorcet, ${ }^{\mathrm{c}}$ Thierry Roisnel, ${ }^{\mathrm{c}}$ Jean-François Carpentier ${ }^{\mathrm{a}}$ and Yann Sarazin*a
}

Stable germanium(॥) and lead(॥) amido complexes $\left\{\mathrm{LO}^{\prime}\right\} \mathrm{M}\left(\mathrm{N}\left(\mathrm{SiMe}_{3}\right)_{2}\right)\left(\mathrm{M}=\mathrm{Ge}^{\|}, \mathrm{Pb}^{\prime \prime}\right)$ bearing amino(ether)phenolate ligands are readily available using the proteo-ligands $\left\{\mathrm{LO}^{i}\right\} \mathrm{H}$ of general formula $2-\mathrm{CH}_{2} \mathrm{NR}_{2}-4,6-\mathrm{tBu}_{2}-\mathrm{C}_{6} \mathrm{H}_{2} \mathrm{OH}\left(i=1, \mathrm{NR}_{2}=\mathrm{N}\left(\left(\mathrm{CH}_{2}\right)_{2} \mathrm{OCH}_{3}\right)_{2} ; i=2, \mathrm{NR}_{2}=\mathrm{NEt}_{2} ; i=3, \mathrm{NR}_{2}=\right.$ aza-15-crown-5) and $\mathrm{M}\left(\mathrm{N}\left(\mathrm{SiMe}_{3}\right)_{2}\right)_{2}$ precursors. The molecular structures of these germylenes and plumbylenes, as well as those of $\left\{\mathrm{LO}^{3}\right\} \mathrm{GeCl},\left\{\mathrm{LO}^{3}\right\} \mathrm{SnCl}$ and of the congeneric $\left\{\mathrm{LO}^{4}\right\} \mathrm{Sn}$ " $\left(\mathrm{N}\left(\mathrm{SiMe}_{3}\right)_{2}\right)$ where $\mathrm{NR}_{2}=$ aza-12-crown-4, have been determined crystallographically. All complexes are monomeric, with 3-coordinate metal centres. The phenolate systematically acts as a $\mathrm{N}^{\wedge} \mathrm{O}_{\text {phenolate }}$ bidentate ligand, with no interactions between the metal and the $\mathrm{O}_{\text {side-arm }}$ atoms in these cases (for $\left\{\mathrm{LO}^{1}\right\}^{-},\left\{\mathrm{LO}^{3}\right\}^{-}$and $\left\{\mathrm{LO}^{4}\right\}^{-}$) where they could potentially arise. For each family, the lone pair of electrons essentially features $n s^{2}$ character, and there is little, if any, hybridization of the valence orbitals. Heterobimetallic complexes $\left\{\mathrm{LO}^{3}\right\} \mathrm{M}\left(\mathrm{N}\left(\mathrm{SiMe}_{3}\right)_{2}\right)$. LiOTf, where the $\mathrm{Li}^{+}$cation sits inside the tethered crown-ether, were prepared by reaction of $\left\{\mathrm{LO}^{3}\right\} \mathrm{M}(\mathrm{N}-$ $\left.\left(\mathrm{SiMe}_{3}\right)_{2}\right)$ and LiOTf $\left(\mathrm{M}=\mathrm{Ge}^{\prime \prime}, \mathrm{Sn}^{\prime \prime}\right)$. The inclusion of $\mathrm{Li}^{+}$(featuring a close contact with the triflate anion) in the macrocycle bears no influence on the coordination sphere of the divalent tetrel element. In association with $\mathrm{iPrOH}$, the amido germylenes, stannylenes and plumbylenes catalyse the controlled polymerisation of L- and racemic lactide. The activity increases linearly according to $\mathrm{Ge}^{\mathrm{I}} \ll \mathrm{Sn}^{\|} \ll \mathrm{Pb}^{\|}$. The simple germylenes generate very sluggish catalysts, but the activity is significantly boosted if the heterobimetallic complex $\left\{\mathrm{LO}^{3}\right\} \mathrm{Ge}\left(\mathrm{N}\left(\mathrm{SiMe}_{3}\right)_{2}\right)$. LiOTf is used instead. On the other hand, with 10-25 equiv. of iPrOH, the plumbylenes afford highly active binary catalysts, converting 1000 or 5000 equiv. of monomer at $60{ }^{\circ} \mathrm{C}$ within 3 or $45 \mathrm{~min}$, respectively, in a controlled fashion.

Accepted 1st August 2013

DOI: $10.1039 / \mathrm{c} 3 \mathrm{dt} 51681 \mathrm{~d}$

www.rsc.org/dalton

\section{Introduction}

Poly(L-lactide) is a biopolymer used for a variety of specialty applications and as a bulk polymer. ${ }^{1}$ It is conveniently prepared through metal-mediated ring-opening polymerisation (ROP) of L-lactide. Following a decade of intense research,

${ }^{a}$ Organometallics: Materials and Catalysis, Institut des Sciences Chimiques de Rennes, UMR 6226 CNRS - University of Rennes 1, 35042 Cedex, Rennes, France. E-mail: yann.sarazin@univ-rennes1.fr

${ }^{b}$ Centre Régional des Mesures Physiques de l'Ouest, University of Rennes 1, 35042 Cedex, Rennes, France

${ }^{c}$ Centre de Diffractométrie des Rayons $X$, Institut des Sciences Chimiques de Rennes, UMR 6226 CNRS - University of Rennes 1, 35042 Cedex, Rennes, France

†Electronic supplementary information (ESI) available: VT NMR data and details of line-shape analysis for 2, 10 and $\left\{\mathrm{LO}^{2}\right\} \mathrm{SnCl}$; X-ray structure of $\left\{\mathrm{LO}^{3}\right\}_{2} \mathrm{~Pb} \cdot \mathrm{C}_{6} \mathrm{H}_{6}$. CCDC 942087-942099. For ESI and crystallographic data in CIF or other electronic format see DOI: $10.1039 / \mathrm{c} 3 \mathrm{dt} 51681 \mathrm{~d}$ great diversity now exists in the range of metal catalysts available for ROP reactions and related ring-opening pro-

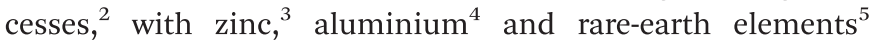
attracting the most interest. ${ }^{6}$ Industrial plants still rely on the use of simple tin(II) systems such as the versatile tin(II) bis(octanoate), ${ }^{7}$ an inexpensive and robust compound considered safe by the US Food and Drug Administration. Considering the popularity of this and other group 14 polymerisation catalysts, ${ }^{8}$ it is surprising that only a handful of germanium(II), ${ }^{9}$ $\operatorname{tin}(\mathrm{II})^{6 e-g, 10}$ or even lead(II) ${ }^{11}$ ROP catalysts have been reported. ${ }^{12}$ The canon of ligands employed to tailor ROP catalysts is virtually boundless, with prominent examples including bulky $\beta$-diketiminates or a range of phenolate (salen, salan, amino-phenolates, etc.) ligands. ${ }^{2-6}$ We embarked a few years ago upon the design of ROP catalysts built on somewhat unconventional metals supported by multidentate amino(ether)-phenolate ligands,,$^{6 j, l, 13}$ and explored ROP mechanisms 
using tin(II) complexes. ${ }^{6 g, 14}$ In the course of these investigations, we became involved in the coordination chemistry of tin(II) and related germanium(II) and lead(II) amino(ether)-phenolate complexes.

Phenolates are amenable to the tuning of their electronic and steric properties through modification of the substituents at the ortho and para positions of the aromatic ring, and this has led to a rich coordination chemistry. ${ }^{15}$ Yet, phenolates have seldom been applied to the stabilisation of singlet germylene, stannylene or plumbylene species, the heavier homologues of divalent carbenes. ${ }^{16}$ Unlike alkoxide $\mathrm{M}(\mathrm{OR})_{2}$ species that are often polymetallic $(\mathrm{R}=$ alkyl $),{ }^{17}$ sterically stabilised (and significantly less basic) homoleptic $\mathrm{M}(\mathrm{OAr})_{2}$ phenolate complexes are monomeric for $\mathrm{M}=\mathrm{Ge}$ and $\mathrm{Sn}\left(\mathrm{Ar}=2,6-t \mathrm{Bu}_{2}-4\right.$ $\mathrm{MeC}_{6} \mathrm{H}^{18}$ or 2,6- $\mathrm{Mes}_{2} \mathrm{C}_{6} \mathrm{H}_{3}{ }^{19}$ ). On the other hand, structural information for analogous plumbylenes is scarce, and it is just recently that the monomeric $\mathrm{Pb}\left(\mathrm{OC}_{6} \mathrm{H}_{3}-2,6-\left(2,6-\mathrm{iPr}_{2} \mathrm{C}_{6} \mathrm{H}_{3}\right)_{2}\right)_{2}$ has been authenticated in the solid state. ${ }^{20}$ The presence of side-arms containing heteroatoms $(\mathrm{N}, \mathrm{O})$ is a contributing factor towards the kinetic stability of three- or four-coordinate divalent homoleptic complexes formed through intramolecular coordination of the heteroatom(s) onto the metal centre. ${ }^{21}$ Tetracoordinated complexes $\left(\mathrm{N}^{\wedge} \mathrm{O}\right)_{2} \mathrm{M}$ supported by chelating dimethylaminoethoxide or 2,4,6-tris[(dimethylamino)methyl]phenolate ligands were found to be monomeric for $\mathrm{M}=\mathrm{Ge}$, $\mathrm{Sn},{ }^{22}$ but the solid-state structure of the lead(II) derivative was not available. ${ }^{23}$ The bidentate 2 -[(dimethylamino)methyl]phenolate yielded the monomeric germylene $\left(\mathrm{N}^{\wedge} \mathrm{O}\right)_{2} \mathrm{Ge}$, but the tin(II) and $\mathrm{Pb}(\mathrm{II})$ derivatives could not be structurally characterised; the parent heteroleptic complex $\left(\mathrm{N}^{\wedge} \mathrm{O}\right) \mathrm{SnCl}$ was dimeric, with $\mathrm{O}_{\text {phenolate }}$ atoms bridging two four-coordinate tin(II) centres. $^{24}$ Dimers are commonly observed for tin(II) when the germanium analogues are monomeric (lead congeners are seldom mentioned), e.g. in $\left\{\mathrm{M}\left(\mathrm{OCH}_{2} \mathrm{CH}_{2} \mathrm{NMe}_{2}\right)\left(\mathrm{N}\left(\mathrm{SiMe}_{3}\right)_{2}\right\}_{n}\right.$ $(\mathrm{M}=\mathrm{Ge}, n=1 ; \mathrm{M}=\mathrm{Sn}, n=2) .{ }^{25}$

We report here the synthesis and characterisation of monomeric, heteroleptic, 3-coordinate complexes of germanium(II), tin(II) and lead(II) incorporating multidentate, monoanionic amino(ether)-phenolate ligands, and their behaviour towards the ROP of L-lactide is introduced. Heterobimetallic complexes prepared by inclusion of alkali salts in the side-arm of these ligands containing an aza-crown-ether side-arm are also presented.

\section{Results and discussion}

\section{Stable, monomeric divalent metal amino-phenolates}

The heteroleptic amido complexes $\left\{\mathrm{LO}^{1}\right\} \mathrm{M}\left(\mathrm{N}\left(\mathrm{SiMe}_{3}\right)_{2}\right)(\mathrm{M}=\mathrm{Ge}$, 1; $\mathrm{Sn}, 5$; $\mathrm{Pb}, 9),\left\{\mathrm{LO}^{2}\right\} \mathrm{M}\left(\mathrm{N}\left(\mathrm{SiMe}_{3}\right)_{2}\right)(\mathrm{M}=\mathrm{Ge}, 2$; $\mathrm{Sn}, 6$; $\mathrm{Pb}, 10)$, $\left\{\mathrm{LO}^{3}\right\} \mathrm{M}\left(\mathrm{N}\left(\mathrm{SiMe}_{3}\right)_{2}\right)(\mathrm{M}=\mathrm{Ge}, 3 ; \mathrm{Sn}, 7 ; \mathrm{Pb}, \mathrm{11})$ and $\left\{\mathrm{LO}^{4}\right\} \mathrm{M}(\mathrm{N}-$ $\left.\left(\mathrm{SiMe}_{3}\right)_{2}\right)(\mathrm{M}=\mathrm{Sn}, \mathbf{8})$ where the metal is supported by a monoanionic chelating ligand chosen from an amino(ether)-phenolate (as in $\left\{\mathrm{LO}^{1}\right\}^{-}$), an amino-phenolate (as in $\left\{\mathrm{LO}^{2}\right\}^{-}$) or an amino(crown-ether)-phenolate (as in $\left\{\mathrm{LO}^{3}\right\}^{-}$and $\left\{\mathrm{LO}^{4}\right\}^{-}$) are available in good isolated yields upon protonolysis of the homoleptic divalent metal-amido precursors $\mathrm{M}\left(\mathrm{N}\left(\mathrm{SiMe}_{3}\right)_{2}\right)_{2}$ with the corresponding proteo-ligand $\left\{\mathrm{LO}^{i}\right\} \mathrm{H}$ in diethyl ether (Scheme 1). ${ }^{26}$<smiles>COCCN(CCOC)Cc1cc(Br)cc(Br)c1O</smiles>

$\left\{\mathrm{LO}^{1}\right\} \mathrm{H}$<smiles>CCN(CC)Cc1cc(Br)cc(Br)c1O</smiles>

$\left\{\mathrm{LO}^{2}\right\} \mathrm{H}$

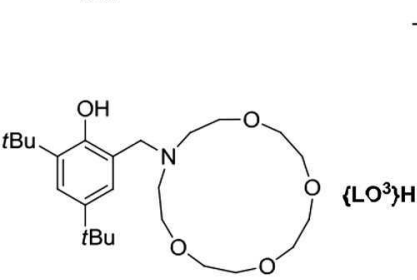

$\mathrm{M}\left(\mathrm{N}\left(\mathrm{SiMe}_{3}\right)_{2}\right)_{2}$ $\underset{-\mathrm{HN}\left(\mathrm{SiMe}_{3}\right)_{2}}{\mathrm{M}=\mathrm{Ge}, \mathrm{Sn}, \mathrm{Pb}}$

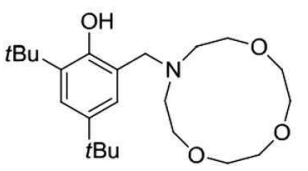

$\left\{\mathrm{LO}^{4}\right\} \mathrm{H}$<smiles>COCCN(CCOC)c1cc(C(C)(C)C)cc(C(C)(C)C)c1ON(C)N(C)C</smiles>

\section{$\left\{\mathrm{LO}^{-1}\right\} \mathrm{M}\left(\mathrm{N}\left(\mathrm{SiMe}_{3}\right)_{2}\right)$}

$\mathrm{M}=\mathrm{Ge} \quad 1 \quad 87 \%$

$\begin{array}{lll}\mathrm{Sn} & \mathbf{5} & 68 \% \\ \mathrm{~Pb} & \mathbf{9} & 84 \%\end{array}$<smiles>CCN(CC)Cc1cc(C(C)(C)C)cc(C(C)(C)C)c1ON(C)CC</smiles>

$\left\{\mathrm{LO}^{2}\right\} \mathrm{M}\left(\mathrm{N}\left(\mathrm{SiMe}_{3}\right)_{2}\right)$

$\begin{array}{rlr}\mathrm{M}=\mathrm{Ge} & \mathbf{2} & 47 \% \\ \mathrm{Sn} & \mathbf{6} & 76 \% \\ \mathrm{~Pb} & \mathbf{1 0} & 81 \%\end{array}$

$\left\{\mathrm{LO}^{3}\right\} \mathrm{M}\left(\mathrm{N}\left(\mathrm{SiMe}_{3}\right)_{2}\right)$<smiles>CN(C)COc1c(CN2CCOCCOCCOCCOCC2)cc(C(C)(C)C)cc1C(C)(C)C</smiles>

$\mathrm{M}=\mathrm{Ge} \quad 3 \quad 81 \%$

$\begin{array}{lll}\mathrm{Sn} & \mathbf{7} & 91 \% \\ \mathrm{~Pb} & \mathbf{1 1} & 90 \%\end{array}$<smiles>CCCCN1CCOCCOCCOCCN(Cc2cc(C(C)(C)C)cc(C(C)(C)C)c2ON(C)C)CCO1</smiles>

$\mathrm{M}=\mathrm{Ge} 4 \quad$ not pure

Sn $8 \quad 57 \%$

Scheme 1 Synthesis of the germylenes, stannylenes and plumbylenes 1-11; complexes 5-7 are taken from ref. $6 \mathrm{~g}$ and $14 \mathrm{a}$. 
The convenient protonolysis procedure offered better yields than one-pot salt metathesis reactions. ${ }^{27}$ For instance, the germylene 3 was isolated after a tedious work-up in only $46 \%$ yield from the one-pot reaction of $\left\{\mathrm{LO}^{3}\right\} \mathrm{H}, \mathrm{GeCl}_{2}$.dioxane and two equiv. of $\mathrm{KN}\left(\mathrm{SiMe}_{3}\right)_{2}$. The stoichiometric reaction of $\left\{\mathrm{LO}^{3}\right\}$ $\mathrm{GeCl}$ (a colourless solid accessible upon treatment of $\mathrm{GeCl}_{2}$. dioxane with fresh $\left.\left\{\mathrm{LO}^{3}\right\} \mathrm{K}\right)$ with $\mathrm{KN}\left(\mathrm{SiMe}_{3}\right)_{2}$ brought no improvement.

Similarly, $\left\{\mathrm{LO}^{3}\right\} \mathrm{SnCl}$ was obtained from $\mathrm{SnCl}_{2}$ and $\left\{\mathrm{LO}^{3}\right\} \mathrm{K}$ but its reaction with $\mathrm{KN}\left(\mathrm{SiMe}_{3}\right)_{2}$ only led to partial formation of 7 ( $c a .60 \%)$ together with unidentified species. Complexes 1-3, 5-10, $\left\{\mathrm{LO}^{3}\right\} \mathrm{GeCl}$ and $\left\{\mathrm{LO}^{3}\right\} \mathrm{SnCl}$ were isolated as analytically pure colourless solids. The plumbylene $\mathbf{1 1}$ could not be obtained entirely free of the homoleptic $\left\{\mathrm{LO}^{3}\right\}_{2} \mathrm{~Pb}$ (a complex otherwise cleanly synthesized by reaction of $\mathrm{Pb}\left(\mathrm{N}\left(\mathrm{SiMe}_{3}\right)_{2}\right)_{2}$ with 2 equiv. of $\left.\left\{\mathrm{LO}^{3}\right\} \mathrm{H}\right)$. No reliable synthesis to the germylene 4 could be designed, as intractable mixtures were repeatedly recovered. ${ }^{28}$ All complexes are soluble in aromatic hydrocarbons and ethers, and are sparingly so in petroleum ether; they are fully soluble in dichloromethane and do not react with this solvent through acid-base reaction. ${ }^{29}$ All are stable in aromatic solvents as indicated by ${ }^{1} \mathrm{H}$ NMR monitoring, bar the kinetically labile 11 which rapidly evolves to generate $\left\{\mathrm{LO}^{3}\right\}_{2} \mathrm{~Pb}$ and $\mathrm{Pb}\left(\mathrm{N}\left(\mathrm{SiMe}_{3}\right)_{2}\right)_{2}$. The complexes were characterised by $1 \mathrm{D}$ and $2 \mathrm{D}$ solution NMR methods, including ${ }^{29} \mathrm{Si}\left\{{ }^{1} \mathrm{H}\right\}$ and, where relevant, ${ }^{119} \mathrm{Sn}\left\{{ }^{1} \mathrm{H}\right\}$ and ${ }^{207} \mathrm{~Pb}\left\{{ }^{1} \mathrm{H}\right\}$ NMR spectroscopy. Except for 2, 6 and 10 incorporating the simplest amino-phenolate $\left\{\mathrm{LO}^{2}\right\}^{-}$, the ${ }^{1} \mathrm{H}$ NMR spectra of all complexes in toluene- $d_{8}$ or benzene- $d_{6}$ showed high levels of fluxionality at $298 \mathrm{~K}$, which hindered detailed assignment of the resonances for the side-arm hydrogen atoms; low temperature NMR in toluene- $d_{8}$ provided little help.

In the ${ }^{1} \mathrm{H}$ NMR spectra recorded in benzene- $d_{6}$ or toluene$d_{8}$ at $298 \mathrm{~K}$ for the amido complexes $2,6,{ }^{14 a} 10$ and for $\left\{\mathrm{LO}^{2}\right\}$ $\mathrm{SnCl},{ }^{14 a}$ the two $\mathrm{CH}_{2} \mathrm{CH}_{3}$ groups on the side-arm nitrogen atom are not equivalent. In $\mathbf{1 0}$ (Fig. 1, top), the four $\mathrm{N}\left(\mathrm{CH}_{2} \mathrm{CH}_{3}\right)_{2}$ methylene hydrogens are magnetically distinct, each being characterised by its own broad resonance $\left(\delta^{1} \mathrm{H}=\right.$ $3.28,2.84,2.50$ and $2.39 \mathrm{ppm})$, whereas two broad signals exchanging slowly at $298 \mathrm{~K}$ are found for the two $\mathrm{N}\left(\mathrm{CH}_{2} \mathrm{CH}_{3}\right)_{2}$ methyl groups (centred on $\delta^{1} \mathrm{H}=0.74$ and $0.57 \mathrm{ppm}$ ); this is indicative of overall $C_{1}$ symmetry, which was corroborated by crystallographic studies (vide infra). The fluxionality in $\mathbf{1 0}$ could be frozen at low temperature: sharp resonances were detected for all hydrogen atoms in the ${ }^{1} \mathrm{H}$ NMR spectrum recorded at $263 \mathrm{~K}$ (Fig. 1, bottom), and they were readily assigned. At $368 \mathrm{~K}$, the $\mathrm{ArCH}_{2}, \mathrm{NCH}_{2} \mathrm{CH}_{3}$ and $\mathrm{NCH}_{2} \mathrm{CH}_{3}$ moieties in $\mathbf{1 0}$ each gives rise to a single resonance and the ${ }^{1} \mathrm{H}$ NMR spectrum agrees with $p$ seudo $C_{\mathrm{s}}$ symmetry.

Manual NMR line-shape analysis was performed for $\mathbf{1 0}$ in the temperature range $263-363 \mathrm{~K}$, using a $0.1 \mathrm{M}$ solution in toluene- $d_{8}$. All changes observed in this range were reversible on return to $298 \mathrm{~K}$. An overlay of the $0.30-1.80 \mathrm{ppm}$ region of the ${ }^{1} \mathrm{H}$ NMR spectra $(400.13 \mathrm{MHz})$ is displayed in Fig. 2. Coalescence of the two resonances attributed to the two nonequivalent methyl groups in the $\mathrm{N}\left(\mathrm{CH}_{2} \mathrm{CH}_{3}\right)_{2}$ moiety (two

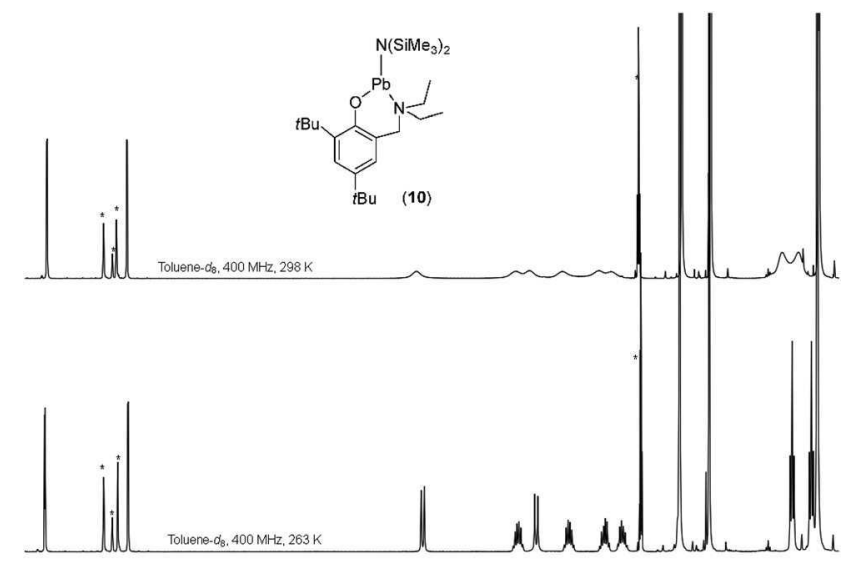

ig. $1{ }^{1} \mathrm{H}$ NMR spectra $\left(400.13 \mathrm{MHz}\right.$, toluene- $\left.d_{8}\right)$ for $\left\{\mathrm{LO}^{2}\right\} \mathrm{Pb}\left(\mathrm{N}\left(\mathrm{SiMe}_{3}\right)_{2}\right)(10)$ recorded at $263 \mathrm{~K}$ (bottom) and $298 \mathrm{~K}$ (top). Solvent resonances are identified by *.

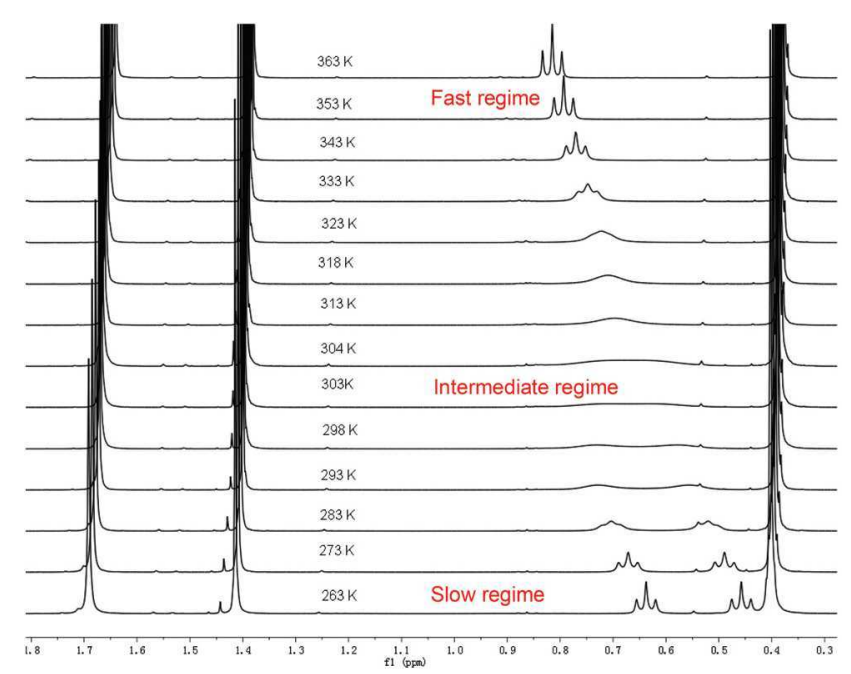

Fig. 2 Stack of the $0.30-1.80$ ppm region of the ${ }^{1} \mathrm{H}$ NMR spectra $(400.13 \mathrm{MHz}$, toluene- $\left.d_{8}\right)$ of $\left\{\mathrm{LO}^{2}\right\} \mathrm{Pb}\left(\mathrm{N}\left(\mathrm{SiMe}_{3}\right)_{2}\right)$ (10) recorded in the temperature range 263-363 K.

triplets centred on $\delta=0.64$ and $0.46 \mathrm{ppm}$ in the slow regime at $263 \mathrm{~K}$ ) was observed at $T_{\mathrm{c}}=304 \mathrm{~K}$.

Using $\delta \nu=71 \mathrm{~Hz}$ (determined at $263 \mathrm{~K}$ ) leads to an estimate of $\Delta G^{\ddagger}=14.6 \mathrm{kcal} \mathrm{mol}^{-1}$ for the free energy of activation associated with the exchange between the ethyl groups. The corresponding enthalpy and entropy of activation $\Delta H^{\ddagger}=$ 14.8(0.5) kcal mol${ }^{-1}$ and $\Delta S^{\ddagger}=+0.7(1.6) \mathrm{cal} \mathrm{K}^{-1} \mathrm{~mol}^{-1}$ were estimated by Eyring treatment of exchange rates determined by line-shape analysis (Fig. 3). The variation of entropy associated with this process, which is assumed to proceed via dissociation-recoordination of the amino moiety, is surprisingly small. Arrhenius analysis led to $E_{\mathrm{a}}=15.5(0.5) \mathrm{kcal} \mathrm{mol}^{-1}$. The equation

$$
E_{\mathrm{a}}=\Delta H^{\ddagger}+m R T
$$




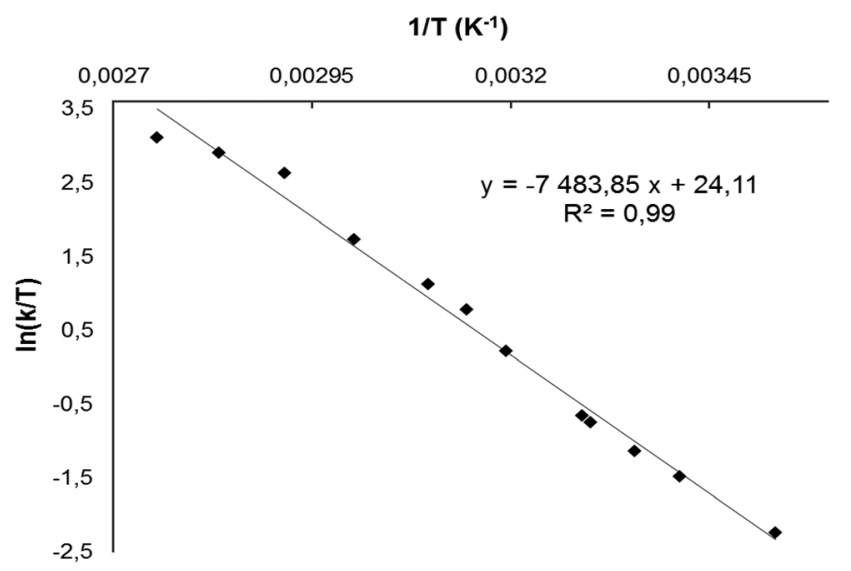

Fig. 3 Eyring treatment of exchange rates determined by line-shape analysis ( $T=263-363 \mathrm{~K}$ ) for the dynamic behaviour of $\mathrm{NCH}_{2} \mathrm{CH}_{3}$ hydrogens in $\left\{\mathrm{LO}^{2}\right\} \mathrm{Pb}$ $\left(\mathrm{N}\left(\mathrm{SiMe}_{3}\right)_{2}\right)(\mathbf{1 0})$

where $m$ is the order of the reaction corresponding to the fluxional changes, gives a kinetic order of 1 for this process for $T_{\mathrm{c}}=304 \mathrm{~K}$. A single resonance at $c a .+2100 \mathrm{ppm}$ is seen in the ${ }^{207} \mathrm{~Pb}\left\{{ }^{1} \mathrm{H}\right\}$ NMR spectra of $\mathbf{1 0}$ in this temperature range, which confirms the existence of a single environment.

Eyring and Arrhenius analyses were performed for $\left\{\mathrm{LO}^{2}\right\}$ $\mathrm{SnCl}$ (in the range 298-368 K; $T_{\mathrm{c}}=322 \mathrm{~K}$ ), but treatment of the data for $2\left(T=233-363 \mathrm{~K} ; T_{\mathrm{c}}=318 \mathrm{~K}\right)$ could not be performed as relevant parameters $\left(\delta \nu, \Delta \nu_{1 / 2}^{e}\right.$ and $\Delta \nu_{1 / 2}^{0}$, see the ESI $\left.\dagger\right)$ could not be determined accurately. Comparative data for 2, 6, 10 and $\left\{\mathrm{LO}^{2}\right\} \mathrm{SnCl}$ are collected in Table 1; they all are commensurate. Although performed over a limited temperature range, the data for $\left\{\mathrm{LO}^{2}\right\} \mathrm{SnCl}$ compare with those reported for $\mathbf{6}$, confirming the reliability of the procedure. Identical phenomena, equivalent to a dynamic racemization process at a pseudochiral 3-coordinate metal centre, must be at work in both cases.

Heteronuclear NMR data recorded at $298 \mathrm{~K}$ in aromatic solvents are presented in Table 2 . The ${ }^{29} \mathrm{Si}\left\{{ }^{1} \mathrm{H}\right\}$ chemical shifts for 1-11 all fall in the same narrow range; the slight shift towards high fields on moving from germylenes to stannylenes and plumbylenes is consistent with increasing ionicity of the corresponding $\mathrm{M}-\mathrm{N}_{\text {amido }}$ bond. The ${ }^{119} \mathrm{Sn}\left\{{ }^{1} \mathrm{H}\right\}$ chemical shift $\left({ }^{119} \mathrm{Sn}: I=1 / 2\right.$, natural abundance $=8.6 \%$, receptivity relative to $\left.{ }^{1} \mathrm{H}=4.4 \times 10^{-3}\right)$ for the new stannylene $8(-49.9 \mathrm{ppm})$ is nearly identical to those measured for $5-7$, and is diagnostic of a 3-coordinate, monomeric tin(II) centre. ${ }^{14 a}$ Since ${ }^{207} \mathrm{~Pb}\left\{{ }^{1} \mathrm{H}\right\}$ chemical shifts for lead(II) compounds spread in the range -6000 to $+6000 \mathrm{ppm}\left({ }^{207} \mathrm{~Pb}: I=1 / 2\right.$, natural abundance $=$ $22.1 \%$, receptivity relative to ${ }^{1} \mathrm{H}=2.1 \times 10^{-3}$ ), similar resonances detected for the plumbylenes 9-11 (singlets between +2000 and $+2150 \mathrm{ppm}$ ) testify to near-identical chemical and magnetic environments for the three metal centres. Since the amino-phenolate ligand in $\mathbf{1 0}$ is devoid of a side-arm oxygen atom, we concluded that the tethered $\mathrm{O}_{\text {side-arm }}$ atoms in $\mathbf{9}$ and 11 do not interact with the metal in solution. This postulate is in agreement with structural information obtained from XRD crystallography, and ${ }^{207} \mathrm{~Pb}\left\{{ }^{1} \mathrm{H}\right\}$ chemical shifts in the range

Table 1 Summary of Eyring and Arrhenius analyses for fluxional processes in the $\mathrm{N}\left(\mathrm{CH}_{2} \mathrm{CH}_{3}\right)_{2}$ fragments of $\mathbf{2}, \mathbf{6}, \mathbf{1 0}$ and $\left\{\mathrm{LO}^{2}\right\} \mathrm{SnCl}$

\begin{tabular}{|c|c|c|c|c|c|c|c|}
\hline Complex & & $T_{\mathrm{c}}^{b}\left({ }^{\circ} \mathrm{C}\right)$ & $\delta \nu^{c}(\mathrm{~Hz})$ & $E_{\mathrm{a}}\left(\mathrm{kcal} \mathrm{mol}^{-1}\right)$ & $\Delta G^{\ddagger}\left(\mathrm{kcal} \mathrm{mol}^{-1}\right)$ & $\Delta H^{\dagger}\left(\mathrm{kcal} \mathrm{mol}^{-1}\right)$ & $\Delta S^{\ddagger}\left(\mathrm{cal} \mathrm{K}^{-1} \mathrm{~mol}^{-1}\right)$ \\
\hline$\left\{\mathrm{LO}^{2}\right\} \mathrm{Ge}\left(\mathrm{N}\left(\mathrm{SiMe}_{3}\right)_{2}\right)$ & (2) & 318 & $\mathrm{n} / \mathrm{a}^{d}$ & $\mathrm{n} / \mathrm{a}^{d}$ & +16.3 & $\mathrm{n} / \mathrm{a}^{d}$ & $\mathrm{n} / \mathrm{a}^{d}$ \\
\hline$\left\{\mathrm{LO}^{2}\right\} \mathrm{Sn}\left(\mathrm{N}\left(\mathrm{SiMe}_{3}\right)_{2}\right)$ & (6) & 318 & 28 & $+13.6(0.3)$ & +16.0 & $+13.0(0.3)$ & $-9.6(1.0)$ \\
\hline$\left\{\mathrm{LO}^{2}\right\} \mathrm{Pb}\left(\mathrm{N}\left(\mathrm{SiMe}_{3}\right)_{2}\right)$ & (10) & 304 & 71 & $+15.5(0.5)$ & +14.6 & $+14.8(0.5)$ & $+0.7(1.6)$ \\
\hline$\left\{\mathrm{LO}^{2}\right\} \mathrm{SnCl}$ & & 322 & 62 & $+13.2(0.1)$ & +16.4 & $+12.5(0.1)$ & $-9.8(10.3)$ \\
\hline
\end{tabular}

${ }^{a}$ NMR data recorded in toluene- $d_{8}$; data for 6 taken from ref. $14 a .{ }^{b}$ Coalescence temperature. ${ }^{c}$ Difference of frequencies for the separated methyl groups at the lowest available temperature. ${ }^{d}$ Could not be determined accurately.

Table 2 NMR data for 1-11, $\left\{\mathrm{LO}^{3}\right\}_{2} \mathrm{~Pb},\left\{\mathrm{LO}^{2}\right\} \mathrm{SnCl}$ and $\left\{\mathrm{LO}^{3}\right\} \mathrm{SnCl}$

\begin{tabular}{|c|c|c|c|c|c|c|}
\hline \multicolumn{2}{|l|}{ Complex } & \multirow{2}{*}{$\begin{array}{l}\text { Solvent } \\
\text { Toluene- } d_{8}\end{array}$} & \multirow{2}{*}{$\frac{{ }^{29} \mathrm{Si}\left\{{ }^{1} \mathrm{H}\right\}(\mathrm{ppm})}{0.41}$} & \multirow{2}{*}{${ }^{119} \mathrm{Sn}\left\{{ }^{1} \mathrm{H}\right\}(\mathrm{ppm})$} & \multirow{2}{*}{${ }_{-}^{{ }^{207} \mathrm{~Pb}\left\{{ }^{1} \mathrm{H}\right\}(\mathrm{ppm})}$} & \multirow{2}{*}{$\begin{array}{l}\text { Reference } \\
\text { This work }\end{array}$} \\
\hline$\left\{\mathrm{LO}^{1}\right\} \mathrm{Ge}\left(\mathrm{N}\left(\mathrm{SiMe}_{3}\right)_{2}\right)$ & (1) & & & & & \\
\hline$\left\{\mathrm{LO}^{2}\right\} \mathrm{Ge}\left(\mathrm{N}\left(\mathrm{SiMe}_{3}\right)_{2}\right)$ & (2) & Toluene- $d_{8}$ & 0.06 & - & - & This work \\
\hline$\left\{\mathrm{LO}^{1}\right\} \mathrm{Sn}\left(\mathrm{N}\left(\mathrm{SiMe}_{3}\right)_{2}\right)$ & (5) & Toluene- $d_{8}$ & -0.66 & -63.8 & - & $14 a$ \\
\hline$\left\{\mathrm{LO}^{2}\right\} \mathrm{Sn}\left(\mathrm{N}\left(\mathrm{SiMe}_{3}\right)_{2}\right)$ & (6) & Benzene- $d_{6}$ & -0.63 & -62.8 & - & $14 a$ \\
\hline$\left\{\mathrm{LO}^{3}\right\} \mathrm{Sn}\left(\mathrm{N}\left(\mathrm{SiMe}_{3}\right)_{2}\right)$ & (7) & Benzene- $d_{6}$ & -0.49 & -55.0 & - & $6 g$ \\
\hline$\left\{\mathrm{LO}^{4}\right\} \mathrm{Sn}\left(\mathrm{N}\left(\mathrm{SiMe}_{3}\right)_{2}\right)$ & (8) & Toluene- $d_{8}$ & -0.34 & -49.9 & - & This work \\
\hline$\left\{\mathrm{LO}^{2}\right\} \mathrm{SnCl}$ & & Toluene- $d_{8}$ & - & -218.1 & - & $14 a$ \\
\hline$\left\{\mathrm{LO}^{3}\right\} \mathrm{SnCl}$ & & Toluene- $d_{8}$ & - & -385.0 & - & This work \\
\hline$\left\{\mathrm{LO}^{1}\right\} \mathrm{Pb}\left(\mathrm{N}\left(\mathrm{SiMe}_{3}\right)_{2}\right)$ & (9) & Toluene- $d_{8}$ & -3.35 & - & 2007 & This work \\
\hline$\left\{\mathrm{LO}^{2}\right\} \mathrm{Pb}\left(\mathrm{N}\left(\mathrm{SiMe}_{3}\right)_{2}\right)$ & (10) & Toluene- $d_{8}$ & -2.35 & - & 2135 & This work \\
\hline$\left\{\mathrm{LO}^{3}\right\} \mathrm{Pb}\left(\mathrm{N}\left(\mathrm{SiMe}_{3}\right)_{2}\right)$ & (11) & Benzene- $d_{6}$ & -3.29 & - & 2027 & This work \\
\hline$\left\{\mathrm{LO}^{3}\right\}_{2} \mathrm{~Pb}$ & & Benzene- $d_{6}$ & - & - & -367 & This work \\
\hline
\end{tabular}

${ }^{a}$ NMR data were recorded at $25^{\circ} \mathrm{C}$. 
+2000 to $+2200 \mathrm{ppm}$ are thus indicative of 3-coordinate, monomeric amino-phenolate lead(II) amides. By comparison, the homoleptic $\left\{\mathrm{LO}^{3}\right\}_{2} \mathrm{~Pb}$, featuring a 4-coordinate metal in the solid state $(\mathrm{ESI}+)$, exhibits a shielded resonance at $\delta_{207 \mathrm{~Pb}}=$ $-367 \mathrm{ppm}$.

The molecular structures of the germylenes 1-3 and $\left\{\mathrm{LO}^{3}\right\}$ $\mathrm{GeCl}$, stannylenes $\mathbf{8}$ and $\left\{\mathrm{LO}^{3}\right\} \mathrm{SnCl}$, and plumbylenes 9-11 were determined by X-ray diffraction measurements (Fig. 4-12). Independently of the identity of the metal, all these complexes are monomeric in the solid state and feature 3-coordinate metal atoms. All amino(ether)-phenolate ligands lead to the formation of a 6-membered metallacycle through sole coordination of the $\mathrm{O}_{\text {phenolate }}$ and $\mathrm{N}_{\text {side-arm }}$ atoms as also observed for the amino-phenolate $\left\{\mathrm{LO}^{1}\right\}^{-}$; where they could potentially occur, interactions between $\mathrm{O}_{\text {side-arm }}$ atoms and the metal were never detected. The environment about the metal is otherwise completed by $\mathrm{Cl}^{-}$or the bulky amide $\mathrm{N}\left(\mathrm{SiMe}_{3}\right)_{2}{ }^{-}$.

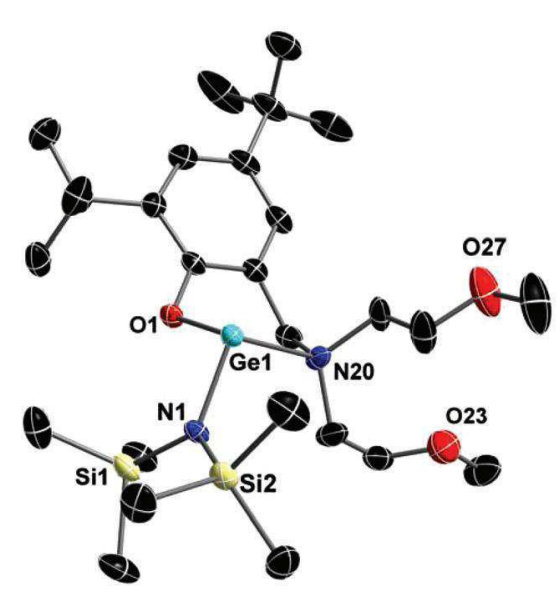

Fig. 4 ORTEP diagram of the molecular structure of $\left\{\mathrm{LO}^{1}\right\} \mathrm{Ge}\left(\mathrm{N}\left(\mathrm{SiMe}_{3}\right)_{2}\right)$ (1) Ellipsoids are drawn at the $50 \%$ probability level. Hydrogen atoms are omitted for clarity. Selected bond lengths $(\AA)$ and angles $\left({ }^{\circ}\right)$ : $\mathrm{Ge}(1)-\mathrm{O}(1)=1.876(2)$, $\mathrm{Ge}(1)-\mathrm{N}(1)=1.901(2), \mathrm{Ge}(1)-\mathrm{N}(20)=2.319(3) ; \mathrm{O}(1)-\mathrm{Ge}(1)-\mathrm{N}(1)=96.35(9)$, $\mathrm{O}(1)-\mathrm{Ge}(1)-\mathrm{N}(20)=88.33(9), \mathrm{N}(1)-\mathrm{Ge}(1)-\mathrm{N}(20)=100.4(1)$.

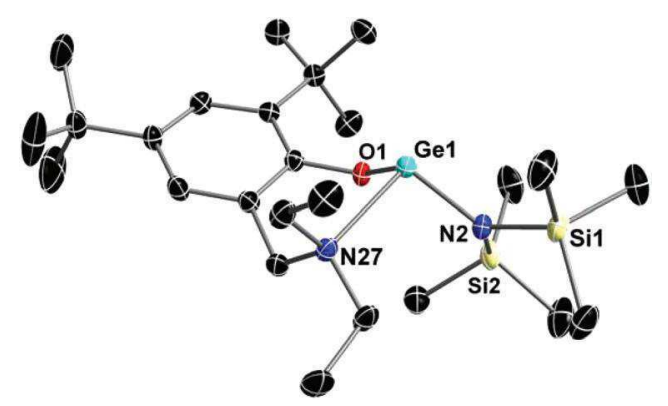

Fig. 5 ORTEP diagram of the molecular structure of $\left\{\mathrm{LO}^{2}\right\} \mathrm{Ge}\left(\mathrm{N}\left(\mathrm{SiMe}_{3}\right)_{2}\right)$ (2) Ellipsoids are drawn at the $50 \%$ probability level. Hydrogen atoms are omitted for clarity. Selected bond lengths $(\AA \AA)$ and angles $\left({ }^{\circ}\right)$ : $\mathrm{Ge}(1)-\mathrm{O}(1)=1.872(1)$ $\mathrm{Ge}(1)-\mathrm{N}(2)=1.907(1), \mathrm{Ge}(1)-\mathrm{N}(27)=2.294(1) ; \mathrm{O}(1)-\mathrm{Ge}(1)-\mathrm{N}(2)=94.52(6)$, $\mathrm{O}(1)-\mathrm{Ge}(1)-\mathrm{N}(27)=90.22(6), \mathrm{N}(2)-\mathrm{Ge}(1)-\mathrm{N}(27)=100.60(6)$.

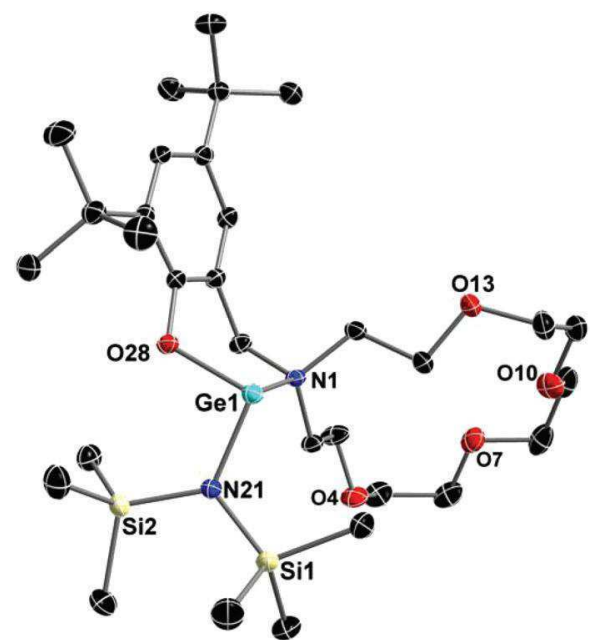

Fig. 6 ORTEP diagram of the molecular structure of $\left\{\mathrm{LO}^{3}\right\} \mathrm{Ge}\left(\mathrm{N}\left(\mathrm{SiMe}_{3}\right)_{2}\right)$ (3). Ellipsoids are drawn at the $50 \%$ probability level. Hydrogen atoms are omitted for clarity. Selected bond lengths $(\AA)$ and angles $\left({ }^{\circ}\right)$ : $\mathrm{Ge}(1)-\mathrm{O}(28)=1.891(1)$, $\mathrm{Ge}(1)-\mathrm{N}(21)=1.913(1), \mathrm{Ge}(1)-\mathrm{N}(1)=2.318(1) ; \mathrm{O}(28)-\mathrm{Ge}(1)-\mathrm{N}(21)=95.72(5)$, $\mathrm{O}(28)-\mathrm{Ge}(1)-\mathrm{N}(1)=90.07(4), \mathrm{N}(21)-\mathrm{Ge}(1)-\mathrm{N}(1)=100.14(5)$.

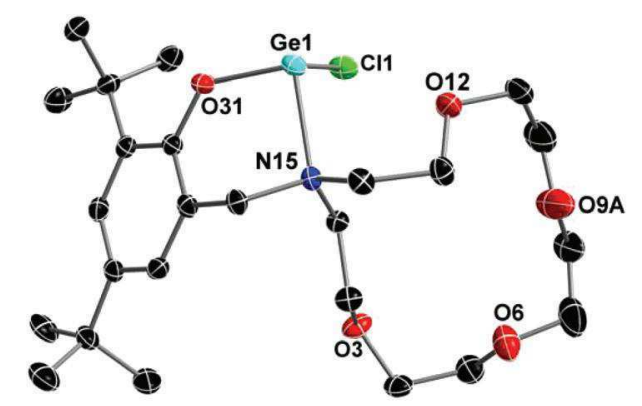

Fig. 7 ORTEP diagram of the molecular structure of $\left\{\mathrm{LO}^{3}\right\} \mathrm{GeCl}$. Ellipsoids are drawn at the $50 \%$ probability level. Hydrogen atoms are omitted for clarity. Only the main component of the disordered segment in the heterocycle side-arm (viz O9A) is represented. Selected bond lengths $(\AA)$ and angles $\left({ }^{\circ}\right)$ : Ge(1)-(O3)1 = $1.860(2), \mathrm{Ge}(1)-\mathrm{N}(15)=2.189(2), \mathrm{Ge}(1)-\mathrm{Cl}(1)=2.301(7) ; \mathrm{O}(31)-\mathrm{Ge}(1)-\mathrm{N}(15)=$ $92.42(7), \mathrm{O}(31)-\mathrm{Ge}(1)-\mathrm{Cl}(1)=95.72(6), \mathrm{N}(15)-\mathrm{Ge}(1)-\mathrm{Cl}(1)=97.95(6)$.

Pertinent metric parameters for these complexes as well as 5-7 are displayed in Table 3.

Except for the $\mathrm{M}$-heteroatom interatomic distances which increase regularly with the size of the metal (effective ionic radii for a coordination number of $6: \mathrm{Ge}^{\mathrm{II}}, 0.73 \AA$ $; \mathrm{Sn}^{\mathrm{II}}$, unspecified; $\mathrm{Pb}^{\mathrm{II}}, 1.19 \AA$; empirical atomic radius: $\mathrm{Ge}^{\mathrm{II}}, 1.25 \AA$; $\mathrm{Sn}^{\mathrm{II}}, 1.45 \AA$; $\left.\mathrm{Pb}^{\mathrm{II}}, 1.80 \AA\right),{ }^{30}$ the geometric features of all complexes are very similar (Table 3 ). All heteroatom-metal-heteroatom angles are fairly close to $90^{\circ}$. This suggests very limited or absence of hybridization between $s$ and $p$ valence orbitals and, for a given metal, the character of the orbital for the lone pair of electrons is essentially $\mathrm{ns}^{2} .^{31}$ All bond lengths fall in the expected range for such compounds. For a given ligand framework, there is no notable modification of the structural features for $\mathrm{Ge} / \mathrm{Sn} / \mathrm{Pb}$ complexes beyond the normal extension of the three $\mathbf{M}$-heteroatom distances. For each family built on 


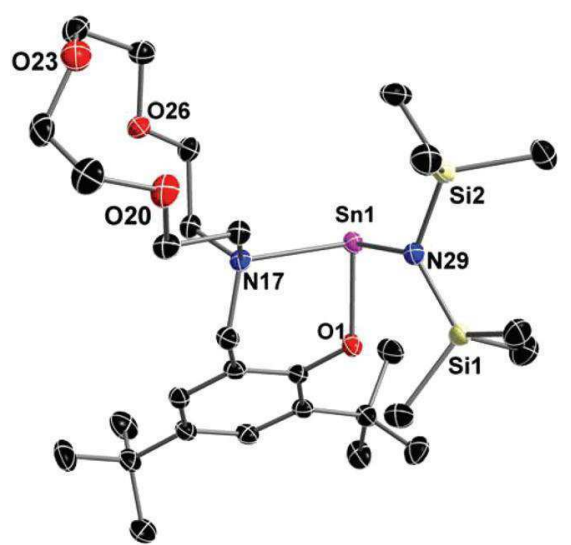

Fig. 8 ORTEP diagram of the molecular structure of $\left.\left\{\mathrm{LO}^{4}\right\} \mathrm{Sn}\left(\mathrm{N}_{(\mathrm{SiMe}}\right)_{2}\right)$ (8). Ellipsoids are drawn at the $50 \%$ probability level. Hydrogen atoms are omitted for clarity. Selected bond lengths $(\AA)$ and angles $\left({ }^{\circ}\right)$ : $\operatorname{Sn}(1)-O(1)=2.064(1)$, $\operatorname{Sn}(1)-N(29)=2.115(1), \operatorname{Sn}(1)-N(17)=2.419(1) ; O(1)-S n(1)-N(29)=93.78(5)$ $\mathrm{O}(1)-\mathrm{Sn}(1)-\mathrm{N}(17)=86.55(4), \mathrm{N}(29)-\mathrm{Sn}(1)-\mathrm{N}(17)=95.62(5)$.

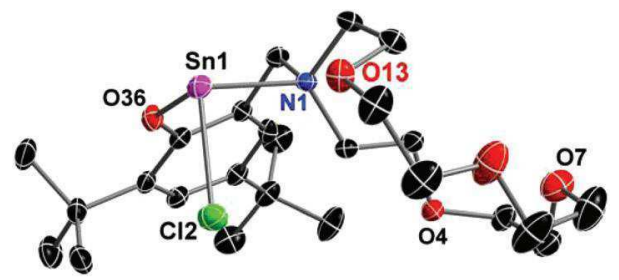

Fig. 9 ORTEP diagram of the molecular structure of $\left\{\mathrm{LO}^{3}\right\} \mathrm{SnCl}$. Ellipsoids are drawn at the $50 \%$ probability level. Hydrogen atoms are omitted for clarity. Selected bond lengths $(\AA)$ and angles $\left({ }^{\circ}\right)$ : $\operatorname{Sn}(1)-O(36)=2.072(2), \operatorname{Sn}(1)-N(1)=$ $2.357(2), \mathrm{Sn}(1)-\mathrm{Cl}(2)=2.462(1) ; \mathrm{O}(36)-\mathrm{Sn}(1)-\mathrm{N}(1)=86.17(6), \mathrm{O}(36)-\mathrm{Sn}(1)-\mathrm{Cl}(2)$ $=92.96(5), N(1)-S n(1)-C \mid(2)=97.50(5)$

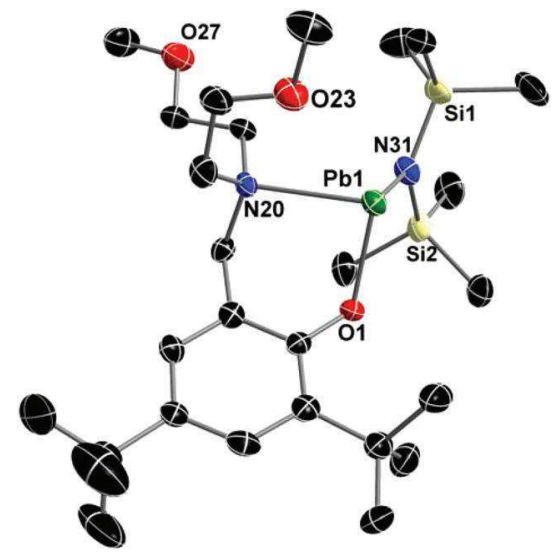

Fig. 10 ORTEP diagram of the molecular structure of $\left\{\mathrm{LO}^{1}\right\} \mathrm{Pb}\left(\mathrm{N}\left(\mathrm{SiMe}_{3}\right)_{2}\right)$ (9) Ellipsoids are drawn at the $50 \%$ probability level. Hydrogen atoms are omitted for clarity. Selected bond lengths $(\AA)$ and angles $\left({ }^{\circ}\right)$ : $\mathrm{Pb}(1)-\mathrm{O}(1)=2.220(4)$, $\mathrm{Pb}(1)-\mathrm{N}(20)=2.537(5), \mathrm{Pb}(1)-\mathrm{N}(31)=2.243(5) ; \mathrm{O}(1)-\mathrm{Pb}(1)-\mathrm{N}(31)=93.7(2)$, $\mathrm{O}(1)-\mathrm{Pb}(1)-\mathrm{N}(20)=83.9(2), \mathrm{N}(31)-\mathrm{Pb}(1)-\mathrm{N}(20)=95.8(2)$.

a same metal, bond distances and angles vary little between complexes with the exception of the $\mathrm{N}_{\text {amine }}-\mathrm{Sn}-\mathrm{Cl}$ angle for $\left\{\mathrm{LO}^{3}\right\} \mathrm{SnCl}$ (entry $10,97.5^{\circ}$ ) and $\left\{\mathrm{LO}^{2}\right\} \mathrm{SnCl}$ (entry 9, 89.5 $)$.

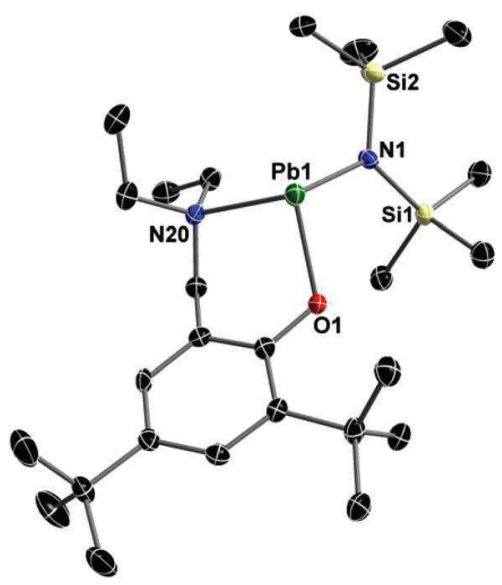

Fig. 11 ORTEP diagram of the molecular structure of $\left\{\mathrm{LO}^{2}\right\} \mathrm{Pb}\left(\mathrm{N}\left(\mathrm{SiMe}_{3}\right)_{2}\right)(10)$. Ellipsoids are drawn at the $50 \%$ probability level. Hydrogen atoms are omitted for clarity. Selected bond lengths $(\AA)$ and angles $\left({ }^{\circ}\right)$ : $\mathrm{Pb}(1)-\mathrm{O}(1)=2.186(2)$, $\mathrm{Pb}(1)-\mathrm{N}(1)=2.218(3), \mathrm{Pb}(1)-\mathrm{N}(20)=2.536(3) ; \mathrm{O}(1)-\mathrm{Pb}(1)-\mathrm{N}(1)=92.61(9)$ ， $\mathrm{O}(1)-\mathrm{Pb}(1)-\mathrm{N}(20)=83.97(9), \mathrm{N}(1)-\mathrm{Pb}(1)-\mathrm{N}(20)=97.9(1)$.

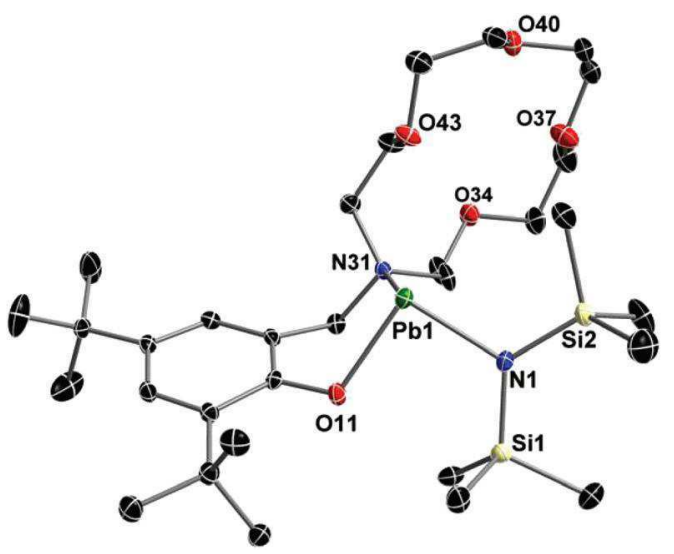

Fig. 12 ORTEP diagram of the molecular structure of $\left\{\mathrm{LO}^{3}\right\} \mathrm{Pb}\left(\mathrm{N}\left(\mathrm{SiMe}_{3}\right)_{2}\right)$ (11). Ellipsoids are drawn at the $50 \%$ probability level. Hydrogen atoms are omitted for clarity. Selected bond lengths $(\AA)$ and angles $\left({ }^{\circ}\right)$ : $\mathrm{Pb}(1)-\mathrm{O}(11)=2.227(2)$, $\mathrm{Pb}(1)-\mathrm{N}(1)=2.237(2), \mathrm{Pb}(1)-\mathrm{N}(31)=2.543(2) ; \mathrm{O}(11)-\mathrm{Pb}(1)-\mathrm{N}(1)=91.51(8)$, $\mathrm{O}(11)-\mathrm{Pb}(1)-\mathrm{N}(31)=84.68(8), \mathrm{N}(1)-\mathrm{Pb}(1)-\mathrm{N}(31)=97.97(8)$.

The latter complex is rather peculiar, as the $\mathrm{N}_{\text {amine }}-\mathrm{Sn}-\mathrm{Cl}$ angle is also much smaller than the corresponding $\mathrm{N}_{\mathrm{amine}}-\mathrm{Sn}-$ $\mathrm{N}_{\mathrm{amine}}$ angle found in the congeneric amido complex 6 (entry $\left.6,97.7^{\circ}\right)$, whereas no such discrepancy was found between the analogous pair of complexes $\left\{\mathrm{LO}^{3}\right\} \mathrm{SnCl}$ and 7. Comparison of entries 3 and 4 emphasizes that the nature of the $\mathrm{X}^{-}$co-ligand, where $\mathrm{X}^{-}$is either $\mathrm{Cl}^{-}$or $\mathrm{N}\left(\mathrm{SiMe}_{3}\right)_{2}{ }^{-}$, should bear little influence on the geometric patterns around the metal.

\section{Heterobimetallic inclusion complexes}

The structural features of the family $\left\{\mathrm{LO}^{3}\right\} \mathrm{M}\left(\mathrm{N}\left(\mathrm{SiMe}_{3}\right)_{2}(\mathrm{M}=\right.$ $\mathrm{Ge}, 3 ; \mathrm{Sn}, 7 ; \mathrm{Pb}, 11$ ) where the amino(ether)-phenolate incorporates the aza-15-crown-5 tether are of particular interest. Because none of the $\mathrm{O}_{\text {side-arm }}$ atoms is coordinated onto the metal, we postulated that they could be employed for further 
Table 3 Relevant metric parameters for 1-3, 5-11, $\left\{\mathrm{LO}^{2}\right\} \mathrm{SnCl}$ and $\left\{\mathrm{LO}^{3}\right\} \mathrm{SnCl}$

\begin{tabular}{|c|c|c|c|c|c|c|c|c|c|}
\hline Entry & Complex & & $\mathrm{M}-\mathrm{O}_{\text {phenolate }}(\AA)$ & $M-X(\AA)$ & $\mathrm{M}-\mathrm{N}_{\text {amine }}(\AA)$ & $\begin{array}{l}\mathrm{O}_{\text {phenolate }}{ }^{-} \\
\mathrm{M}^{-} \mathrm{N}_{\text {amine }}\left({ }^{\circ}\right)\end{array}$ & $\begin{array}{l}\mathrm{O}_{\text {phenolate }}{ }^{-} \\
\mathrm{M}-\mathrm{X}\left({ }^{\circ}\right)\end{array}$ & $\begin{array}{l}\mathrm{N}_{\text {amine }}^{-} \\
\mathrm{M}-\mathrm{X}\left({ }^{\circ}\right)\end{array}$ & Reference \\
\hline 1 & $\left\{\mathrm{LO}^{1}\right\} \mathrm{Ge}\left(\mathrm{N}\left(\mathrm{SiMe}_{3}\right)_{2}\right)$ & (1) & $1.876(2)$ & $1.901(2)$ & $2.319(3)$ & $88.33(9)$ & $96.35(9)$ & $100.4(1)$ & This work \\
\hline 2 & $\left\{\mathrm{LO}^{2}\right\} \mathrm{Ge}\left(\mathrm{N}\left(\mathrm{SiMe}_{3}\right)_{2}\right)$ & (2) & $1.872(1)$ & $1.907(1)$ & $2.294(1)$ & $90.22(6)$ & $94.52(6)$ & $100.60(6)$ & This work \\
\hline 3 & $\left\{\mathrm{LO}^{3}\right\} \mathrm{Ge}\left(\mathrm{N}\left(\mathrm{SiMe}_{3}\right)_{2}\right)$ & (3) & 1.891(1) & $1.913(1)$ & $2.318(1)$ & $90.07(4)$ & $95.72(5)$ & $100.14(5)$ & This work \\
\hline 4 & $\left\{\mathrm{LO}^{3}\right\} \mathrm{GeCl}$ & & $1.860(2)$ & $2.301(7)$ & $2.189(2)$ & $92.42(7)$ & $95.72(6)$ & $97.95(6)$ & This work \\
\hline 5 & $\left\{\mathrm{LO}^{1}\right\} \mathrm{Sn}\left(\mathrm{N}\left(\mathrm{SiMe}_{3}\right)_{2}\right)$ & (5) & $2.077(1)$ & $2.128(2)$ & $2.469(2)$ & $85.43(5)$ & $91.24(5)$ & $95.95(6)$ & $14 a$ \\
\hline 6 & $\left\{\mathrm{LO}^{2}\right\} \mathrm{Sn}\left(\mathrm{N}\left(\mathrm{SiMe}_{3}\right)_{2}\right)$ & (6) & $2.066(3)$ & $2.102(4)$ & $2.435(3)$ & $86.6(1)$ & $94.0(1)$ & $97.7(1)$ & $14 a$ \\
\hline 7 & $\left\{\mathrm{LO}^{3}\right\} \mathrm{Sn}\left(\mathrm{N}\left(\mathrm{SiMe}_{3}\right)_{2}\right)$ & (7) & $2.074(1)$ & $2.112(1)$ & $2.437(1)$ & $86.08(4)$ & $94.06(4)$ & $96.78(4)$ & $6 g$ \\
\hline 8 & $\left\{\mathrm{LO}^{4}\right\} \mathrm{Sn}\left(\mathrm{N}\left(\mathrm{SiMe}_{3}\right)_{2}\right)$ & (8) & $2.064(1)$ & $2.115(1)$ & $2.419(1)$ & $86.55(4)$ & $93.78(5)$ & $95.62(5)$ & This work \\
\hline 9 & $\left\{\mathrm{LO}^{2}\right\} \mathrm{SnCl}$ & & $2.036(2)$ & $2.506(7)$ & $2.393(2)$ & $86.18(7)$ & $93.79(6)$ & $89.46(5)$ & $14 a$ \\
\hline 10 & $\left\{\mathrm{LO}^{3}\right\} \mathrm{SnCl}$ & & $2.072(2)$ & $2.468(1)$ & $2.357(2)$ & $86.17(6)$ & $92.96(5)$ & $97.50(5)$ & This work \\
\hline 11 & $\left\{\mathrm{LO}^{1}\right\} \mathrm{Pb}\left(\mathrm{N}\left(\mathrm{SiMe}_{3}\right)_{2}\right)$ & (9) & $2.220(4)$ & $2.243(5)$ & $2.537(5)$ & $83.9(2)$ & $93.7(2)$ & $95.8(2)$ & This work \\
\hline 12 & $\left\{\mathrm{LO}^{2}\right\} \mathrm{Pb}\left(\mathrm{N}\left(\mathrm{SiMe}_{3}\right)_{2}\right)$ & (10) & $2.186(2)$ & $2.218(3)$ & $2.536(3)$ & $83.97(9)$ & $92.61(9)$ & $97.9(1)$ & This work \\
\hline 13 & $\left\{\mathrm{LO}^{3}\right\} \mathrm{Pb}\left(\mathrm{N}\left(\mathrm{SiMe}_{3}\right)_{2}\right)$ & (11) & $2.227(2)$ & $2.237(2)$ & $2.543(2)$ & $84.68(8)$ & $91.51(8)$ & $97.97(8)$ & This work \\
\hline
\end{tabular}

${ }^{a} \mathrm{M}=\mathrm{Ge}^{\mathrm{II}}, \mathrm{Sn}^{\mathrm{II}}$ or $\mathrm{Pb}^{\mathrm{II}} ; \mathrm{X}=\mathrm{Cl}$ or $\mathrm{N}\left(\mathrm{SiMe}_{3}\right)_{2}$.

coordination chemistry involving an additional metallic centre. The high affinity of (aza-)crown ethers for cationic metals has been demonstrated, and can be exploited to design ion sensors acting through selective ligation of metal ions. ${ }^{32}$ Macrocycles containing 5 heteroatoms such as 15 -crown- 5 and 1-aza-15-crown-5 are ideally suited to the binding of the small $\mathrm{Li}^{+}$and $\mathrm{Na}^{+}$alkali ions, ${ }^{32 b}$ and we reasoned that salts of these metals could be combined with 3, 7 and/or 11 to prepare heterobimetallic complexes through inclusion of the hard cation in the anchored macrocycle of the $\left\{\mathrm{LO}^{3}\right\}^{-}$ligand. A related approach was implemented by Jurkschat and co-workers, who provided elegant spectroscopic evidence for the formation of tin(Iv)-halide bimetallic species upon addition of various alkali halides to solutions of their bis(crown ether)-substituted organostannanes $\mathrm{X}_{2} \mathrm{Sn}\left(\mathrm{CH}_{2}-[16] \text {-crown-5 }\right)_{2}(\mathrm{X}=\mathrm{Br}, \mathrm{I}) .{ }^{33}$ Also, Batten and co-workers have just reported manganese- or cuprous-potassium heterobimetallic coordination polymers using a functionalised diaza-18-crown-6 ligand possessing pendant $p$-pyridylpyrazole side-arms. ${ }^{34}$

In a preliminary reaction, the proteo-ligand $\left\{\mathrm{LO}^{3}\right\} \mathrm{H}$ (a colourless oil $)^{35}$ was reacted with LiOTf in diethyl ether (Scheme 2). The ${ }^{1} \mathrm{H}$ and ${ }^{13} \mathrm{C}\left\{{ }^{1} \mathrm{H}\right\}$ NMR data for the white solid $\left(\left\{\mathrm{LO}^{3}\right\} \mathrm{H} \cdot \mathrm{LiOTf}\right)$ obtained quantitatively after evaporation were different from those for $\left\{\mathrm{LO}^{3}\right\} \mathrm{H}$, suggesting that the lithium cation was ligated by the macrocyclic heteroatoms. This was confirmed by X-ray diffraction crystallography, which shows the alkali metal to sit in the pocket formed by the four $\mathrm{O}_{\text {side-arm }}$ atoms and to be further coordinated by one oxygen atom from the triflate counter-ion, whereas the $\mathrm{N}_{\text {side-arm }}$ atom is not involved in the coordination sphere of the metal (Fig. 13). The geometry about the metal constitutes a distorted square pyramidal $(\tau=0.36),{ }^{36}$ with the tightly bound $\mathrm{O}_{\text {triflate }}$ atom occupying the apical position and the $\mathrm{O}_{\text {side-arm }}$ atoms being more remote from the metal.

As the molecular structures of 3 and $\left\{\mathrm{LO}^{3}\right\} \mathrm{H} \cdot \mathrm{LiOTf}$ offered the structural features required for the formation of a heterobimetallic complex, the reaction of the latter with $\mathrm{Ge}\left(\mathrm{N}\left(\mathrm{SiMe}_{3}\right)_{2}\right)_{2}$ was attempted, but it failed to yield the mixed $\mathrm{Ge}^{\mathrm{II}}-\mathrm{Li}$ species (Scheme 2). Instead, the desired complex 3.LiOTf was obtained by equimolar reaction between the germylene 3 and lithium triflate. It is a colourless solid soluble in ethers and aromatic hydrocarbons, but insoluble in light petroleum. It was characterised by NMR spectroscopy and X-ray diffraction crystallography, but the presence of residual $\left\{\mathrm{LO}^{3}\right\} \mathrm{H} \cdot \mathrm{LiOTf}$ could not be avoided, which precluded good combustion analysis.

The molecular solid state structure of 3.LiOTf is remarkable (Fig. 14). It can be divided into two fragments which virtually do not interact with each other: one pertaining to the aminophenolate Ge(II) amide, and the other relating to the a polyether-LiOTf moiety. The triflate anion tightly bound to the Li atom and the bulky amido group $\mathrm{N}\left(\mathrm{SiMe}_{3}\right)_{2}{ }^{-}$are located in trans position with respect to the plane defined by the five heteroatoms of the macrocycle, so that they impart minimal steric congestion to the coordination spheres of either of the two metals. All bonding patterns and metric parameters for the 3-coordinate $\mathrm{Ge}^{\mathrm{II}}$ centre in 3.LiOTf match closely those described for 3 alone, whereas those measured around the 5 -coordinate $\mathrm{Li}$ centre $(\tau=0.33)^{36}$ are very similar to those found for $\left\{\mathrm{LO}^{3}\right\} \mathrm{H} \cdot \mathrm{LiOTf}$. The large $\mathrm{Ge}^{\mathrm{II}} \cdots \mathrm{Li}$ distance $(5.85 \AA)$ rules out the existence of metallophilic interactions.

The heterobimetallic $\mathrm{Sn}^{\mathrm{II}}$-Li complex 7.LiOTf was also prepared by reaction of 7 and lithium triflate, since the reaction of $\left\{\mathrm{LO}^{3}\right\} \mathrm{H} \cdot \mathrm{LiOTf}$ and $\mathrm{Sn}\left(\mathrm{N}\left(\mathrm{SiMe}_{3}\right)_{2}\right)_{2}$ proved unsuccessful (Scheme 2). The solid state structure of the $\mathrm{Sn}^{\mathrm{II}}-\mathrm{Li}$ bimetallic complex 7-LiOTf is depicted in Fig. 15. All attempts to obtain the lead(II) analogue of 3.LiOTf and 7-LiOTf failed: the kinetic lability of $\mathbf{1 1}$ and its contamination by $\left\{\mathrm{LO}^{3}\right\}_{2} \mathrm{~Pb}$ (vide supra) preclude its use as an efficient precursor, while no reaction took place between $\left\{\mathrm{LO}^{3}\right\} \mathrm{H} \cdot \mathrm{LiOTf}$ and $\mathrm{Pb}\left(\mathrm{N}\left(\mathrm{SiMe}_{3}\right)_{2}\right)_{2}$.

The molecular structure of 7-LiOTf resembles closely that of 3-LiOTf, with a 3-coordinate tin(II) centre and a 5-coordinate lithium atom in a square pyramidal environment $(\tau=0.21){ }^{36}$ The geometries and interatomic distances around the $\mathrm{Sn}^{\mathrm{II}}$ and $\mathrm{Li}$ atoms in 7-LiOTf match those found in the parent compounds 7 and $\left\{\mathrm{LO}^{3}\right\} \mathrm{H} \cdot \mathrm{LiOTf}$, even if $\mathrm{Li}-\mathrm{O}_{\text {side-arm }}$ and $\mathrm{Li}-\mathrm{O}_{\text {triflate }}$ bond lengths in the latter compound are a little longer than in the heterobimetallic complex. There is no $\mathrm{Sn}^{\mathrm{II}} \cdot . \mathrm{Li}$ interaction on account of the long intermetallic distance (6.06 ̊). 
<smiles>C[Ga](C)Oc1c(CN2CCOCCOCCOCCOCC2)cc(C(C)(C)C)cc1C(C)(C)C</smiles>

(3)<smiles>CC(C)(C)c1cc(CN2CCOCCOCCOCCOCC2)c(O)c(C(C)(C)C)c1</smiles>

$\mathrm{LiCF}_{3} \mathrm{SO}_{3}$<smiles>CC(F)(F)Cc1cc(C(C)(C)C)cc(C(C)(C)C)c1O[SnH]1CCOCCOCCOCCOCC1</smiles>

(7)

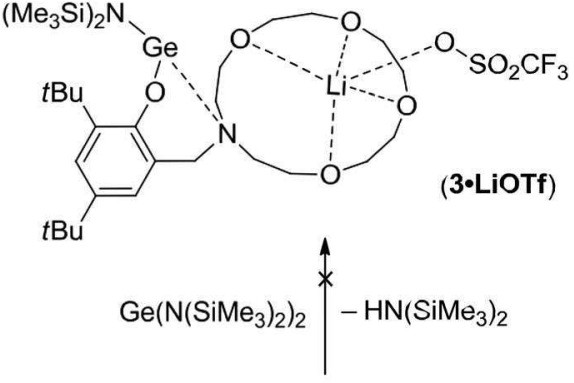<smiles>CC(C)(C)c1cc(CN2CCOC3(OOC(F)(F)F)OCCOCC3(OOC(F)(F)F)[I-]2)c(O)c(C(C)(C)C)c1</smiles><smiles>CC(C)C(C)(C)N(C)C</smiles>

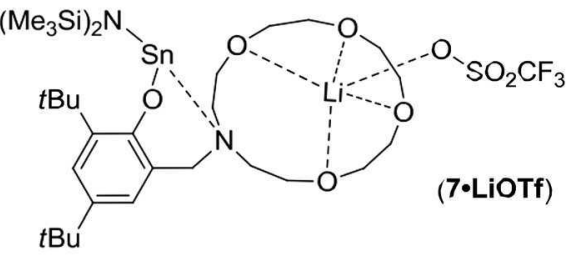

Scheme 2 Synthesis of heterobimetallic compounds.

On the whole, in the solid state, the inclusion of the small alkali metal bears no impact on the coordination sphere about the p-block metal in these amino(crown-ether)-phenolate complexes, be it with germanium(II) or the larger tin(II). This is also likely so in solution, as indicated by heteronuclear NMR spectroscopy. ${ }^{37}$ The ${ }^{119} \mathrm{Sn}\left\{{ }^{1} \mathrm{H}\right\}$ data recorded for 7 and 7.LiOTf $\left(\delta_{\mathrm{Sn}}=-55.0\right.$ and $-45.8 \mathrm{ppm}$, respectively) in dichloromethane$d_{2}$ (owing to limited solubility of the latter in aromatic hydrocarbons) are nearly identical; the corresponding ${ }^{29} \mathrm{Si}\left\{{ }^{1} \mathrm{H}\right\}$ chemical shifts are also very similar $\left(\delta_{\mathrm{Si}}=-0.75\right.$ and $-0.31 \mathrm{ppm})$, and the ${ }^{7} \mathrm{Li}\left\{{ }^{1} \mathrm{H}\right\}$ chemical shift for 7.LiOTf $\left(\delta_{\mathrm{Li}}=\right.$ $-0.56 \mathrm{ppm})$ matched that for the tin-free $\left\{\mathrm{LO}^{3}\right\} \mathrm{H} \cdot \mathrm{LiOTf}\left(\delta_{\mathrm{Li}}=\right.$ $-0.84 \mathrm{ppm})$ in this solvent. Moreover, in benzene- $d_{6}$ or toluene- $d_{8}$, the ${ }^{7} \mathrm{Li}\left\{{ }^{1} \mathrm{H}\right\}\left(\delta_{\mathrm{Li}}=-0.74 \mathrm{ppm}\right)$ and ${ }^{29} \mathrm{Si}\left\{{ }^{1} \mathrm{H}\right\}\left(\delta_{\mathrm{Si}}=\right.$ $+0.70 \mathrm{ppm}$ ) resonances for 3.LiOTf are comparable to those for $\left\{\mathrm{LO}^{3}\right\} \mathrm{H} \cdot \operatorname{LiOTf}\left(\delta_{\mathrm{Li}}=-0.96 \mathrm{ppm}\right)$ and $3\left(\delta_{\mathrm{Si}}=2.37 \mathrm{ppm}\right)$, respectively.

Although the size of the macrocyclic side-arm is in principle suited to the binding of sodium ions, ${ }^{32}$ attempts at such insertions using sodium triflate or the $\left[\mathrm{Na}\left(\mathrm{OEt}_{2}\right)_{4}\right]^{+} \cdot\left[\mathrm{H}_{2} \mathrm{~N}-\right.$ $\left.\left\{\mathrm{B}\left(\mathrm{C}_{6} \mathrm{~F}_{5}\right)_{3}\right\}_{2}\right]^{-}$loose ion pair $^{38}$ failed to deliver heterobimetallic complexes with either 3 or 7 . Efforts to prepare bimetallic species starting from complex $\mathbf{8}$ where the macrocycle contains only four heteroatoms also met with no success, although NMR data showed that $\left\{\mathrm{LO}^{4}\right\} \mathrm{H} \cdot \mathrm{LiOTf}$ could be synthesised. The ability of the highly chelating $\left\{\mathrm{LO}^{3}\right\}^{-}$to yield polymetallic alkali species had previously been highlighted through ready formation of $\left\{\mathrm{LO}^{3}\right\} \mathrm{Li} \cdot \mathrm{LiN}\left(\mathrm{SiMe}_{2} \mathrm{H}\right)_{2}{ }^{13 i}$ and $\left[\left\{\mathrm{LO}^{3}\right\} \mathrm{K} \cdot \mathrm{KN}-\right.$ $\left.\left(\mathrm{SiMe}_{2} \mathrm{H}\right)_{2}\right],{ }^{13 d}$ although the challenges overcome for the preparation of 3.LiOTf and 7.LiOTf were greater than those associated with these homobimetallic alkali complexes. We have in the past failed to prepare the $\mathrm{Zn}-\mathrm{Li}$ equivalent to 3-LiOTf and 7.LiOTf, perhaps because the ionic nature of the $\mathrm{Zn}-\mathrm{O}$ and $\mathrm{Li}-\mathrm{O}$ bonds led to deleterious redistribution reactions. The ability of the tethered side-arm in $\left\{\mathrm{LO}^{3}\right\}^{-}$to perfectly host $\mathrm{Li}^{+}$salts also precludes the use of $\left\{\mathrm{LO}^{3}\right\} \mathrm{Li}$ species for salt metathesis reactions, as intractable mixtures are always obtained from such reactions; this is why $\left\{\mathrm{LO}^{3}\right\} \mathrm{K}$ was used instead to obtain $\left\{\mathrm{LO}^{3}\right\} \mathrm{GeCl}$ and $\left\{\mathrm{LO}^{3}\right\} \mathrm{SnCl}$ (vide supra).

\section{Ring-opening polymerisation studies}

The performance of complexes 1-3 and 5-10 in the catalysis of the immortal ring-opening polymerisation (iROP) of L-lactide (L-LA) or racemic-lactide (rac-LA) upon addition of $\mathrm{iPrOH}$ was probed (Scheme 3). ${ }^{2 c, 39}$ The heterobimetallic 3.LiOTf and 7-LioTf were also assessed to gauge the influence of the 


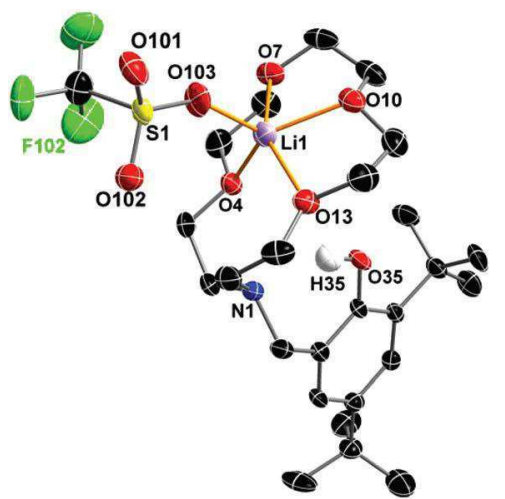

Fig. 13 ORTEP diagram of the molecular structure of $\left\{L^{3}\right\} H$ LIOTf. Ellipsoids are drawn at the $50 \%$ probability level. Hydrogen atoms are omitted for clarity. Selected bond lengths $(\AA)$ and angles $\left({ }^{\circ}\right): \mathrm{Li}(1)-\mathrm{O}(103)=1.940(5), \mathrm{Li}(1)-\mathrm{O}(10)=$ 2.105(5), $\mathrm{Li}(1)-\mathrm{O}(7)=2.105(5), \mathrm{Li}(1)-\mathrm{O}(13)=2.138(5), \mathrm{Li}(1)-\mathrm{O}(4)=2.159(5)$; $\mathrm{O}(103)-\mathrm{Li}(1)-\mathrm{O}(10)=119.5(3), \mathrm{O}(103)-\mathrm{Li}(1)-\mathrm{O}(7)=100.3(2), \mathrm{O}(10)-\mathrm{Li}(1)-\mathrm{O}(7)=$ 77.86(18), O(103)-Li(1)-O(13) = 105.5(2), O(10)-Li(1)-O(13) = 77.46(19), O(7)$\mathrm{Li}(1)-\mathrm{O}(13)=150.7(3), \mathrm{O}(103)-\mathrm{Li}(1)-\mathrm{O}(4)=109.5(3), \mathrm{O}(10)-\mathrm{Li}(1)-\mathrm{O}(4)=$ 128.9(2), O(7)- $\mathrm{Li}(1)-\mathrm{O}(4)=80.27(18), \mathrm{O}(13)-\mathrm{Li}(1)-\mathrm{O}(4)=103.5(2)$.

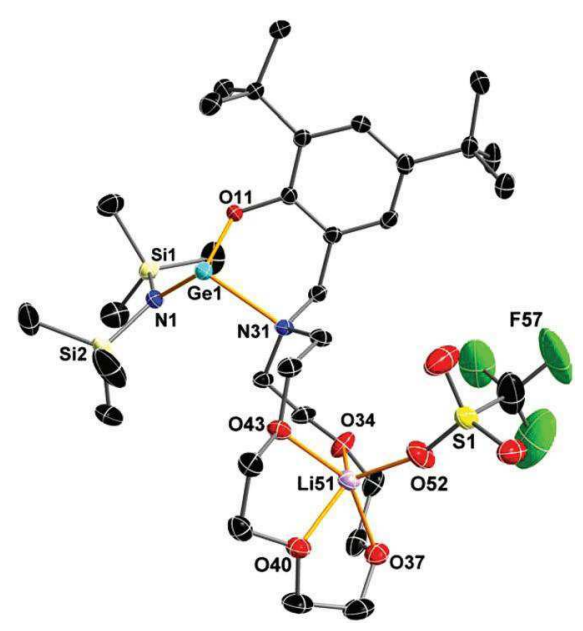

Fig. 14 ORTEP diagram of the molecular structure of 3.LiOTf. Ellipsoids are drawn at the $50 \%$ probability level. Hydrogen atoms are omitted for clarity. Selected bond lengths $(\AA)$ and angles $\left({ }^{\circ}\right)$ : Ge(1)-O(11) = 1.871(1), Ge(1)-N(1) = 1.902(1), $\mathrm{Ge}(1)-\mathrm{N}(31)=2.335(1), \mathrm{O}(34)-\mathrm{Li}(51)=2.081(3), \mathrm{O}(37)-\mathrm{Li}(51)=$ 2.096(3), O(40)-Li(51) = 2.034(3), O(43)-Li(51) = 2.081(3), Li(51)-O(52) = 1.885(3); O(11)-Ge(1)-N(1) = 96.23(6), O(11)-Ge(1)-N(31) = 89.49(5), N(1)$\mathrm{Ge}(1)-\mathrm{N}(31)=99.04(6), \mathrm{O}(52)-\mathrm{Li}(51)-\mathrm{O}(40)=117.82(16), \mathrm{O}(52)-\mathrm{Li}(51)-\mathrm{O}(43)=$ 105.45(15), O(40) $-\mathrm{Li}(51)-\mathrm{O}(43)=78.32(12), \mathrm{O}(52)-\mathrm{Li}(51)-\mathrm{O}(34)=111.26(16)$, $\mathrm{O}(40)-\mathrm{Li}(51)-\mathrm{O}(34)=130.15(16), \mathrm{O}(43)-\mathrm{Li}(51)-\mathrm{O}(34)=97.17(14), \mathrm{O}(52)-$ $\mathrm{Li}(51)-\mathrm{O}(37)=102.34(16), \mathrm{O}(40)-\mathrm{Li}(51)-\mathrm{O}(37)=78.46(12), \mathrm{O}(43)-\mathrm{Li}(51)-$ $\mathrm{O}(37)=149.81(17), \mathrm{O}(34)-\mathrm{Li}(51)-\mathrm{O}(37)=83.41(12)$.

additional alkali metal, but the heteroleptic chloro derivatives were not interrogated because (i) their behaviour in the presence of (excess) alcohol is often erratic, and (ii) chloride is a very poor initiating group. Complex 11, which could not be obtained free of impurity, was also excluded from this screening. Reactions were typically performed in toluene at $60-100{ }^{\circ} \mathrm{C}$, using $500-1000$ equiv. of lactide and $10-25$ equiv. of alcohol vs. metal, and [lactide $]_{0}=2.0 \mathrm{M}$.

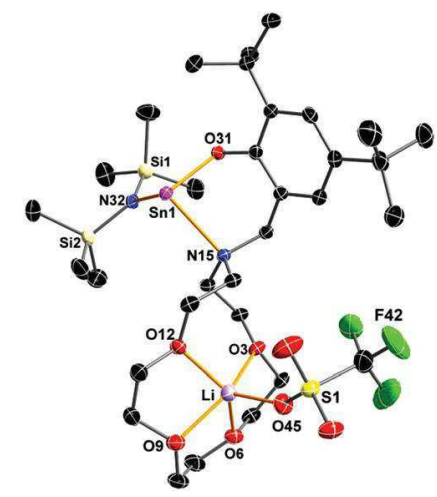

Fig. 15 ORTEP diagram of the molecular structure of 7.LiOTf. Ellipsoids are drawn at the $50 \%$ probability level. Hydrogen atoms are omitted for clarity. Selected bond lengths $(\AA)$ and angles $\left(^{\circ}\right)$ : $\mathrm{Sn}(1)-\mathrm{O}(31)=2.0880(15), \operatorname{Sn}(1)-\mathrm{N}(32)$ $=2.1137(17), \mathrm{Sn}(1)-\mathrm{N}(15)=2.4860(17), \mathrm{Li}-\mathrm{O}(45)=1.893(4), \mathrm{Li}-\mathrm{O}(6)=2.025(4)$, $\mathrm{Li}-\mathrm{O}(12)=2.040(4), \mathrm{Li}-\mathrm{O}(9)=2.111(4), \mathrm{Li}-\mathrm{O}(3)=2.142(4) ; \mathrm{O}(31)-\mathrm{Sn}(1)-\mathrm{N}(32)=$ $96.86(6), \mathrm{O}(31)-\mathrm{Sn}(1)-\mathrm{N}(15)=84.41(6), \mathrm{N}(32)-\mathrm{Sn}(1)-\mathrm{N}(15)=99.47(6), \mathrm{O}(45)-$ $\mathrm{Li}-\mathrm{O}(6)=105.55(19), \mathrm{O}(45)-\mathrm{Li}-\mathrm{O}(12)=117.6(2), \mathrm{O}(6)-\mathrm{Li}-\mathrm{O}(12)=136.29(19)$, $\mathrm{O}(45)-\mathrm{Li}-\mathrm{O}(9)=107.82(19), \mathrm{O}(6)-\mathrm{Li}-\mathrm{O}(9)=79.19(15), \mathrm{O}(12)-\mathrm{Li}-\mathrm{O}(9)=$ 81.14(15), O(45)-Li-O(3) = 100.42(18), O(6)-Li-O(3) = 81.44(15), O(12)-Li$\mathrm{O}(3)=96.91(17), \mathrm{O}(9)-\mathrm{Li}-\mathrm{O}(3)=149.11(19)$.

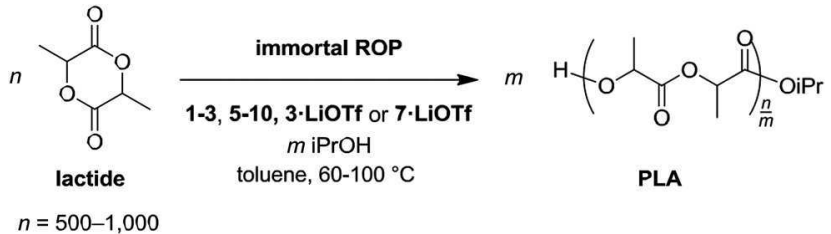

Scheme 3

Several trends emerge rapidly from examination of the data presented in Table 4. In combination with iPrOH (10 equiv.), which acts both as a co-catalyst and a chain transfer agent, all tested complexes afford binary catalytic systems for ROP reactions presenting a high level of control over the macromolecular features (qualitatively measured by the good agreement between theoretical and experimentally determined (by SEC or NMR) molecular weights, and by the narrow polydispersity index $\left.M_{\mathrm{w}} / M_{\mathrm{n}}\right)$. Yet, the activity changes drastically with the size of the metal, as reaction rates increase with metal size according to $\mathrm{Ge}^{\mathrm{II}} \ll \mathrm{Sn}^{\mathrm{II}} \ll \mathrm{Pb}^{\mathrm{II}}$. Where germylenes require $6 \mathrm{~h}$ to convert only partly 500 equiv. of monomer at $100{ }^{\circ} \mathrm{C}$ (entries 1-3), nearly full conversion is achieved within $3 \mathrm{~h}$ at $60^{\circ} \mathrm{C}$ with the stannylenes (entries 7-10) while the plumbylene 9 fully converts 1000 equiv. of monomer in as little as $3 \mathrm{~min}$ at $60^{\circ} \mathrm{C}$ (entry 12). Increase of ROP catalytic activity with metal size has already been reported for alkaline-earth metals, ${ }^{6 j, l, 41}$ but this cannot be extended to all groups, as for instance such a relationship cannot be drawn for metals of groups 4 and $13 .^{2 a, g, h}$ In this series of compounds, for a given metal, the identity of the ligand bears limited influence, if any, on the final outcome of the polymerisation; compare for instance entries $1-3,5-8$ and 16-17, an observation which has already been discussed elsewhere in detail in the case of tin(II) 
Table 4 iROP of lactide promoted by 1-3, 5-10, 3-LiOTf or 7.LiOTf in association with iPrOH

\begin{tabular}{|c|c|c|c|c|c|c|c|c|c|c|c|}
\hline Entry & Precat. & LA & $\begin{array}{l}{[\mathrm{LA}]_{0} /[\text { Precat }]_{0} /} \\
{[\mathrm{iPrOH}]_{0}}\end{array}$ & $\begin{array}{l}T^{\mathrm{re}} \\
\left({ }^{\circ} \mathrm{C}\right)\end{array}$ & $\begin{array}{l}\text { Time } \\
(\mathrm{min})\end{array}$ & $\begin{array}{l}\text { Yield }^{b} \\
(\%)\end{array}$ & $\begin{array}{l}M_{\mathrm{n}, \text { theo }}{ }^{c} \\
\left(\mathrm{~g} \mathrm{~mol}^{-1}\right)\end{array}$ & $\begin{array}{l}M_{\mathrm{n}, \mathrm{SEC}}{ }^{d} \\
\left(\mathrm{~g} \mathrm{~mol}^{-1}\right)\end{array}$ & $\begin{array}{l}M_{\mathrm{w}} / \\
M_{\mathrm{n}}{ }^{d}\end{array}$ & $\begin{array}{l}\left.M_{\mathrm{n}, \mathrm{NMR}^{e}}{ }^{-1}\right) \\
\left(\mathrm{g} \mathrm{mol}^{-1}\right)\end{array}$ & $P_{\mathrm{r}}^{f}$ \\
\hline 1 & 1 & $\mathrm{~L}^{-}$ & $500: 1: 10$ & 100 & 360 & 74 & 5400 & 7100 & 1.21 & 4800 & \\
\hline 2 & 2 & $\mathrm{~L}^{-}$ & $500: 1: 10$ & 100 & 360 & 82 & 6000 & 8100 & 1.13 & 5200 & \\
\hline 3 & 3 & $\mathrm{~L}^{-}$ & $500: 1: 10$ & 100 & 360 & 35 & 2600 & 3600 & 1.09 & 2900 & \\
\hline 4 & 3 & $\mathrm{~L}^{-}$ & $1000: 1: 10$ & 100 & 360 & 15 & 2200 & 2900 & 1.07 & 2700 & \\
\hline 5 & $3 \cdot$ LiOTf & $\mathrm{L}^{-}$ & $500: 1: 10$ & 100 & 360 & 57 & 4100 & 5600 & 1.06 & 4800 & \\
\hline 6 & $3 \cdot$ LiOTf & $\mathrm{L}^{-}$ & $1000: 1: 10$ & 100 & 360 & 34 & 5000 & 5600 & 1.06 & 4000 & \\
\hline 7 & 5 & $\mathrm{~L}^{-}$ & $1000: 1: 10$ & 60 & 180 & 88 & 12700 & 12900 & 1.07 & 11700 & \\
\hline 8 & 6 & $\mathrm{~L}^{-}$ & $1000: 1: 10$ & 60 & 180 & 88 & 12700 & 13300 & 1.06 & 9100 & \\
\hline $9^{g}$ & 7 & $\mathrm{~L}^{-}$ & $1000: 1: 10$ & 60 & 180 & 87 & 12500 & 11900 & 1.11 & 13600 & \\
\hline 10 & 8 & $\mathrm{~L}^{-}$ & $1000: 1: 10$ & 60 & 180 & 95 & 13800 & 14800 & 1.06 & 9700 & \\
\hline 11 & $7 \cdot$ LiOTf & $\mathrm{L}^{-}$ & $1000: 1: 10$ & 60 & 180 & 22 & 3200 & 4500 & 1.08 & 2000 & \\
\hline 12 & 9 & $\mathrm{~L}^{-}$ & $1000: 1: 10$ & 60 & 3 & 92 & 13300 & 14000 & 1.09 & 12400 & \\
\hline 13 & 9 & $\mathrm{~L}^{-}$ & $1000: 1: 10$ & 60 & 12 & 93 & 13400 & 13200 & 1.21 & 12500 & \\
\hline 14 & 9 & $\mathrm{~L}^{-}$ & $1000: 1: 10$ & 60 & 60 & 92 & 13300 & 15000 & 1.30 & 13800 & \\
\hline $15^{h}$ & 9 & $\mathrm{~L}^{-}$ & $5000: 1: 25$ & 60 & 45 & 96 & 27700 & 26200 & 1.10 & 26000 & \\
\hline 17 & 10 & $\mathrm{~L}^{-}$ & $500: 1: 10$ & 100 & 180 & 87 & 6300 & 9900 & 1.43 & 5600 & \\
\hline 18 & 2 & rac- & $500: 1: 10$ & 100 & 360 & 66 & 4800 & 7000 & 1.15 & 4500 & 0.68 \\
\hline $19^{g}$ & 7 & rac- & $1000: 1: 10$ & 60 & 180 & 92 & 13300 & 10300 & 1.13 & 8200 & 0.61 \\
\hline 20 & 9 & rac- & $1000: 1: 10$ & 60 & 12 & 92 & 13300 & 9200 & 1.23 & 13800 & 0.48 \\
\hline
\end{tabular}

${ }^{a}$ Polymerisations in toluene, $[\text { lactide }]_{\mathrm{o}}=2.0 \mathrm{M}$ unless otherwise stated. ${ }^{b}$ Isolated yield of PLA after precipitation. ${ }^{c} M_{\mathrm{n}, \text { theo }}=[\text { lactide }]_{\mathrm{o}} /[\mathrm{iPrOH}]_{\mathrm{o}} \times$ yield $\times 144.13+\mathrm{M}_{\mathrm{iPrOH}}{ }^{d}$ Determined by SEC $v s$. polystyrene standards, and corrected by a factor of 0.58 . ${ }^{40} e$ Determined by end-group analysis. ${ }^{f}$ Determined by homodecoupled ${ }^{1} \mathrm{H}$ NMR spectroscopy. ${ }^{g}$ From ref. $6 g .{ }^{h}[\mathrm{~L}-\text { lactide }]_{0}=4.0 \mathrm{M}$.

precatalysts. ${ }^{6 g}$ The polymerisation of rac-lactide proceeds with rates and control comparable to those of L-lactide, but the resulting polymers are essentially atactic (entries 18-20). Endgroup analysis (NMR and MALDI-ToF MS) confirmed the identity of the expected termini $\left(-\mathrm{CH}\left(\mathrm{CH}_{3}\right) \mathrm{OH}\right.$ and $\left(\mathrm{CH}_{3}\right)_{2} \mathrm{CHOC}-$ (=O)-).

Although they afford excellent control over the reactions parameters, the germylenes 1-3 are crippled by excessively low reaction rates, which in practice rules out their use as good ROP precatalysts, at least for the polymerisation of lactide. The presence of LiOTf had a beneficial effect on the catalytic activity of the germylene 3 , as $\mathbf{3}$-LiOTf proved substantially more active under otherwise identical experimental conditions (entries 3 vs. 5 and 4 vs. 6).

Although the nature of the ROP mechanism mediated by 3.LiOTf/iPrOH has not been elucidated, a possible intuitive explanation can be proposed: one may envisage that the strong Lewis acid $\mathrm{Li}^{+}$(although tamed by coordination of the crown ether) acts as an activator for the incoming monomer in a way reminiscent of the so-called "activated monomer" $2 c$ or "dualcatalyst" ${ }^{42}$ ROP mechanisms. The fact that, by contrast, 7.LiOTf afforded lower conversion than 7 (entries 9 and 11) probably arises from the much greater sensitivity of the former compared to $3 \cdot$ LiOTf, which may result in rapid catalyst decomposition under catalytic conditions. The catalytic performances of 5-7 (that of 8 is strictly analogous) have already been discussed elsewhere and will not be further detailed here. $^{6 g}$

The lead-based binary system $9 / \mathrm{PrOH}$ proved most effective. Under controlled conditions, it afforded very rapidly narrowly dispersed polymers of predictable lengths (entries 12, 15 and 20). Large quantities of monomer (5000 equiv. $v s . \mathrm{Pb}^{\mathrm{II}}$ ) were fully converted into medium molecular weight material within $45 \mathrm{~min}$ under mild conditions, and the resulting material exhibits excellent control over the molecular masses. In terms of combined productivity and activity, this stands on an equal footing with performances achieved with highly effective zinc-based systems for the polymerisation of lactide. ${ }^{13 b, e}$ The rapid increase in polydispersity observed after full conversion, which results from deleterious transesterification reactions, further testifies to the high reactivity of the binary catalyst 9/iPrOH (entries 12-14). The utilisation of the other plumbylene, 10, was not investigated in detail, but based on the limited role of the ligand under the chosen experimental conditions (vide supra), similar results may be anticipated.

\section{Conclusion}

Complete families of stable monomeric germylenes, stannylenes and plumbylenes supported by multidentate amino-, amino(ether)- and amino(crown-ether)-phenolate ligands are now available. The combination of crystallographic and heteronuclear NMR studies shows that independently of the nature of the metal centre and that of the co-ligand, the metal centre systematically exists in a 3-coordinate environment. Therefore, from a strict coordination point of view, the simple aminophenolate $\left\{\mathrm{LO}^{2}\right\}^{-}$is as good a ligand as the more encumbered and electron-donating amino(ether)- and amino(crown-ether)phenolates $\left\{\mathrm{LO}^{1}\right\}^{-}$and $\left\{\mathrm{LO}^{3}\right\}^{-}$, respectively. The NMR signature of these complexes containing NMR-active metal centres is readily provided by ${ }^{119} \mathrm{Sn}\left\{{ }^{1} \mathrm{H}\right\}$ and ${ }^{207} \mathrm{~Pb}\left\{{ }^{1} \mathrm{H}\right\} \quad \mathrm{NMR}$ spectroscopies. 
The fact that the metal in these divalent group 14 metallenes is satisfied in a 3-coordinate coordination environment enables the preparation of heterobimetallic complexes by inclusion of lithium salts in the crown-ether side-arm of the ligand $\left\{\mathrm{LO}^{3}\right\}^{-}$, at least with germanium(II) and tin(II) for which the metal- $\mathrm{O}_{\text {phenolate }}$ bond is fairly covalent. Up to now, only LiOTf has been used for this purpose with success, but several other complexes could in principle be obtained upon expanding the size of the crown-ether, and future efforts could aim at chelating a variety of monocations of alkali, coinage or triel metals.

If the catalytic activity of the simple germylenes, and in particular that supported by the amino-crown ether-phenolate $\left\{\mathrm{LO}^{3}\right\}^{-}$, for the polymerisation of lactide was disappointing, preliminary results suggest that it may be possible to boost their performance by inclusion of judicious cations in the macrocyclic tether. On the other hand, the plumbylenes have revealed excellent ability for the ROP of L-lactide, both in terms of control and reaction rates. Of course, the toxicity of lead is a major liability that under normal circumstances would immediately exclude it as a potential candidate for catalyst development in this field. However, maximising reaction rates and monomer loadings to the point where only ppm levels of metal catalyst are required should alleviate partly this issue, and in this aim we are now trying to develop other lead(II) precatalysts for immortal ROP catalysis.

\section{Experimental section}

\section{General procedures}

All manipulations were performed under an inert atmosphere by standard Schlenk techniques or in a dry, solvent-free glovebox (Jacomex; $\mathrm{O}_{2}<1 \mathrm{ppm}, \mathrm{H}_{2} \mathrm{O}<5 \mathrm{ppm}$ ) for catalyst loading. $\mathrm{SnCl}_{2}$ (Acros, 98\%), $\mathrm{PbCl}_{2}$ (Strem), $\mathrm{GeCl}_{2}$-dioxane (Acros) and LiOTf (Strem) were used as received. $\mathrm{HN}\left(\mathrm{SiMe}_{3}\right)_{2}$ (Acros) was dried over activated molecular sieves and distilled prior to use. Benzyl alcohol was dried and distilled over magnesium turnings and stored over $3 \AA$ molecular sieves. Potassium tert-butoxide was freshly $\left(190^{\circ} \mathrm{C}\right.$ under dynamic vacuum $<10^{-2}$ Torr $)$ sublimed prior to use. $\mathrm{Ge}\left(\mathrm{N}\left(\mathrm{SiMe}_{3}\right)_{2}\right)_{2},{ }^{43} \mathrm{Sn}\left(\mathrm{N}\left(\mathrm{SiMe}_{3}\right)_{2}\right)_{2},{ }^{44}$ (Pb$\left.\left(\mathrm{N}\left(\mathrm{SiMe}_{3}\right)_{2}\right)_{2}\right),{ }^{43}\left\{\mathrm{LO}^{1}\right\} \mathrm{Sn}\left(\mathrm{N}\left(\mathrm{SiMe}_{3}\right)_{2}\right)(6),{ }^{14 a}\left\{\mathrm{LO}^{2}\right\} \mathrm{Sn}\left(\mathrm{N}\left(\mathrm{SiMe}_{3}\right)_{2}\right)$ (7), ${ }^{14 a}\left\{\mathrm{LO}^{3}\right\} \mathrm{Sn}\left(\mathrm{N}\left(\mathrm{SiMe}_{3}\right)_{2}\right)(8),{ }^{6 g}\left\{\mathrm{LO}^{3}\right\} \mathrm{K},{ }^{13 h}$ and the pro-ligands $\left\{\mathrm{LO}^{1}\right\} \mathrm{H}-\left\{\mathrm{LO}^{4}\right\} \mathrm{H}^{35,45}$ were prepared by following literature protocols. Solvents (THF, $\mathrm{Et}_{2} \mathrm{O}, \mathrm{CH}_{2} \mathrm{Cl}_{2}$, pentane and toluene) were purified and dried (water contents below $8 \mathrm{ppm}$ ) over alumina columns (MBraun SPS). THF was further distilled under argon from sodium mirror/benzophenone ketyl. All deuterated solvents (Eurisotop, Saclay, France) were stored in sealed ampoules over activated $3 \AA$ molecular sieves and were thoroughly degassed by several freeze-thaw-vacuum cycles. Technical grade L-LA was provided by Total Petrochemicals and purified by recrystallization from a hot $\left(80^{\circ} \mathrm{C}\right)$, concentrated iPrOH solution, followed by two subsequent recrystallizations in hot $\left(105^{\circ} \mathrm{C}\right)$ toluene. After purification, L-lactide was stored at all times at a temperature of $-30^{\circ} \mathrm{C}$ in the inert atmosphere of the glove-box. Racemic lactide (Acros) was purified in the same way.

NMR spectra were recorded using Bruker AC-300, AM-400 and AM-500 spectrometers. All ${ }^{1} \mathrm{H}$ and ${ }^{13} \mathrm{C}\left\{{ }^{1} \mathrm{H}\right\}$ chemical shifts were determined using residual signals of the deuterated solvents and were calibrated vs. $\mathrm{SiMe}_{4}$. Assignment of the signals was carried out using $1 \mathrm{D}\left({ }^{1} \mathrm{H},{ }^{13} \mathrm{C}\left\{{ }^{1} \mathrm{H}\right\}\right)$ and $2 \mathrm{D}$ (COSY, HMBC, HMQC) NMR experiments. ${ }^{19} \mathrm{~F}\left\{{ }^{1} \mathrm{H}\right\}$ chemical shifts were determined by external reference to an aqueous solution of $\mathrm{NaBF}_{4}$. A capillary containing an aqueous solution of $\mathrm{LiCl}\left(\delta 7_{\mathrm{Li}}=\right.$ $0 \mathrm{ppm}$ ) was used for the calibration of ${ }^{7} \mathrm{Li}$ NMR spectra. ${ }^{207} \mathrm{~Pb}$ NMR spectra were referenced against a solution of $\mathrm{Pb}$ $\left[\mathrm{N}\left(\mathrm{SiMe}_{3}\right)_{2}\right]_{2}$ in benzene- $d_{6}\left(\delta_{207 \mathrm{~Pb}}=+4916 \mathrm{ppm}\right) .{ }^{119} \mathrm{Sn} \mathrm{NMR}$ spectra were externally calibrated $v s$. $\mathrm{SnMe}_{4}$.

Elemental analyses were performed using a Carlo Erba 1108 Elemental Analyzer instrument at the London Metropolitan University by Stephen Boyer and were the average of a minimum of two independent measurements.

Size Exclusion Chromatography (SEC) measurements were performed using an Agilent PL-GPC50 equipped with two PLgel $5 \AA$ A MIXED-C columns and a refractive index detector. The column was eluted with THF at room temperature at $1.0 \mathrm{~mL} \mathrm{~min} \mathrm{~m}^{-1}$ and was calibrated using 11 monodisperse polystyrene standards in the range of $580-380000 \mathrm{~g} \mathrm{~mol}^{-1}$. The molecular weights of all PLAs were corrected by a factor of $0.58 .^{40}$

$\left\{\mathbf{L O}^{1}\right\} \mathrm{Ge}\left(\mathbf{N}\left(\mathrm{SiMe}_{3}\right)_{2}\right)$ (1). A solution of $\left\{\mathrm{LO}^{1}\right\} \mathrm{H} \quad(0.35 \mathrm{~g}$, $1.00 \mathrm{mmol})$ in diethyl ether $(20 \mathrm{~mL})$ was added at $-30^{\circ} \mathrm{C}$ over a period of $30 \mathrm{~min}$ to a solution of $\mathrm{Ge}\left(\mathrm{N}\left(\mathrm{SiMe}_{3}\right)_{2}\right)_{2}(0.40 \mathrm{~g}$, $1.02 \mathrm{mmol})$ in diethyl ether $(20 \mathrm{~mL})$. The colour of the solution gradually discharged from deep orange to light yellow. The resulting mixture was warmed to room temperature and stirred overnight, and the volatiles were removed under vacuum. The resulting powder was washed with cold pentane $(2 \mathrm{~mL})$ at $-20{ }^{\circ} \mathrm{C}$ and dried in vacuo to give pure $\mathbf{1}$ as a colourless powder $(0.51 \mathrm{~g}, 87 \%)$. Single crystals of 1 suitable for X-ray diffraction crystallography were obtained by recrystallisation from a cold mixture of pentane and toluene. ${ }^{1} \mathrm{H}$ NMR (toluene$\left.d_{8}, 500.13 \mathrm{MHz}, 0{ }^{\circ} \mathrm{C}\right): \delta=7.60\left(\mathrm{~d},{ }^{4} J_{\mathrm{HH}}=2.5 \mathrm{~Hz}, 1 \mathrm{H}\right.$, aromatic$H), 7.00\left(\mathrm{~d},{ }^{4} \mathrm{~J}_{\mathrm{HH}}=2.5 \mathrm{~Hz}, 1 \mathrm{H}\right.$, aromatic- $\left.H\right), 4.11\left(\mathrm{AB} \operatorname{spin},{ }^{2} \mathrm{~J}_{\mathrm{HH}}=\right.$ $13.6 \mathrm{~Hz}, 1 \mathrm{H}, \operatorname{ArCH}(H) \mathrm{N}), 3.72-3.62\left(\mathrm{~m}, 2 \mathrm{H}, \mathrm{CH}_{2} \mathrm{OCH}_{3}\right)$, 3.53-3.46 $\left(\mathrm{m}, 2 \mathrm{H}, \mathrm{CH}(H) \mathrm{OCH}_{3}\right.$ and $\left.\operatorname{ArCH}(\mathrm{H}) \mathrm{N}\right), 3.43-3.38(\mathrm{~m}$, $\left.1 \mathrm{H}, \mathrm{CH}(H) \mathrm{OCH}_{3}\right), 3.23-3.20\left(\mathrm{~m}, 1 \mathrm{H}, \mathrm{NCH}_{2} \mathrm{CH}_{2}\right), 3.09(\mathrm{~s}, 3 \mathrm{H}$, $\left.\mathrm{OCH}_{3}\right), 2.97-2.91\left(\mathrm{~m}, 4 \mathrm{H}, \mathrm{NCH}_{2} \mathrm{CH}_{2}\right.$ and $\left.\mathrm{OCH}_{3}\right), 2.89-2.82(\mathrm{~m}$, $\left.1 \mathrm{H}, \mathrm{NCH}_{2} \mathrm{CH}_{2}\right), 2.81-2.74\left(\mathrm{~m}, 1 \mathrm{H}, \mathrm{NCH}_{2} \mathrm{CH}_{2}\right), 1.70(\mathrm{~s}, 9 \mathrm{H}$, $\left.\mathrm{C}\left(\mathrm{CH}_{3}\right)_{3}\right), 1.39\left(\mathrm{~s}, 9 \mathrm{H}, \mathrm{C}\left(\mathrm{CH}_{3}\right)_{3}\right), 0.59\left(\mathrm{~s}, 9 \mathrm{H},\left(\mathrm{Si}\left(\mathrm{CH}_{3}\right)_{3}\right)_{2}\right), 0.46(\mathrm{~s}$, $\left.9 \mathrm{H},\left(\mathrm{Si}\left(\mathrm{CH}_{3}\right)_{3}\right)_{2}\right)$ ppm. ${ }^{13} \mathrm{C}\left\{{ }^{1} \mathrm{H}\right\}$ NMR (toluene- $d_{8}, 125.62 \mathrm{MHz}$, $0{ }^{\circ} \mathrm{C}$ ): $\delta=156.15,140.65,140.61,126.05,125.56$ and 124.30 (all aromatic- $C$ ), 68.99 and 66.93 (both $\mathrm{OCH}_{2}$ ), 58.18 and 58.07 (both $\left.\mathrm{OCH}_{3}\right), 57.74\left(\mathrm{ArCH}_{2} \mathrm{~N}\right), 52.71$ and 51.48 (both $\left.\mathrm{NCH}_{2} \mathrm{CH}_{2}\right), 34.83\left(C\left(\mathrm{CH}_{3}\right)_{3}\right), 34.06\left(C\left(\mathrm{CH}_{3}\right)_{3}\right), 31.64\left(\mathrm{C}\left(\mathrm{CH}_{3}\right)_{3}\right)$, $30.33\left(\mathrm{C}\left(\mathrm{CH}_{3}\right)_{3}\right), 6.61$ and 5.41 (both $\left.\mathrm{N}\left(\mathrm{Si}\left(\mathrm{CH}_{3}\right)_{3}\right)_{2}\right)$ ppm. ${ }^{29} \mathrm{Si}\left\{{ }^{1} \mathrm{H}\right\}$ NMR (toluene- $d_{8}, 79.49 \mathrm{MHz}, 25{ }^{\circ} \mathrm{C}$ ): $\delta=0.41 \mathrm{ppm}$. Elemental analysis for $\mathrm{C}_{27} \mathrm{H}_{54} \mathrm{GeN}_{2} \mathrm{O}_{3} \mathrm{Si}_{2}$ (583.54 $\left.\mathrm{g} \mathrm{mol}^{-1}\right)$ : theoretical, $\mathrm{C} 55.6 \%, \mathrm{H} 9.3 \%, \mathrm{~N} 4.8 \%$; found $\mathrm{C} 55.7 \%$, H $10.0 \%$, N $4.7 \%$. 
$\left\{\mathbf{L O}^{2}\right\} \mathbf{G e}\left(\mathbf{N}\left(\mathrm{SiMe}_{3}\right)_{2}\right)$ (2). Following a protocol similar to that described for 1 , the reaction of $\left\{\mathrm{LO}^{2}\right\} \mathrm{H}(0.29 \mathrm{~g}, 1.00 \mathrm{mmol})$ and $\mathrm{Ge}\left(\mathrm{N}\left(\mathrm{SiMe}_{3}\right)_{2}\right)_{2}(0.40 \mathrm{~g}, 1.02 \mathrm{mmol})$ afforded 2 as a white powder $(0.31 \mathrm{~g}, 47 \%)$. Single crystals of 2 suitable for X-ray diffraction studies were grown from a cold mixture of pentane and toluene. ${ }^{1} \mathrm{H}$ NMR (toluene- $d_{8}, 500.13 \mathrm{MHz}, 25^{\circ} \mathrm{C}$ ): $\delta=7.54$ $\left(\mathrm{d},{ }^{4} \mathrm{~J}_{\mathrm{HH}}=2.5 \mathrm{~Hz}, 1 \mathrm{H}\right.$, aromatic- $\left.H\right), 6.85\left(\mathrm{~d},{ }^{4} J_{\mathrm{HH}}=2.5 \mathrm{~Hz}, 1 \mathrm{H}\right.$, aromatic- $H$ ), $3.77\left(\mathrm{AB}\right.$ spin, $\left.{ }^{2} \mathrm{~J}_{\mathrm{HH}}=13.6 \mathrm{~Hz}, 1 \mathrm{H}, \operatorname{ArCH}(H) \mathrm{N}\right)$, $2.92\left(\mathrm{AB}\right.$ spin, $\left.{ }^{2} J_{\mathrm{HH}}=13.6 \mathrm{~Hz}, 1 \mathrm{H}, \operatorname{ArCH}(\mathrm{H}) \mathrm{N}\right), 2.83-2.04(\mathrm{br} \mathrm{m}$, $\left.4 \mathrm{H}, \mathrm{NCH}_{2} \mathrm{CH}_{3}\right), 1.63\left(\mathrm{~s}, 9 \mathrm{H}, \mathrm{C}\left(\mathrm{CH}_{3}\right)_{3}\right), 1.36\left(\mathrm{~s}, 9 \mathrm{H}, \mathrm{C}\left(\mathrm{CH}_{3}\right)_{3}\right)$, 0.73-0.68 (br m, 6H, ${ }^{3} J_{\mathrm{HH}}=7.5 \mathrm{~Hz}$, both $\mathrm{NCH}_{2} \mathrm{CH}_{3}$ ), 0.48-0.38 (br m, $\left.18 \mathrm{H}, \mathrm{N}\left(\mathrm{Si}\left(\mathrm{CH}_{3}\right)_{3}\right)_{2}\right)$ ppm. ${ }^{13} \mathrm{C}\left\{{ }^{1} \mathrm{H}\right\}$ NMR (toluene- $d_{8}$, 125.62 MHz, $\left.25^{\circ} \mathrm{C}\right): \delta=156.70,141.26,141.07,125.98,125.43$ and 124.82 (all aromatic-C), $56.40\left(\mathrm{ArCH}_{2} \mathrm{~N}\right), 45.79$ and 45.33 (both $\left.\mathrm{NCH}_{2} \mathrm{CH}_{3}\right), 35.38\left(C\left(\mathrm{CH}_{3}\right)_{3}\right), 34.59\left(\mathrm{C}\left(\mathrm{CH}_{3}\right)_{3}\right), 32.20$ $\left(\mathrm{C}\left(\mathrm{CH}_{3}\right)_{3}\right), 30.93\left(\mathrm{C}\left(\mathrm{CH}_{3}\right)_{3}\right), 9.27$ and 7.04 (both $\mathrm{NCH}_{2} \mathrm{CH}_{3}$ ), 7.18 and 6.07 (both $\left.\mathrm{N}\left(\mathrm{Si}\left(\mathrm{CH}_{3}\right)_{3}\right)_{2}\right)$ ppm. ${ }^{29} \mathrm{Si}\left\{{ }^{1} \mathrm{H}\right\}$ NMR (toluene$\left.d_{8}, 79.49 \mathrm{MHz}, 25{ }^{\circ} \mathrm{C}\right): \delta=0.06 \mathrm{ppm}$. Elemental analysis for $\mathrm{C}_{25} \mathrm{H}_{50} \mathrm{GeN}_{2} \mathrm{OSi}_{2}\left(523.49 \mathrm{~g} \mathrm{~mol}^{-1}\right)$ : theoretical, C $57.4 \%, \mathrm{H}$ 9.6\%, N 5.3\%; found C 57.2\%, H 9.7\%, N 5.4\%.

$\left\{\mathbf{L O}^{3}\right\} \mathbf{G e}\left(\mathbf{N}\left(\mathrm{SiMe}_{3}\right)_{2}\right)$ (3). Method 1: $\mathrm{K}\left(\mathrm{N}\left(\mathrm{SiMe}_{3}\right)_{2}\right) \quad(0.40 \mathrm{~g}$, $2.00 \mathrm{mmol}$ ) was added in portions with a bent finger to a solution of $\left\{\mathrm{LO}^{3}\right\} \mathrm{H}(0.44 \mathrm{~g}, 1.00 \mathrm{mmol})$ in THF $(15 \mathrm{~mL})$. After stirring for $2 \mathrm{~h}$ at room temperature, the resulting solution was added dropwise to a solution of $\mathrm{GeCl}_{2}$-dioxane in THF. The reaction mixture was stirred overnight. After removing the volatiles under reduced pressure, the crude product was extracted with pentane $(3 \times 10 \mathrm{~mL})$. The solution was then taken to dryness and the resulting foam was stripped with pentane $(4 \times 3 \mathrm{~mL})$. The resulting pale yellow solid was washed with pentane $(4 \mathrm{~mL})$ and dried in vacuo to constant weight to give 3 as a white powder $(0.31 \mathrm{~g}, 46 \%)$.

Method 2: A solution of $\left\{\mathrm{LO}^{3}\right\} \mathrm{H}(0.44 \mathrm{~g}, 1.00 \mathrm{mmol})$ in diethyl ether $(20 \mathrm{~mL})$ was added at $-30{ }^{\circ} \mathrm{C}$ over a period of $30 \mathrm{~min}$ to a solution of $\mathrm{Ge}\left(\mathrm{N}\left(\mathrm{SiMe}_{3}\right)_{2}\right)_{2}(0.40 \mathrm{~g}, 1.02 \mathrm{mmol})$ in diethyl ether $(20 \mathrm{~mL})$. A rapid change of coloration from deep orange to light yellow was observed. The resulting mixture was warmed to room temperature and stirred overnight, and the volatiles were removed under vacuum. The resulting powder was washed with cold pentane $(3 \mathrm{~mL})$ at $-20{ }^{\circ} \mathrm{C}$ and dried in vacuo to give analytically pure 3 as a white powder $(0.54 \mathrm{~g}$, $81 \%)$.

Single crystals of 3 suitable for X-ray diffraction crystallography were obtained by recrystallisation from pentane. ${ }^{1} \mathrm{H}$ NMR (toluene- $\left.d_{8}, 400.13 \mathrm{MHz}, 25^{\circ} \mathrm{C}\right): \delta=7.61\left(\mathrm{~d},{ }^{4} J_{\mathrm{HH}}=2.5 \mathrm{~Hz}, 1 \mathrm{H}\right.$, aromatic- $H), 6.99\left(\mathrm{~d},{ }^{4} J_{\mathrm{HH}}=2.5 \mathrm{~Hz}, 1 \mathrm{H}\right.$, aromatic- $\left.H\right), 4.02(\mathrm{AB}$ spin, $\left.{ }^{2} J_{\mathrm{HH}}=13.6 \mathrm{~Hz}, 1 \mathrm{H}, \operatorname{ArCH}(H) \mathrm{N}\right), 3.84-3.79(\mathrm{br} \mathrm{m}, 3 \mathrm{H}$, $\mathrm{OCH}_{2} \mathrm{CH}_{2} \mathrm{O}$ ), $3.47\left(\mathrm{AB}\right.$ spin, $\left.{ }^{2} J_{\mathrm{HH}}=13.6 \mathrm{~Hz}, 1 \mathrm{H}, \operatorname{ArCH}(\mathrm{H}) \mathrm{N}\right)$, $3.46-3.23,3.17-3.13$ and $2.85-2.72$ (br m, $17 \mathrm{H}, \mathrm{OCH}_{2} \mathrm{CH}_{2} \mathrm{O}$ and $\left.\mathrm{NCH}_{2} \mathrm{CH}_{2}\right), 1.65$ (s, 9H, $\left.\mathrm{C}\left(\mathrm{CH}_{3}\right)_{3}\right), 1.36\left(\mathrm{~s}, 9 \mathrm{H}, \mathrm{C}\left(\mathrm{CH}_{3}\right)_{3}\right)$, 0.52 (br, 9H, N( $\left.\left.\mathrm{Si}\left(\mathrm{CH}_{3}\right)_{3}\right)_{2}\right), 0.43$ (br, 9H, N( $\left.\left.\mathrm{Si}\left(\mathrm{CH}_{3}\right)_{3}\right)_{2}\right) \mathrm{ppm}$. ${ }^{13} \mathrm{C}\left\{{ }^{1} \mathrm{H}\right\}$ NMR (benzene- $d_{6}, 100.62 \mathrm{MHz}, 25{ }^{\circ} \mathrm{C}$ ): $\delta=156.71$, 141.11, 141.08, 126.53, 125.89 and 124.63 (all aromatic-C), $71.77,71.30,70.73,70.57,70.50,67.39$ and $65.96\left(\right.$ all $\left.\mathrm{OCH}_{2}\right)$, $56.77\left(\mathrm{ArCH}_{2} \mathrm{~N}\right), 53.69$ and $52.84\left(\mathrm{NCH}_{2} \mathrm{CH}_{2} \mathrm{O}\right), 35.21$ and 34.42 (both $\left.\mathrm{C}\left(\mathrm{CH}_{3}\right)_{3}\right), 32.03$ and 30.79 (both $\left.\mathrm{C}\left(\mathrm{CH}_{3}\right)_{3}\right), 6.93$ and 5.90 (both $\left(\mathrm{Si}\left(\mathrm{CH}_{3}\right)_{3}\right)_{2}$ ) ppm. ${ }^{29} \mathrm{Si}\left\{{ }^{1} \mathrm{H}\right\}$ NMR (benzene- $d_{6}, 79.49 \mathrm{MHz}$, $25{ }^{\circ} \mathrm{C}$ ): $\delta=2.37 \mathrm{ppm}$. Elemental analysis for $\mathrm{C}_{31} \mathrm{H}_{60} \mathrm{GeN}_{2} \mathrm{O}_{5} \mathrm{Si}_{2}$ (669.63 $\mathrm{g} \mathrm{mol}^{-1}$ ): theoretical, C 55.6\%, H 9.0\%, N 4.2\%; found C $55.5 \%, \mathrm{H} 8.9 \%$, N $4.1 \%$.

$\left\{\mathbf{L O}^{3}\right\}$ GeCl. A solution of $\left\{\mathrm{LO}^{3}\right\} \mathrm{K}(0.50 \mathrm{~g}, 1.05 \mathrm{mmol})$ in THF $(20 \mathrm{~mL})$ was added dropwise to a solution of $\mathrm{GeCl}_{2}$.dioxane $(0.25 \mathrm{~g}, 1.06 \mathrm{mmol})$ in THF $(30 \mathrm{~mL})$. The reaction mixture was stirred overnight at room temperature. After removal of the volatiles at low pressure, the crude product was extracted with $\mathrm{Et}_{2} \mathrm{O}(3 \times 7 \mathrm{~mL})$ and dried in vacuo to give the title compound $(0.41 \mathrm{~g}, 72 \%)$ as a colourless solid. Single crystals of $\left\{\mathrm{LO}^{3}\right\} \mathrm{GeCl}$ were grown from a concentrated toluene solution at room temperature and their structure was solved. ${ }^{1} \mathrm{H}$ NMR (benzene$d_{6}, 298 \mathrm{~K}, 500.13 \mathrm{MHz}$ ): $\delta=7.58\left(\mathrm{~d},{ }^{4} J_{\mathrm{HH}}=2.5 \mathrm{~Hz}, 1 \mathrm{H}\right.$, aromatic- $H), 6.78\left(\mathrm{~d},{ }^{4} J_{\mathrm{HH}}=2.5 \mathrm{~Hz}, 1 \mathrm{H}\right.$, aromatic- $\left.H\right), 4.30-2.39(\mathrm{~m}$, $24 \mathrm{H}$, all $\mathrm{NCH}_{2}$ and $\left.\mathrm{OCH}_{2}\right), 1.70\left(\mathrm{~s}, 9 \mathrm{H}, \mathrm{C}\left(\mathrm{CH}_{3}\right)_{3}\right), 1.37(\mathrm{~s}, 9 \mathrm{H}$, $\left.\mathrm{C}\left(\mathrm{CH}_{3}\right)_{3}\right) \mathrm{ppm} ;{ }^{13} \mathrm{C}\left\{{ }^{1} \mathrm{H}\right\}$ NMR (benzene- $d_{6}, 298 \mathrm{~K}, 125.76 \mathrm{MHz}$ ): $\delta=155.02,140.73,139.42,125.42,124.85$ and 120.75 (all aromatic- $C$ ), 71.43, 71.25, 70.44, 70.31, 66.42, 65.60 and 57.11 (all $\mathrm{NCH}_{2}$ and $\left.\mathrm{OCH}_{2}\right), 54.89\left(\mathrm{ArCH}_{2} \mathrm{~N}\right), \quad 53.03$ and 51.32 $\left(\mathrm{NCH}_{2} \mathrm{CH}_{2} \mathrm{O}\right), 35.42$ and 34.37 (both $\left.C\left(\mathrm{CH}_{3}\right)_{3}\right), 32.00$ and 30.46 (both $\left.\mathrm{C}\left(\mathrm{CH}_{3}\right)_{3}\right)$ ppm. Elemental analysis for $\mathrm{C}_{25} \mathrm{H}_{42} \mathrm{ClGeNO}_{5}$ (544.70 $\mathrm{g} \mathrm{mol}^{-1}$ ): theoretical, C 55.1\%, H 7.8\%, N 2.6\%; found C $54.9 \%, \mathrm{H} 7.6 \%$, N $2.5 \%$.

$\left\{\mathbf{L O}^{4}\right\} \mathbf{S n}\left(\mathbf{N}\left(\mathrm{SiMe}_{3}\right)_{2}\right)$ (8). A solution of $\left\{\mathrm{LO}^{4}\right\} \mathrm{H} \quad(0.20 \mathrm{~g}$, $0.50 \mathrm{mmol})$ in diethyl ether $(20 \mathrm{~mL})$ was added at $-80^{\circ} \mathrm{C}$ over a period of $30 \mathrm{~min}$ to a solution of $\mathrm{Sn}\left(\mathrm{N}\left(\mathrm{SiMe}_{3}\right)_{2}\right)_{2}(0.22 \mathrm{~g}$, $0.51 \mathrm{mmol})$ in diethyl ether $(20 \mathrm{~mL})$. The colour of the solution rapidly changed from deep orange to yellow. The resulting mixture was warmed to room temperature and the volatiles were removed under vacuum. The resulting powder was washed with cold pentane $(2 \mathrm{~mL})$ at $-20{ }^{\circ} \mathrm{C}$ and dried in vacuo to give 8 as a white powder $(0.19 \mathrm{~g}, 57 \%)$. Single crystals of 8 suitable for X-ray diffraction were obtained by recrystallisation from a cold mixture of pentane and toluene. ${ }^{1} \mathrm{H}$ NMR (toluene$\left.d_{8}, 500.13 \mathrm{MHz}, 25{ }^{\circ} \mathrm{C}\right): \delta=7.55\left(\mathrm{~d},{ }^{4} \mathrm{~J}_{\mathrm{HH}}=2.5 \mathrm{~Hz}, 1 \mathrm{H}\right.$, aromatic- $H), 6.91\left(\mathrm{~d},{ }^{4} \mathrm{~J}_{\mathrm{HH}}=2.5 \mathrm{~Hz}, 1 \mathrm{H}\right.$, aromatic- $\left.H\right), 4.06(\mathrm{br}, 1 \mathrm{H}$, $\operatorname{ArCH}(H) \mathrm{N}), 3.86-3.17$ (br m, $15 \mathrm{H}, \operatorname{ArCH}(\mathrm{H}) \mathrm{N}$, all $\mathrm{OCH}_{2}$ and $\left.\mathrm{NCH}_{2} \mathrm{CH}_{2}\right), 2.79-2.76$ (br, $\left.2 \mathrm{H}, \mathrm{NCH}_{2} \mathrm{CH}_{2}\right), 1.65\left(\mathrm{~s}, 9 \mathrm{H}, \mathrm{C}\left(\mathrm{CH}_{3}\right)_{3}\right)$, 1.36 (s, 9H, C( $\left.\left.\mathrm{CH}_{3}\right)_{3}\right), 0.46$ ppm (br s, $\left.18 \mathrm{H}, \mathrm{N}\left(\mathrm{Si}\left(\mathrm{CH}_{3}\right)_{3}\right)_{2}\right) .{ }^{13} \mathrm{C}-$ $\left\{{ }^{1} \mathrm{H}\right\}$ NMR (benzene- $\left.d_{6}, 125.76 \mathrm{MHz}, 25{ }^{\circ} \mathrm{C}\right): \delta=158.96,140.91$, $139.69,128.46,126.95$ and 124.67 (all aromatic- $C$ ), 71.89, 70.81 and 70.56 (four partly overlapping $\mathrm{OCH}_{2} \mathrm{CH}_{2} \mathrm{O}$ ), 67.65 and 65.42 (both $\mathrm{NCH}_{2} \mathrm{CH}_{2} \mathrm{O}$ ), $57.59\left(\mathrm{ArCH}_{2} \mathrm{~N}\right), 52.98$ and 52.00 (both $\mathrm{NCH}_{2} \mathrm{CH}_{2} \mathrm{O}$ ), 35.45 and 34.54 (both $\left.\mathrm{C}\left(\mathrm{CH}_{3}\right)_{3}\right), 32.28$ and 30.83 (both $\left.\mathrm{C}\left(\mathrm{CH}_{3}\right)_{3}\right), 7.06 \mathrm{ppm}\left(\mathrm{N}\left(\mathrm{Si}\left(\mathrm{CH}_{3}\right)_{3}\right)_{2}\right) .{ }^{29} \mathrm{Si}\left\{{ }^{1} \mathrm{H}\right\} \mathrm{NMR}$ (toluene- $d_{8}, 79.49 \mathrm{MHz}, 25{ }^{\circ} \mathrm{C}$ ): $\delta=-0.34 \mathrm{ppm} .{ }^{119} \mathrm{Sn}\left\{{ }^{1} \mathrm{H}\right\} \mathrm{NMR}$ (toluene- $d_{8}, 149.20 \mathrm{MHz}, 90{ }^{\circ} \mathrm{C}$ ): $\delta-49.9 \mathrm{ppm}$. Elemental analysis for $\mathrm{C}_{29} \mathrm{H}_{56} \mathrm{~N}_{2} \mathrm{O}_{4} \mathrm{Si}_{2} \mathrm{Sn}\left(671.65 \mathrm{~g} \mathrm{~mol}^{-1}\right)$ : theoretical, C 51.9, $\mathrm{H}$ 8.4, N 4.2; found C 51.7, H 8.5, N 4.1\%.

$\left\{\mathbf{L O}^{3}\right\}$ SnCl. A solution of $\left\{\mathrm{LO}^{3}\right\} \mathrm{K}(0.48 \mathrm{~g}, 1.00 \mathrm{mmol})$ in THF $(20 \mathrm{~mL})$ was added dropwise to a solution of $\mathrm{SnCl}_{2}(0.19 \mathrm{~g}$, $1.01 \mathrm{mmol})$ in THF $(30 \mathrm{~mL})$. The reaction mixture was stirred overnight at room temperature. After removal of the volatiles at low pressure, the crude product was extracted with $\mathrm{Et}_{2} \mathrm{O}$ $(3 \times 7 \mathrm{~mL})$ and dried in vacuo to give the title compound 
$(0.32 \mathrm{~g}, 54 \%)$ as a colourless solid. ${ }^{1} \mathrm{H}$ NMR (benzene- $d_{6}$, $298 \mathrm{~K}, 400.13 \mathrm{MHz}$ ) $: \delta=7.64\left(\mathrm{~d},{ }^{4} J_{\mathrm{HH}}=2.4 \mathrm{~Hz}, 1 \mathrm{H}\right.$, aromatic$H), 6.80\left(\mathrm{~d},{ }^{4} J_{\mathrm{HH}}=2.4 \mathrm{~Hz}, 1 \mathrm{H}\right.$, aromatic- $\left.H\right), 3.83(\mathrm{~m}, 2 \mathrm{H}$, $\left.\mathrm{ArCH}_{2} \mathrm{~N}\right), 3.61-3.56\left(\mathrm{~m}, 2 \mathrm{H}, \mathrm{NCH}_{2} \mathrm{CH}_{2}\right), 3.30-3.23(\mathrm{~m}, 6 \mathrm{H}$, $\left.\mathrm{OCH}_{2}\right)$, 3.11-3.07 (m, 8H, OCH $\left.\mathrm{O}_{2}\right)$ 2.97-2.95 (m, 2H, $\left.\mathrm{OCH}_{2}\right)$, 2.33-2.30 (m, 2H, $\left.\mathrm{NCH}_{2} \mathrm{CH}_{2}\right), 1.78\left(\mathrm{~s}, 9 \mathrm{H}, \mathrm{C}\left(\mathrm{CH}_{3}\right)_{3}\right), 1.43 \mathrm{ppm}$ (s, 9H, $\left.\mathrm{C}\left(\mathrm{CH}_{3}\right)_{3}\right) ;{ }^{13} \mathrm{C}\left\{{ }^{1} \mathrm{H}\right\} \quad \mathrm{NMR}$ (benzene- $d_{6}, 298 \mathrm{~K}$, 100.62 MHz): $\delta=160.00,139.30,138.39,126.63,125.12$ and 122.20 (all aromatic- $C$ ), 70.91, 70.51 and $67.13\left(\right.$ all $\mathrm{OCH}_{2}$ ), $61.00\left(\mathrm{NCH}_{2} \mathrm{CH}_{2}\right), 54.11\left(\mathrm{ArCH}_{2} \mathrm{~N}\right), 36.01$ and 34.72 (both $\left.C\left(\mathrm{CH}_{3}\right)_{3}\right), 32.68$ and 30.95 (both $\left.\mathrm{C}\left(\mathrm{CH}_{3}\right)_{3}\right) \mathrm{ppm} ;{ }^{119} \mathrm{Sn}\left\{{ }^{1} \mathrm{H}\right\} \mathrm{NMR}$ (toluene- $d_{8}, 149.20 \mathrm{MHz}, 25^{\circ} \mathrm{C}$ ): $\delta-385.0 \mathrm{ppm}$. Elemental analysis for $\mathrm{C}_{25} \mathrm{H}_{42} \mathrm{ClNO}_{5} \mathrm{Sn}\left(590.77 \mathrm{~g} \mathrm{~mol}^{-1}\right)$ : theoretical, C $50.8 \%$, $\mathrm{H} 7.2 \%$, N 2.4\%; found C 50.9\%, H 7.2\%, N 2.4\%.

$\left\{\mathbf{L O}^{1}\right\} \mathbf{P b}\left(\mathbf{N}\left(\mathrm{SiMe}_{3}\right)_{2}\right)$ (9). By following a protocol similar to that described for $\mathbf{1}$, the reaction of $\left\{\mathrm{LO}^{1}\right\} \mathrm{H}(0.42 \mathrm{~g}$, $1.20 \mathrm{mmol})$ and $\mathrm{Pb}\left(\mathrm{N}\left(\mathrm{SiMe}_{3}\right)_{2}\right)_{2}(0.64 \mathrm{~g}, 1.22 \mathrm{mmol})$ afforded 9 as a white powder $(0.72 \mathrm{~g}, 84 \%)$. Single crystals of 9 suitable for X-ray diffraction were obtained by recrystallisation from a cold mixture of pentane and diethyl ether. ${ }^{1} \mathrm{H}$ NMR (toluene$\left.d_{8}, 500.13 \mathrm{MHz}, 25{ }^{\circ} \mathrm{C}\right): \delta=7.62\left(\mathrm{~d}, 1 \mathrm{H},{ }^{4} J_{\mathrm{HH}}=2.5 \mathrm{~Hz}\right.$, aromatic- $H), 6.93\left(\mathrm{~d}, 1 \mathrm{H},{ }^{4} J_{\mathrm{HH}}=2.5 \mathrm{~Hz}\right.$, aromatic- $\left.H\right), 3.93-3.89(\mathrm{br}$ $\mathrm{m}, 4 \mathrm{H}, \mathrm{ArCH}_{2} \mathrm{~N}$ and $\left.\mathrm{NCH}_{2} \mathrm{CH}_{2}\right), 3.41-2.99\left(\mathrm{dt}, 4 \mathrm{H},{ }^{3} J_{\mathrm{HH}}=\right.$ $10.5 \mathrm{~Hz}, \mathrm{NCH}_{2} \mathrm{CH}_{2} \mathrm{O}$ ), 2.91 (br, $2 \mathrm{H}, \mathrm{NCH}_{2} \mathrm{CH}_{2}$ ), 2.85 (s, 6H, $\left.\mathrm{OCH}_{3}\right), 1.68\left(\mathrm{~s}, 9 \mathrm{H}, \mathrm{C}\left(\mathrm{CH}_{3}\right)_{3}\right), 1.39\left(\mathrm{~s}, 9 \mathrm{H}, \mathrm{C}\left(\mathrm{CH}_{3}\right)_{3}\right), 0.43$ (s, $\left.18 \mathrm{H}, \quad \mathrm{N}\left(\mathrm{Si}\left(\mathrm{CH}_{3}\right)_{3}\right)_{2}\right) \quad \mathrm{ppm} .{ }^{13} \mathrm{C}\left\{{ }^{1} \mathrm{H}\right\} \quad \mathrm{NMR}$ (toluene- $d_{8}$, 125.76 MHz, $\left.25^{\circ} \mathrm{C}\right): \delta=161.00,140.90,137.80,126.97,124.73$ and 124.68 (all aromatic- $C$ ), $68.30\left(\mathrm{OCH}_{2}\right), 58.48\left(\mathrm{OCH}_{3}\right), 57.74-$ $\left(\mathrm{ArCH}_{2} \mathrm{~N}\right), 51.78\left(\mathrm{NCH}_{2} \mathrm{CH}_{2}\right), 35.58\left(C\left(\mathrm{CH}_{3}\right)_{3}\right), 34.34\left(C\left(\mathrm{CH}_{3}\right)_{3}\right)$, $32.51\left(\mathrm{C}\left(\mathrm{CH}_{3}\right)_{3}\right), 30.98\left(\mathrm{C}\left(\mathrm{CH}_{3}\right)_{3}\right), 7.19\left(\mathrm{~N}\left(\mathrm{Si}\left(\mathrm{CH}_{3}\right)_{3}\right)_{2}\right)$ ppm. ${ }^{29} \mathrm{Si}-$ $\left\{{ }^{1} \mathrm{H}\right\}$ NMR (toluene- $d_{8}, 79.49 \mathrm{MHz}, 25{ }^{\circ} \mathrm{C}$ ): $\delta=-3.35 \mathrm{ppm}$. ${ }^{207} \mathrm{~Pb}\left\{{ }^{1} \mathrm{H}\right\} \quad$ NMR (toluene- $\left.d_{8}, \quad 83.71 \mathrm{MHz}, 25{ }^{\circ} \mathrm{C}\right): \delta_{\mathrm{Pb}}=$ +2007 ppm. Elemental analysis for $\mathrm{C}_{27} \mathrm{H}_{54} \mathrm{~N}_{2} \mathrm{O}_{3} \mathrm{PbSi}_{2}(718.10 \mathrm{~g}$ $\mathrm{mol}^{-1}$ ): theoretical, C $45.2 \%$, H 7.6\%, N $3.9 \%$; found C $44.9 \%$, H 7.4\%, N 3.7\%.

$\left\{\mathbf{L O}^{2}\right\} \mathbf{P b}\left(\mathbf{N}\left(\mathrm{SiMe}_{3}\right)_{2}\right)(\mathbf{1 0})$. By following a protocol similar to that described for $\mathbf{1}$, the reaction of $\left\{\mathrm{LO}^{2}\right\} \mathrm{H}(0.35 \mathrm{~g}$, $1.20 \mathrm{mmol})$ and $\mathrm{Pb}\left(\mathrm{N}\left(\mathrm{SiMe}_{3}\right)_{2}\right)_{2}(0.64 \mathrm{~g}, 1.22 \mathrm{mmol})$ afforded 10 as a colourless powder $(0.65 \mathrm{~g}, 81 \%)$. Single-crystals of 10 suitable for X-ray diffraction were obtained by recrystallisation from a cold mixture of pentane and toluene. ${ }^{1} \mathrm{H}$ NMR (toluene$\left.d_{8}, 400.13 \mathrm{MHz}, 25^{\circ} \mathrm{C}\right): \delta=7.61\left(\mathrm{~d}, 1 \mathrm{H},{ }^{4} J_{\mathrm{HH}}=2.5 \mathrm{~Hz}\right.$, aromatic- $H), 6.86\left(\mathrm{~d}, 1 \mathrm{H},{ }^{4} J_{\mathrm{HH}}=2.5 \mathrm{~Hz}\right.$, aromatic- $\left.H\right), 4.15(\mathrm{br}, 1 \mathrm{H}$, $\mathrm{ArCH}_{2} \mathrm{~N}$ ), 3.22-3.10 (br m, 2H, $\mathrm{NCH}_{2} \mathrm{CH}_{3}$ ), 2.79 (br, $1 \mathrm{H}$, $\mathrm{ArCH}_{2} \mathrm{~N}$ ), 2.44-2.33 (br m, 2H, $\left.\mathrm{NCH}_{2} \mathrm{CH}_{3}\right), 1.67$ (s, 9H, $\left.\mathrm{C}\left(\mathrm{CH}_{3}\right)_{3}\right), 1.40\left(\mathrm{~s}, 9 \mathrm{H}, \mathrm{C}\left(\mathrm{CH}_{3}\right)_{3}\right), 0.74$ and 0.57 (br m, 6H, both $\left.\mathrm{NCH}_{2} \mathrm{CH}_{3}\right), 0.39 \mathrm{ppm}\left(\mathrm{s}, 18 \mathrm{H}, \mathrm{N}\left(\mathrm{Si}\left(\mathrm{CH}_{3}\right)_{3}\right)_{2}\right) .{ }^{13} \mathrm{C}\left\{{ }^{1} \mathrm{H}\right\} \mathrm{NMR}$ (toluene- $d_{8}, 100.62 \mathrm{MHz}, 25^{\circ} \mathrm{C}$ ): $\delta=160.68,140.97,138.48$, 126.84, 124.93 and 124.79 (all aromatic-C), $56.28\left(\mathrm{ArCH}_{2} \mathrm{~N}\right)$, 46.27 and 43.68 (both $\mathrm{NCH}_{2} \mathrm{CH}_{3}$ ), 35.56 and 34.38 (both $\left.C\left(\mathrm{CH}_{3}\right)_{3}\right), 32.47$ and 30.88 (both $\left.\mathrm{C}\left(\mathrm{CH}_{3}\right)_{3}\right), 10.19$ and 7.48 (both $\left.\left.\mathrm{NCH}_{2} \mathrm{CH}_{3}\right), 7.01 \mathrm{ppm}\left(\mathrm{N}\left(\mathrm{Si}\left(\mathrm{CH}_{3}\right)_{3}\right)\right)_{2}\right){ }^{29} \mathrm{Si}\left\{{ }^{1} \mathrm{H}\right\}$ NMR (toluene- $d_{8}$, $79.49 \mathrm{MHz}, 25{ }^{\circ} \mathrm{C}$ ): $\delta=-2.35 \mathrm{ppm} .{ }^{207} \mathrm{~Pb}\left\{{ }^{1} \mathrm{H}\right\}$ NMR (toluene- $d_{8}$, $\left.83.71 \mathrm{MHz}, 25{ }^{\circ} \mathrm{C}\right): \delta=2109 \mathrm{ppm}$. Elemental analysis for $\mathrm{C}_{25} \mathrm{H}_{50} \mathrm{~N}_{2} \mathrm{OPbSi}_{2}\left(658.05 \mathrm{~g} \mathrm{~mol}^{-1}\right)$ : theoretical, C $45.6 \%$, $\mathrm{H} 7.7 \%$, N 4.3\%; found C $45.4 \%$, H 7.8\%, N 4.2\%.
$\left\{\mathbf{L O}^{3}\right\} \mathbf{P b}\left(\mathbf{N}\left(\mathrm{SiMe}_{3}\right)_{2}\right)(\mathbf{1 1})$. By following a protocol similar to that described for 1 , the reaction of $\left\{\mathrm{LO}^{3}\right\} \mathrm{H}(0.42 \mathrm{~g}$, $0.96 \mathrm{mmol})$ and $\mathrm{Pb}\left(\mathrm{N}\left(\mathrm{SiMe}_{3}\right)_{2}\right)_{2}(0.52 \mathrm{~g}, 0.96 \mathrm{mmol})$ afforded after extended work-up a mixture of $\mathbf{1 1}(90 \%)$ and $\left\{\mathrm{LO}^{3}\right\}_{2} \mathrm{~Pb}$ $(10 \%)$ which could not be purified. X-ray quality crystals of $\mathbf{1 1}$ were obtained by recrystallisation from pentane at room temperature. Spectroscopic data for $\mathbf{1 1}$ (see below for analytically pure $\left.\left\{\mathrm{LO}^{3}\right\}_{2} \mathrm{~Pb}\right):{ }^{1} \mathrm{H}$ NMR (benzene- $d_{6}, 400.13 \mathrm{MHz}, 2{ }^{\circ} \mathrm{C}$ ): $\delta=$ $7.71\left(\mathrm{~d},{ }^{4} J_{\mathrm{HH}}=2.8 \mathrm{~Hz}, 1 \mathrm{H}\right.$, aromatic- $\left.H\right), 6.98\left(\mathrm{~d},{ }^{4} J_{\mathrm{HH}}=2.8 \mathrm{~Hz}\right.$, $1 \mathrm{H}$, aromatic- $\mathrm{H}$ ), $3.87\left(\mathrm{br}, 2 \mathrm{H}, \mathrm{ArCH}_{2} \mathrm{~N}\right.$ and $\left.\mathrm{OCH}_{2}\right), 3.80-3.74$ $\left(\mathrm{m}, 2 \mathrm{H}, \mathrm{OCH}_{2}\right), 3.41-3.38\left(\mathrm{~m}, 2 \mathrm{H}, \mathrm{OCH}_{2}\right.$ and $\left.\mathrm{ArCH}_{2} \mathrm{~N}\right)$, 3.24-3.18 (m, $12 \mathrm{H}, \mathrm{OCH}_{2}$ and $\left.\mathrm{NCH}_{2} \mathrm{CH}_{2}\right), 3.03\left(\mathrm{br}, 4 \mathrm{H}, \mathrm{OCH}_{2}\right)$, $1.77\left(\mathrm{~s}, 9 \mathrm{H}, \mathrm{C}\left(\mathrm{CH}_{3}\right)_{3}\right), 1.44\left(\mathrm{~s}, 9 \mathrm{H}, \mathrm{C}\left(\mathrm{CH}_{3}\right)_{3}\right), 0.52(\mathrm{~s}, 18 \mathrm{H}, \mathrm{N}(\mathrm{Si}-$ $\left.\left.\left(\mathrm{CH}_{3}\right)_{3}\right)_{2}\right)_{2}$ ppm. ${ }^{13} \mathrm{C}\left\{{ }^{1} \mathrm{H}\right\}$ NMR (benzene- $d_{6}, 100.61 \mathrm{MHz}, 25{ }^{\circ} \mathrm{C}$ ): $\delta=161.43,141.13,138.25,127.22,125.45$ and 124.78 (all aromatic- $C), 71.35,70.83,70.58$ and $67.36\left(\mathrm{OCH}_{2}\right), 58.87$ $\left(\mathrm{ArCH} \mathrm{H}_{2} \mathrm{~N}\right), 53.51\left(\mathrm{NCH}_{2} \mathrm{CH}_{2}\right), 35.90$ and 34.60 (both $C\left(\mathrm{CH}_{3}\right)_{3}$ ), 32.81 and 31.42 (both $\left.\mathrm{C}\left(\mathrm{CH}_{3}\right)_{3}\right), 7.32\left(\mathrm{~N}\left(\mathrm{Si}\left(\mathrm{CH}_{3}\right)_{3}\right)_{2}\right)$ ppm. ${ }^{29} \mathrm{Si}-$ $\left\{{ }^{1} \mathrm{H}\right\}$ NMR (benzene- $d_{6}, 79.49 \mathrm{MHz}, 25{ }^{\circ} \mathrm{C}$ ): $\delta=-3.29 \mathrm{ppm}$. ${ }^{207} \mathrm{~Pb}\left\{{ }^{1} \mathrm{H}\right\} \mathrm{NMR}$ (benzene- $d_{6}, \quad 83.71 \mathrm{MHz}, \quad \mathrm{Pb}\left(\mathrm{N}\left(\mathrm{SiMe}_{3}\right)_{2}\right)_{2}$, $25{ }^{\circ} \mathrm{C}$ ): $\delta=+2027 \mathrm{ppm}$. Elemental analysis for $\mathrm{C}_{31} \mathrm{H}_{60} \mathrm{~N}_{2} \mathrm{O}_{5}$ $\mathrm{PbSi}_{2}$ (804.19 $\mathrm{g} \mathrm{mol}^{-1}$ ) could not be obtained owing to contamination with $\left\{\mathrm{LO}^{3}\right\}_{2} \mathrm{~Pb}$.

$\left\{\mathbf{L O}^{3}\right\}_{2} \mathbf{P b}$. A solution of $\left\{\mathrm{LO}^{3}\right\} \mathrm{H}(0.53 \mathrm{~g}, 1.21 \mathrm{mmol})$ in $\mathrm{Et}_{2} \mathrm{O}$ $(15 \mathrm{~mL})$ was added over a solution of $\mathrm{Pb}\left(\mathrm{N}\left(\mathrm{SiMe}_{3}\right)_{2}\right)_{2}(0.32 \mathrm{~g}$, $0.60 \mathrm{mmol})$ in $\mathrm{Et}_{2} \mathrm{O}(15 \mathrm{~mL})$. Within seconds, a white precipitate was formed. The reaction mixture was stirred overnight. The precipitate was isolated by filtration, washed with $\mathrm{Et}_{2} \mathrm{O}$ $(3 \times 5 \mathrm{~mL})$ and dried under reduced pressure to give $\left\{\mathrm{LO}^{3}\right\}_{2} \mathrm{~Pb}$ $(0.39 \mathrm{~g}, 60 \%)$ as a colourless solid. Single-crystals of $\left\{\mathrm{LO}^{3}\right\}_{2} \mathrm{~Pb} \cdot \mathrm{C}_{6} \mathrm{H}_{6}$ were grown from benzene and their structure was determined. ${ }^{1} \mathrm{H}$ NMR (benzene- $d_{6}, 500.25 \mathrm{MHz}, 25{ }^{\circ} \mathrm{C}$ ): $\delta=$ $7.80\left(\mathrm{~d},{ }^{4} J_{\mathrm{HH}}=3.0 \mathrm{~Hz}, 1 \mathrm{H}\right.$, aromatic- $\left.H\right), 7.40\left(\mathrm{~d},{ }^{4} J_{\mathrm{HH}}=3.0 \mathrm{~Hz}\right.$, $1 \mathrm{H}$, aromatic- $H$ ), $5.45\left(\mathrm{br}, 1 \mathrm{H}, \mathrm{ArCH}_{2} \mathrm{~N}\right), 3.54-2.93(\mathrm{~m} \mathrm{br}, 21 \mathrm{H}$, $\mathrm{ArCH}_{2} \mathrm{~N}, \mathrm{OCH}_{2}$ and $\left.\mathrm{NCH}_{2} \mathrm{CH}_{2}\right), 1.85\left(\mathrm{~s}, 9 \mathrm{H}, \mathrm{C}\left(\mathrm{CH}_{3}\right)_{3}\right), 1.52(\mathrm{~s}$, 9H, C $\left(\mathrm{CH}_{3}\right)_{3}$ ) ppm. ${ }^{13} \mathrm{C}\left\{{ }^{1} \mathrm{H}\right\}$ NMR (benzene- $d_{6}, 125.76 \mathrm{MHz}$, $\left.25{ }^{\circ} \mathrm{C}\right): \delta=164.15,138.45,135.16,128.79,128.16$ and 124.40 (all aromatic- $C$ ), 70.72, 70.55 (br), 69.98 (br), 68.79 (all $\mathrm{NCH}_{2} \mathrm{CH}_{2}$ and $\left.\mathrm{OCH}_{2}\right), 61.13\left(\mathrm{ArCH}_{2} \mathrm{~N}\right), 36.06$ and 34.57 (both $\left.\mathrm{C}\left(\mathrm{CH}_{3}\right)_{3}\right), 32.93\left(\mathrm{C}\left(\mathrm{CH}_{3}\right)_{3}\right)$ and 30.94 (both $\left.\mathrm{C}\left(\mathrm{CH}_{3}\right)_{3}\right) \mathrm{ppm} .{ }^{207} \mathrm{~Pb}$ NMR (benzene- $\left.d_{6}, 83.71 \mathrm{MHz}, 60{ }^{\circ} \mathrm{C}\right): \delta=-367 \mathrm{ppm}$. Elemental analysis for $\mathrm{C}_{50} \mathrm{H}_{84} \mathrm{~N}_{2} \mathrm{O}_{10} \mathrm{~Pb}\left(1080.41 \mathrm{~g} \mathrm{~mol}^{-1}\right)$ : theoretical, C 55.6\%, H 7.8\%, N 2.6\%; found C 55.5\%, H 7.8\%, N 2.6\%.

$\left\{\mathbf{L O}^{3}\right\} \mathbf{H} \cdot \mathbf{L i O T f}$. In a Schlenk vessel, a mixture of LiOTf $(0.25 \mathrm{~g}, 1.60 \mathrm{mmol})$ and $\left\{\mathrm{LO}^{3}\right\} \mathrm{H}(0.72 \mathrm{~g}, 1.65 \mathrm{mmol})$ was suspended in diethyl ether $(20 \mathrm{~mL})$. Upon stirring at room temperature, all LiOTf dissolved to give a clean, colourless solution. The volatiles were then removed under vacuum to quantitatively give analytically pure $\left\{\mathbf{L O}^{3}\right\} \mathbf{H} \cdot \mathbf{L i O T f}(0.97 \mathrm{~g}, 100 \%)$ as a colourless powder. Crystals suitable for X-ray diffraction studies of the title compound were rapidly obtained upon layering a hot solution in diethyl ether with pentane and gentle cooling to room temperature. ${ }^{1} \mathrm{H}$ NMR (benzene- $d_{6}$, $\left.400.13 \mathrm{MHz}, 25{ }^{\circ} \mathrm{C}\right): \delta=10.01(\mathrm{~s}, 1 \mathrm{H}$, aromatic-OH), $7.47(\mathrm{~d}$, ${ }^{4} J_{\mathrm{HH}}=4.0 \mathrm{~Hz}, 1 \mathrm{H}$, aromatic- $\left.H\right), 6.89\left(\mathrm{~d},{ }^{4} J_{\mathrm{HH}}=4.0 \mathrm{~Hz}, 1 \mathrm{H}\right.$, aromatic- $H), \quad 3.40-3.15\left(\mathrm{~m}, \quad 18 \mathrm{H}, \quad \mathrm{ArCH}_{2} \mathrm{~N}, \quad \mathrm{OCH}_{2}\right.$ and 
Table 5 Summary of crystallographic data for 1-3

\begin{tabular}{|c|c|c|c|}
\hline & $\begin{array}{l}\left\{\mathrm{LO}^{1}\right\} \mathrm{Ge}\left(\mathrm{N}\left(\mathrm{SiMe}_{3}\right)_{2}\right) \\
\mathbf{1}\end{array}$ & $\begin{array}{l}\left\{\mathrm{LO}^{2}\right\} \mathrm{Ge}\left(\mathrm{N}\left(\mathrm{SiMe}_{3}\right)_{2}\right) \\
\text {. }\end{array}$ & 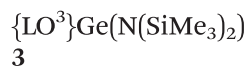 \\
\hline Formula & $\mathrm{C}_{27} \mathrm{H}_{54} \mathrm{GeN}_{2} \mathrm{O}_{3} \mathrm{Si}_{2}$ & $\mathrm{C}_{25} \mathrm{H}_{50} \mathrm{GeN}_{2} \mathrm{OSi}_{2}$ & $\mathrm{C}_{31} \mathrm{H}_{60} \mathrm{GeN}_{2} \mathrm{O}_{5} \mathrm{Si}_{2}$ \\
\hline CCDC & 942087 & 942089 & 942093 \\
\hline Mol. wt. & 583.49 & 523.44 & 669.63 \\
\hline Crystal system & Monoclinic & Triclinic & Monoclinic \\
\hline Space group & $P 2_{1} / n$ & $P \overline{1}$ & $P 2_{1} / n$ \\
\hline$a(\AA)$ & $13.4042(4)$ & $10.4714(6)$ & $13.0369(18)$ \\
\hline$b(\AA)$ & $17.7120(4)$ & $12.3029(8)$ & $15.596(2)$ \\
\hline$c(\AA)$ & $13.8889(4)$ & $12.3573(6)$ & $18.084(3)$ \\
\hline$\alpha\left(^{\circ}\right)$ & 90 & $81.087(3)$ & 90 \\
\hline$\beta\left({ }^{\circ}\right)$ & $99.1210(10)$ & $75.381(2)$ & $98.921(6)$ \\
\hline$\gamma\left({ }^{\circ}\right)$ & 90 & $86.021(3)$ & 90 \\
\hline$V\left(\AA^{3}\right)$ & $3255.74(15)$ & $1521.07(15)$ & $3632.4(9)$ \\
\hline$Z$ & 4 & 2 & 4 \\
\hline Density $\left(\mathrm{g} \mathrm{cm}^{-3}\right)$ & 1.19 & 1.143 & 1.224 \\
\hline Abs. coeff. $\left(\mathrm{mm}^{-1}\right)$ & 1.042 & 1.103 & 0.947 \\
\hline$F(000)$ & 1256 & 564 & 1440 \\
\hline Crystal size (mm) & $0.6 \times 0.3 \times 0.25$ & $0.32 \times 0.23 \times 0.15$ & $0.17 \times 0.12 \times 0.07$ \\
\hline$\theta$ Range $\left(^{\circ}\right)$ & 3.02 to 27.48 & 2.95 to 27.49 & 3.05 to 27.48 \\
\hline \multirow[t]{3}{*}{ Limiting indices } & $-17<h<17$ & $-13<h<13$ & $-16<h<14$ \\
\hline & $-2<k<22$ & $-15<k<15$ & $-17<k<20$ \\
\hline & $-14<l<18$ & $-16<l<16$ & $-22<l<23$ \\
\hline$R(\mathrm{int})$ & 0.0388 & 0.0465 & 0.0355 \\
\hline Reflections collected & 19774 & 25015 & 29717 \\
\hline Reflec. unique $[I>2 \sigma(I)]$ & 5797 & 5730 & 8212 \\
\hline Completeness to $\theta$ & 0.995 & 0.993 & 0.987 \\
\hline Data/restraints/param. & $7420 / 0 / 330$ & $6928 / 0 / 294$ & $8212 / 0 / 382$ \\
\hline Goodness-of-fit & 1.051 & 1.064 & 1.021 \\
\hline$R_{1}[I>2 \sigma(I)]$ (all data) & $0.0512(0.123)$ & $0.0352(0.0777)$ & $0.0287(0.0388)$ \\
\hline $\mathrm{wR}_{2}[I>2 \sigma(I)]$ (all data) & $0.0697(0.1325)$ & $0.0465(0.0818)$ & $0.0675(0.0719)$ \\
\hline Largest diff. e $\mathrm{A}^{-3}$ & 1.723 and -0.777 & 0.431 and $-0.271^{3}$ & 0.371 and -0.212 \\
\hline
\end{tabular}

Table 6 Summary of crystallographic data for 9-11 and $\left\{\mathrm{LO}^{3}\right\}_{2} \mathrm{~Pb} \cdot \mathrm{C}_{6} \mathrm{H}_{6}$

\begin{tabular}{|c|c|c|c|c|}
\hline & $\left\{\mathrm{LO}^{3}\right\}_{2} \mathrm{~Pb} \cdot \mathrm{C}_{6} \mathrm{H}_{6}$ & $\left\{\mathrm{LO}^{1}\right\} \mathrm{Pb}\left(\mathrm{N}\left(\mathrm{SiMe}_{3}\right)_{2}\right) 9$ & $\left\{\mathrm{LO}^{2}\right\} \mathrm{Pb}\left(\mathrm{N}\left(\mathrm{SiMe}_{3}\right)_{2}\right) \mathbf{1 0}$ & $\left\{\mathrm{LO}^{3}\right\} \mathrm{Pb}\left(\mathrm{N}\left(\mathrm{SiMe}_{3}\right)_{2}\right) \mathbf{1 1}$ \\
\hline Formula & $\mathrm{C}_{56} \mathrm{H}_{90} \mathrm{~N}_{2} \mathrm{O}_{10} \mathrm{~Pb}$ & $\mathrm{C}_{27} \mathrm{H}_{54} \mathrm{~N}_{2} \mathrm{O}_{3} \mathrm{PbSi}_{2}$ & $\mathrm{C}_{25} \mathrm{H}_{50} \mathrm{~N}_{2} \mathrm{O}_{1} \mathrm{PbSi}_{2}$ & $\mathrm{C}_{31} \mathrm{H}_{60} \mathrm{~N}_{2} \mathrm{O}_{5} \mathrm{PbSi}_{2}$ \\
\hline CCDC & 942091 & 942088 & 942090 & 942096 \\
\hline Mol. wt. & 1158.49 & 718.09 & 658.04 & 804.19 \\
\hline Crystal system & Monoclinic & Triclinic & Triclinic & Triclinic \\
\hline Space group & $P 2_{1} / n$ & $P \overline{1}$ & $P \overline{1}$ & $P \overline{1}$ \\
\hline$a(\AA)$ & $14.0101(4)$ & $10.5521(10)$ & $10.5366(4)$ & $12.1963(3)$ \\
\hline$b(\AA)$ & $27.8363(7)$ & $13.7269(13)$ & $11.8539(4)$ & $12.2480(4)$ \\
\hline$c(\AA)$ & $14.9256(4)$ & $15.0466(12)$ & $12.2084(4)$ & $14.3540(3)$ \\
\hline$\alpha\left({ }^{\circ}\right)$ & 90 & $64.082(3)$ & $87.436(2)$ & $66.5600(10)$ \\
\hline$\beta\left({ }^{\circ}\right)$ & $101.4870(10)$ & $69.863(3)$ & $81.9730(10)$ & $68.9620(10)$ \\
\hline$\gamma\left({ }^{\circ}\right)$ & 90 & $81.892(3)$ & $87.2970(10)$ & $75.4680(10)$ \\
\hline$V\left(\AA^{3}\right)$ & $5704.2(3)$ & $1840.3(3)$ & $1507.08(9)$ & $1821.43(8)$ \\
\hline$Z$ & 4 & 2 & 2 & 2 \\
\hline Density $\left(\mathrm{g} \mathrm{cm}^{-3}\right)$ & 1.349 & 1.296 & 1.45 & 1.466 \\
\hline Abs. coeff. $\left(\mathrm{mm}^{-1}\right)$ & 3.013 & 4.673 & 5.694 & 4.734 \\
\hline$F(000)$ & 2408 & 728 & 664 & 820 \\
\hline Crystal size (mm) & $0.35 \times 0.1 \times 0.09$ & $0.1 \times 0.1 \times 0.1$ & $0.26 \times 0.21 \times 0.12$ & $0.54 \times 0.23 \times 0.19$ \\
\hline$\theta$ Range $\left(^{\circ}\right)$ & 2.93 to 27.44 & 2.93 to 27.49 & 3.04 to 27.48 & 2.96 to 27.48 \\
\hline \multirow[t]{3}{*}{ Limiting indices } & $-16<h<18$ & $-13<h<13$ & $-13<h<13$ & $-15<h<15$ \\
\hline & $-33<k<36$ & $-17<k<17$ & $-13<k<15$ & $-15<k<15$ \\
\hline & $-19<l<19$ & $-19<l<19$ & $-15<l<15$ & $-17<l<18$ \\
\hline$R(\mathrm{int})$ & 0.0354 & 0.052 & 0.0367 & 0.0413 \\
\hline Reflections collected & 48821 & 17711 & 15900 & 20820 \\
\hline Reflec. unique $[I>2 \sigma(I)]$ & 12869 & 6343 & 5938 & 8228 \\
\hline Completeness to $\theta$ & 0.988 & 0.973 & 0.985 & 0.985 \\
\hline Data/restraints/param. & $12869 / 0 / 634$ & $8232 / 0 / 330$ & $6818 / 0 / 294$ & $8228 / 0 / 382$ \\
\hline Goodness-of-fit & 1.012 & 0.998 & 1.009 & 1.012 \\
\hline$R_{1}[I>2 \sigma(I)]$ (all data) & $0.029(0.046)$ & $0.0499(0.1108)$ & $0.0306(0.0547)$ & $0.0269(0.0321)$ \\
\hline $\mathrm{wR}_{2}[I>2 \sigma(I)]$ (all data) & $0.0572(0.0617)$ & $0.0693(0.1172)$ & $0.0391(0.0569)$ & $0.0558(0.0574)$ \\
\hline Largest diff. e $\mathrm{A}^{-3}$ & 0.918 and -0.81 & 2.093 and -2.096 & 0.9 and -0.9 & 0.6 and -1.159 \\
\hline
\end{tabular}


Table 7 Summary of crystallographic data for $\mathbf{8},\left\{\mathrm{LO}^{3}\right\} \mathrm{GeCl}$ and $\left\{\mathrm{LO}^{3}\right\} \mathrm{SnCl}$

\begin{tabular}{|c|c|c|c|}
\hline & $\left\{\mathrm{LO}^{4}\right\} \mathrm{Sn}\left(\mathrm{N}\left(\mathrm{SiMe}_{3}\right)_{2} 8\right.$ & $\left\{\mathrm{LO}^{3}\right\} \mathrm{SnCl}$ & $\left\{\mathrm{LO}^{3}\right\} \mathrm{GeCl}$ \\
\hline Formula & $\mathrm{C}_{29} \mathrm{H}_{56} \mathrm{~N}_{2} \mathrm{O}_{4} \mathrm{Si}_{2} \mathrm{Sn}$ & $\mathrm{C}_{25} \mathrm{H}_{42} \mathrm{ClNO}_{5} \mathrm{Sn}$ & $\mathrm{C}_{25} \mathrm{H}_{42} \mathrm{ClGeNO}_{5}$ \\
\hline CCDC & 942099 & 942097 & 942092 \\
\hline Mol. wt. & 671.63 & 590.74 & 544.64 \\
\hline Crystal system & Triclinic & Monoclinic & Monoclinic \\
\hline Space group & $P \overline{1}$ & $P 2_{1} / n$ & $P 2_{1} / n$ \\
\hline$a(\AA)$ & $10.7245(3)$ & $14.4474(6)$ & $14.4685(7)$ \\
\hline$b(\AA)$ & $13.2277(4)$ & $10.9372(5)$ & $10.9550(5)$ \\
\hline$c(\AA)$ & $13.3588(4)$ & $18.6881(7)$ & $18.4462(10)$ \\
\hline$\alpha\left(^{\circ}\right)$ & $70.5920(10)$ & 90 & 90 \\
\hline$\beta\left({ }^{\circ}\right)$ & $85.7950(10)$ & $111.8890(10)$ & $112.213(2)$ \\
\hline$\gamma\left({ }^{\circ}\right)$ & $77.0520(10)$ & 90 & 90 \\
\hline$V\left(\AA^{3}\right)$ & $1741.95(9)$ & $2740.1(2)$ & $2706.8(2)$ \\
\hline$Z$ & 2 & 4 & 4 \\
\hline Density $\left(\mathrm{g} \mathrm{cm}^{-3}\right)$ & 1.28 & 1.432 & 1.336 \\
\hline Abs. coeff. $\left(\mathrm{mm}^{-1}\right)$ & 0.834 & 1.063 & 1.264 \\
\hline$F(000)$ & 708 & 1224 & 1152 \\
\hline Crystal size (mm) & $0.38 \times 0.34 \times 0.14$ & $0.56 \times 0.18 \times 0.08$ & $0.6 \times 0.12 \times 0.04$ \\
\hline$\theta$ Range $\left(^{\circ}\right)$ & 2.97 to 27.46 & 2.91 to 27.48 & 2.93 to 27.48 \\
\hline \multirow[t]{3}{*}{ Limiting indices } & $-12<h<13$ & $-18<h<18$ & $-18<h<17$ \\
\hline & $-17<k<17$ & $-12<k<14$ & $-12<k<14$ \\
\hline & $-17<l<17$ & $-17<l<24$ & $-23<l<23$ \\
\hline$R(\mathrm{int})$ & 0.0243 & 0.0435 & 0.0538 \\
\hline Reflections collected & 21981 & 22244 & 23337 \\
\hline Reflec. unique $[I>2 \sigma(I)]$ & 7123 & 5399 & 4638 \\
\hline Completeness to $\theta$ & 0.98 & 0.996 & 0.999 \\
\hline Data/restraints/param. & $7802 / 0 / 355$ & $6259 / 0 / 304$ & $6197 / 0 / 308$ \\
\hline Goodness-of-fit & 1.026 & 1.024 & 1.081 \\
\hline$R_{1}[I>2 \sigma(I)]$ (all data) & $0.0219(0.05)$ & $0.0307(0.0707)$ & $0.0412(0.1005)$ \\
\hline $\mathrm{w}_{2}[I>2 \sigma(I)]$ (all data) & $0.0258(0.0516)$ & $0.0384(0.0748)$ & $0.065(0.1164)$ \\
\hline Largest diff. e $\mathrm{A}^{-3}$ & 0.338 and -0.272 & 1.418 and -0.574 & 1.087 and -0.862 \\
\hline
\end{tabular}

$\mathrm{NCH}_{2} \mathrm{CH}_{2}$ ), 2.37 (br s, $\left.4 \mathrm{H}, \mathrm{OCH}_{2}\right), 1.57$ (s, 9H, C(CH $\left.\mathrm{CH}_{3}\right), 1.37$ (s, 9H, $\left.\mathrm{C}\left(\mathrm{CH}_{3}\right)_{3}\right)$ ppm. ${ }^{13} \mathrm{C}\left\{{ }^{1} \mathrm{H}\right\}$ NMR (benzene- $d_{6}, 100.62 \mathrm{MHz}$, $\left.25^{\circ} \mathrm{C}\right): \delta=154.37(i-C), 141.09(p-C), 135.72(o-C), 124.20(o-C)$, $123.15(m-C), 122.26(m-C), 121.3\left(\mathrm{q}, C_{3},{ }^{1} J_{\mathrm{CF}}=319 \mathrm{~Hz}\right), 68.93$, 68.10, 67.65, and $66.89\left(\right.$ all $\left.\mathrm{OCH}_{2}\right), 58.01\left(\mathrm{ArCH}_{2} \mathrm{~N}\right), 50.90$ $\left(\mathrm{NCH}_{2} \mathrm{CH}_{2}\right), 35.20$ and 34.38 (both $\left.C\left(\mathrm{CH}_{3}\right)_{3}\right), 31.99$ and 29.99 (both $\left.\mathrm{C}\left(\mathrm{CH}_{3}\right)_{3}\right) .{ }^{7} \mathrm{Li} \mathrm{NMR}\left(155.51 \mathrm{MHz}, 25{ }^{\circ} \mathrm{C}\right)$ : in benzene- $d_{6}$, $\delta=-0.96 \mathrm{ppm}$; in dichloromethane- $d_{2},-0.84 \mathrm{ppm} .{ }^{19} \mathrm{~F}$ NMR (benzene- $d_{6}, 376.45 \mathrm{MHz}, 25{ }^{\circ} \mathrm{C}$ ): $\delta=-77.98$ (s, 3F) ppm. Elemental analysis for $\mathrm{C}_{26} \mathrm{H}_{43} \mathrm{~F}_{3} \mathrm{LiNO}_{8} \mathrm{~S}\left(593.62 \mathrm{~g} \mathrm{~mol}^{-1}\right)$ : theoretical, C $52.6 \%, \mathrm{H} 7.3 \%, \mathrm{~N} 2.4 \%$; found C $52.7 \%, \mathrm{H} 7.2 \%$, $\mathrm{N} 2.4 \%$.

$\left\{\mathbf{L O}^{3}\right\} \mathrm{Ge}\left(\mathbf{N}\left(\mathrm{SiMe}_{3}\right)_{2}\right) \cdot$ LiOTf (3·LiOTf). $\mathrm{CF}_{3} \mathrm{SO}_{3} \mathrm{Li} \quad(47 \mathrm{mg}$, $0.29 \mathrm{mmol})$ was added to a solution of $\left\{\mathrm{LO}^{3}\right\} \mathrm{Ge}\left(\mathrm{N}\left(\mathrm{SiMe}_{3}\right)_{2}\right)$ $(0.20 \mathrm{~g}, 0.3 \mathrm{mmol})$ in $\mathrm{Et}_{2} \mathrm{O}(15 \mathrm{~mL})$. After stirring the reaction mixture for $30 \mathrm{~min}$, the volatiles were removed in vacuo to afford 3.LiOTf $(220 \mathrm{mg}, 89 \%)$ as a white powder. The compound still contained $c a .8 \%$ of $\left\{\mathrm{LO}^{3}\right\} \mathrm{H} \cdot \mathrm{LiOTf}$ and the mixture could not be further separated. A small crop of X-ray quality crystals of 3-LiOTf was grown by recrystallisation from a concentrated diethyl ether solution at room temperature. ${ }^{1} \mathrm{H}$ NMR (benzene- $\left.d_{6}, 400.13 \mathrm{MHz}, 25^{\circ} \mathrm{C}\right): \delta=7.61\left(\mathrm{~d},{ }^{4} J_{\mathrm{HH}}=1.8 \mathrm{~Hz}, 1 \mathrm{H}\right.$, aromatic- $H), 7.18\left(\mathrm{~d},{ }^{4} J_{\mathrm{HH}}=1.8 \mathrm{~Hz}, 1 \mathrm{H}\right.$, aromatic- $\left.H\right), 3.86-3.09$ (br m, 22H, $\mathrm{ArCH}_{2} \mathrm{~N}, \mathrm{NCH}_{2} \mathrm{CH}_{2}$ and $\left.\mathrm{OCH}_{2}\right), 1.65(\mathrm{~s}, 9 \mathrm{H}$, $\left.\mathrm{C}\left(\mathrm{CH}_{3}\right)_{3}\right), 1.39\left(\mathrm{~s}, 9 \mathrm{H}, \mathrm{C}\left(\mathrm{CH}_{3}\right)_{3}\right), 0.43$ (br s, $\left.18 \mathrm{H}, \mathrm{N}\left(\mathrm{Si}\left(\mathrm{CH}_{3}\right)_{3}\right)_{2}\right)$. ${ }^{13} \mathrm{C}\left\{{ }^{1} \mathrm{H}\right\}$ NMR (benzene- $d_{6}-1,2-\mathrm{C}_{6} \mathrm{H}_{4} \mathrm{~F}_{2}=5: 2,100.62 \mathrm{MHz}$, $\left.25{ }^{\circ} \mathrm{C}\right): \delta=156.84,142.48,141.62,128.79,127.45$ and 125.92 (all aromatic- $C$ ), 121.00 (q, $C \mathrm{~F}_{3},{ }^{1} J_{\mathrm{CF}}=320 \mathrm{~Hz}$ ), 70.26-70.01, 68.14-67.96 and 67.49-67.37 (all $\mathrm{NCH}_{2} \mathrm{CH}_{2}, \mathrm{OCH}_{2}$ ), 56.82 $\left(\mathrm{ArCH}_{2} \mathrm{~N}\right), 35.64$ and 34.92 (both $\left.\mathrm{C}\left(\mathrm{CH}_{3}\right)_{3}\right), 32.32$ and 31.19 (both $\left.\mathrm{C}\left(\mathrm{CH}_{3}\right)_{3}\right), 7.34$ and 6.03 (br, both $\left.\mathrm{N}\left(\mathrm{Si}\left(\mathrm{CH}_{3}\right)_{3}\right)_{2}\right)$ ppm. ${ }^{29} \mathrm{Si}\left\{{ }^{1} \mathrm{H}\right\}$ NMR (toluene- $d_{8}, 79.49 \mathrm{MHz}, 40{ }^{\circ} \mathrm{C}$ ): $\delta=+0.70 \mathrm{ppm}$. ${ }^{7} \mathrm{Li}$ NMR (benzene- $d_{6}, 155.51 \mathrm{MHz}, 25{ }^{\circ} \mathrm{C}$ ): $\delta=-0.74 \mathrm{ppm} .{ }^{19} \mathrm{~F}$ NMR (benzene- $d_{6}, 376.45 \mathrm{MHz}, 25^{\circ} \mathrm{C}$ ): $\delta=-77.92(\mathrm{~s}, 3 \mathrm{~F}) \mathrm{ppm}$. Elemental analysis for $\mathrm{C}_{32} \mathrm{H}_{60} \mathrm{~F}_{3} \mathrm{GeLiN}_{2} \mathrm{O}_{8} \mathrm{SSi}_{2}\left(825.64 \mathrm{~g} \mathrm{~mol}^{-1}\right.$ ) could not be obtained owing to contamination with $\left\{\mathrm{LO}^{3}\right\}$ $\mathrm{H} \cdot \mathrm{LiOTf}$.

$\left\{\mathbf{L O}^{3}\right\} \mathbf{S n}\left(\mathbf{N}\left(\mathrm{SiMe}_{3}\right)_{2}\right) \cdot \mathbf{L i O T f} \quad$ (7·LiOTf). $\mathrm{CF}_{3} \mathrm{SO}_{3} \mathrm{Li} \quad(47 \mathrm{mg}$, $0.29 \mathrm{mmol}$ ) was added in portions with a bent finger to a solution of $\left\{\mathrm{LO}^{3}\right\} \mathrm{Sn}\left(\mathrm{N}\left(\mathrm{SiMe}_{3}\right)_{2}\right)(0.21 \mathrm{~g}, 0.3 \mathrm{mmol})$ in $\mathrm{Et}_{2} \mathrm{O}(20 \mathrm{~mL})$. After stirring the reaction mixture for $30 \mathrm{~min}$, the volatiles were removed at low pressure to afford 7.LiOTf $(200 \mathrm{mg}, 78 \%)$ as a white powder. Single crystals of 7 -LiOTf were obtained by recrystallisation from a mixture of THF and toluene at room temperature. ${ }^{1} \mathrm{H}$ NMR $\left(\mathrm{CD}_{2} \mathrm{Cl}_{2}, 500.13 \mathrm{MHz}, 25{ }^{\circ} \mathrm{C}\right): \delta=7.34(\mathrm{~d}$, $\left.{ }^{4} J_{\mathrm{HH}}=2.5 \mathrm{~Hz}, 1 \mathrm{H}\right), 6.95\left(\mathrm{~d},{ }^{4} J_{\mathrm{HH}}=2.5 \mathrm{~Hz}, 1 \mathrm{H}\right), 4.34-3.14(\mathrm{br} \mathrm{m}$, $24 \mathrm{H}, \mathrm{ArCH}_{2} \mathrm{~N}, \mathrm{OCH}_{2}$ and $\left.\mathrm{NCH}_{2} \mathrm{CH}_{2}\right), 1.43\left(\mathrm{~s}, 9 \mathrm{H}, \mathrm{C}\left(\mathrm{CH}_{3}\right)_{3}\right), 1.29$ (s, 9H, C $\left.\left(\mathrm{CH}_{3}\right)_{3}\right), 0.27\left(\mathrm{~s}, 18 \mathrm{H}, \mathrm{N}\left(\mathrm{Si}\left(\mathrm{CH}_{3}\right)_{3}\right)_{2}\right) \mathrm{ppm} .{ }^{13} \mathrm{C}\left\{{ }^{1} \mathrm{H}\right\}$ NMR $\left(\mathrm{CD}_{2} \mathrm{Cl}_{2}, 125.76 \mathrm{MHz}, 25{ }^{\circ} \mathrm{C}\right): \delta=158.44,140.51$, $129.39,127.40,125.25$ and 124.15 (all aromatic- $C$ ), 120.79 $\left(\mathrm{q}, \mathrm{CF}_{3},{ }^{1} J_{\mathrm{CF}}=319 \mathrm{~Hz}\right), 70.21$ and $67.94\left(\mathrm{br}, \mathrm{OCH}_{2}\right.$ and $\left.\mathrm{NCH}_{2} \mathrm{CH}_{2}\right), 56.62\left(\mathrm{ArCH}_{2} \mathrm{~N}\right), 35.08$ and 34.39 (both $\left.\mathrm{C}\left(\mathrm{CH}_{3}\right)_{3}\right)$, 31.80 and 30.30 (both $\left.\mathrm{C}\left(\mathrm{CH}_{3}\right)_{3}\right), 6.44\left(\mathrm{~N}\left(\mathrm{Si}\left(\mathrm{CH}_{3}\right)_{3}\right)_{2}\right)$ ppm. ${ }^{119} \mathrm{Sn}\left\{{ }^{1} \mathrm{H}\right\}$ NMR $\left(\mathrm{CD}_{2} \mathrm{Cl}_{2}, 149.20 \mathrm{MHz}, 25{ }^{\circ} \mathrm{C}\right): \delta=-45.8 \mathrm{ppm}$; 
Table 8 Summary of crystallographic data for $\left\{\right.$ LO $\left.^{3}\right\}$ H.LiOTf, 3.LiOTf and 7.LiOTf

\begin{tabular}{|c|c|c|c|}
\hline & $\left\{\mathrm{LO}^{3}\right\} \mathrm{H} \cdot \mathrm{LiOTf}$ & $\begin{array}{l}\left\{\mathrm{LO}^{3}\right\} \mathrm{Ge}\left(\mathrm{N}\left(\mathrm{SiMe}_{3}\right)_{2}\right) \cdot \mathrm{CF}_{3} \mathrm{SO}_{3} \mathrm{Li} \\
\text { 3.LiOTf }\end{array}$ & $\begin{array}{l}\left\{\mathrm{LO}^{3}\right\} \mathrm{Sn}\left(\mathrm{N}\left(\mathrm{SiMe}_{3}\right)_{2}\right) \cdot \mathrm{CF}_{3} \mathrm{SO}_{3} \mathrm{Li} \\
\text { 7.LiOTf }\end{array}$ \\
\hline Formula & $\mathrm{C}_{26} \mathrm{H}_{43} \mathrm{~F}_{3} \mathrm{LiNO}_{8} \mathrm{~S}$ & $\mathrm{C}_{32} \mathrm{H}_{60} \mathrm{~F}_{3} \mathrm{GeLiN}_{2} \mathrm{O}_{8} \mathrm{SSi}_{2}$ & $\mathrm{C}_{32} \mathrm{H}_{60} \mathrm{~F}_{3} \mathrm{LiN}_{2} \mathrm{O}_{8} \mathrm{SSi}_{2} \mathrm{Sn}$ \\
\hline CCDC & 942095 & 942094 & 942098 \\
\hline Mol. wt. & 593.61 & 825.59 & 871.69 \\
\hline Crystal system & Monoclinic & Triclinic & Triclinic \\
\hline Space group & $P 2_{1} / n$ & $P \overline{1}$ & $P \overline{1}$ \\
\hline$a(\AA)$ & $9.4732(13)$ & $9.1913(2)$ & $8.8219(2)$ \\
\hline$b(\AA)$ & $27.781(4)$ & $11.3799(2)$ & $11.8940(2)$ \\
\hline$c(\AA)$ & $12.5458(14)$ & $21.3025(4)$ & $21.6592(3)$ \\
\hline$\alpha\left(^{\circ}\right)$ & 90 & $97.0250(10)$ & $74.5550(10)$ \\
\hline$\beta\left({ }^{\circ}\right)$ & $109.382(6)$ & $100.1770(10)$ & $78.5080(10)$ \\
\hline$\gamma\left(0^{\circ}\right)$ & 90 & $98.1600(10)$ & $80.5870(10)$ \\
\hline$V\left(\AA^{3}\right)$ & $3114.6(7)$ & $2145.92(7)$ & $2131.92(7)$ \\
\hline$Z$ & 4 & 2 & 2 \\
\hline Density $\left(\mathrm{g} \mathrm{cm}^{-3}\right)$ & 1.266 & 1.278 & 1.358 \\
\hline Abs. coeff. $\left(\mathrm{mm}^{-1}\right)$ & 0.166 & 0.875 & 0.762 \\
\hline Crystal size (mm) & $0.58 \times 0.46 \times 0.21$ & $0.18 \times 0.12 \times 0.07$ & $0.35 \times 0.18 \times 0.12$ \\
\hline$\theta$ Range $\left(^{\circ}\right)$ & 1.47 to 27.46 & 2.91 to 27.46 & 2.92 to 27.48 \\
\hline \multirow[t]{3}{*}{ Limiting indices } & $-12<h<11$ & $-11<h<11$ & $-11<h<11$ \\
\hline & $0<k<36$ & $-14<k<14$ & $-15<k<15$ \\
\hline & $0<l<16$ & $-27<l<27$ & $-24<l<28$ \\
\hline$R($ int $)$ & 0.0000 & 0.0334 & 0.0329 \\
\hline Reflections collected & 7023 & 34506 & 22861 \\
\hline Reflec. unique $[I>2 \sigma(I)]$ & 7023 & 9720 & 8442 \\
\hline Completeness to $\theta$ & 0.980 & 0.991 & 0.988 \\
\hline Data/restraints/param. & $7023 / 0 / 382$ & $9720 / 0 / 463$ & $9691 / 0 / 463$ \\
\hline Goodness-of-fit & 1.078 & 1.032 & 1.023 \\
\hline$R_{1}[I>2 \sigma(I)]$ (all data) & $0.0590(0.0847)$ & $0.0332(0.0448)$ & $0.0324(0.0706)$ \\
\hline $\mathrm{w} R_{2}[I>2 \sigma(I)]$ (all data) & $0.1599(0.1817)$ & $0.0763(0.0813)$ & $0.0397(0.0742)$ \\
\hline Largest diff. e $\mathrm{A}^{-3}$ & 0.391 and -0.488 & 0.491 and -0.341 & 0.439 and -0.355 \\
\hline
\end{tabular}

${ }^{7} \mathrm{Li}\left\{{ }^{1} \mathrm{H}\right\} \mathrm{NMR}\left(\mathrm{CD}_{2} \mathrm{Cl}_{2}, 155.51 \mathrm{MHz}, 25^{\circ} \mathrm{C}\right): \delta=-0.56 \mathrm{ppm} .{ }^{19} \mathrm{~F}$ NMR (376.45 MHz, $\left.\mathrm{C}_{6} \mathrm{D}_{6}, 25{ }^{\circ} \mathrm{C}\right) \delta=-78.78(\mathrm{~s}, 3 \mathrm{~F}) \mathrm{ppm} .{ }^{29} \mathrm{Si}-$ $\left\{{ }^{1} \mathrm{H}\right\}$ NMR $\left(\mathrm{CD}_{2} \mathrm{Cl}_{2}, 79.49 \mathrm{MHz}, 25{ }^{\circ} \mathrm{C}\right): \delta=-0.31 \mathrm{ppm}$. Elemental analysis for $\mathrm{C}_{32} \mathrm{H}_{60} \mathrm{~F}_{3} \mathrm{LiN}_{2} \mathrm{O}_{8} \mathrm{SSi}_{2} \mathrm{Sn}\left(871.71 \mathrm{~g} \mathrm{~mol}^{-1}\right)$ : theoretical, C $44.1 \%$, H $6.9 \%$, N 3.2\%; found C $44.0 \%, \mathrm{H} 6.9 \%, \mathrm{~N}$ $3.3 \%$.

\section{Typical polymerisation procedure}

In the glove-box, the metal initiator was placed in a Schlenk flask together with the monomer and magnetic stirring bar. The Schlenk flask was sealed and removed from the glove box. All subsequent operations were carried out on a vacuum manifold using Schlenk techniques. The required amount of dry, degassed solvent was added with a syringe to the catalyst and the monomer, followed when required by addition of the chain-transfer agent (iPrOH). The resulting mixture was immersed in an oil bath pre-set at the desired temperature and the polymerisation time was measured from this point. The reaction was terminated by addition of acidified $\mathrm{MeOH}$ $(\mathrm{HCl}, 1 \mathrm{wt} \%)$ and the polymer was precipitated in methanol and washed thoroughly. The polymer was then dried to constant weight in a vacuum oven at $55^{\circ} \mathrm{C}$ under dynamic vacuum $\left(<5 \times 10^{-2}\right.$ mbar $)$.

\section{X-ray diffraction crystallography}

Crystals of 1-3, 8-11, $\left\{\mathrm{LO}^{3}\right\} \mathrm{GeCl},\left\{\mathrm{LO}^{3}\right\} \mathrm{SnCl},\left\{\mathrm{LO}^{3}\right\}_{2} \mathrm{~Pb} \cdot \mathrm{C}_{6} \mathrm{H}_{6}$, $\left\{\mathrm{LO}^{3}\right\} \mathrm{H} \cdot \mathrm{LiOTf}, 3 \cdot \mathrm{LiOTf}$ and 7-LiOTf suitable for X-ray diffraction analysis were obtained by recrystallization of the purified products. Diffraction data were collected at $150 \mathrm{~K}$ using a Bruker APEX CCD diffractometer with graphite-monochromated MoK $\alpha$ radiation $(\lambda=0.71073 \AA)$. A combination of $\omega$ and $\Phi$ scans was carried out to obtain at least a unique data set. The crystal structures were solved by direct methods, the remaining atoms were located from difference Fourier synthesis followed by full-matrix least-squares refinement based on $F^{2}$ (the programs SIR97 and SHELXL-97). ${ }^{46}$ Many hydrogen atoms could be found through the Fourier difference analysis. Carbon- and oxygen-bound hydrogen atoms were placed at calculated positions and forced to ride on the attached atom. The hydrogen atom contributions were calculated but not refined. All non-hydrogen atoms were refined with anisotropic displacement parameters. The locations of the largest peaks in the final difference Fourier map calculation as well as the magnitude of the residual electron densities were of no chemical significance. Relevant collection and refinement data are summarised in Tables 5-8.

\section{Acknowledgements}

The authors acknowledge financial support from Total Petrochemicals (grant to V. P.) and the E. U. Erasmus Programme (travel grant to S.-C. R.). We thank Stephen Boyer (London Metropolitan University) for combustion analyses and 
Jean-Paul Guégan (ENSC Rennes) for DOSY NMR measurements. S.-C. R. also acknowledges Dr Ciprian Raț (Babeș-Bolyai University, Cluj-Napoca, Romania) and the National University Research Council of Romania (project TE295/2010).

\section{Notes and references}

1 Poly(lactic acid): Synthesis, Structures, Properties, Processing and Applications, ed. R. Auras, L.-T. Lim, S. E. M. Selke and H. Tsuji, John Wiley and Sons Inc., Hoboken, New Jersey, 2010.

2 For reviews on ROP metal catalysts, see: (a) O. DechyCabaret, B. Martin-Vaca and D. Bourissou, Chem. Rev., 2004, 104, 6147; (b) C. A. Wheaton, P. G. Hayes and B. J. Ireland, Dalton Trans., 2009, 4832; (c) N. Ajellal, J.-F. Carpentier, C. Guillaume, S. M. Guillaume, M. Hélou, V. Poirier, Y. Sarazin and A. Trifonov, Dalton Trans., 2010, 39, 8363; (d) C. M. Thomas, Chem. Soc. Rev., 2010, 39, 165; (e) M. J. Stanford and A. P. Dove, Chem. Soc. Rev., 2010, 39, 486; $(f)$ P. J. Dijkstra, H. Du and J. Feijen, Polym. Chem., 2011, 2, 520; (g) S. Dagorne, M. Normand, E. Kirillov and J.-F. Carpentier, Coord. Chem. Rev., 2013, 257, 1869; (h) A. Sauer, A. Kapelski, C. Fliedel, S. Dagorne, M. Kol and J. Okuda, Dalton Trans., 2013, 42, 9007.

3 (a) M. Cheng, A. B. Attygalle, E. B. Lobkovsky and G. W. Coates, J. Am. Chem. Soc., 1999, 121, 11583; (b) B. M. Chamberlain, M. Cheng, D. R. Moore, T. M. Ovitt, E. B. Lobkovsky and G. W. Coates, J. Am. Chem. Soc., 2001, 123, 3229; (c) C. K. Williams, L. E. Breyfogle, S. K. Choi, W. Nam, V. G. Young Jr., M. A. Hillmyer and W. B. Tolman, J. Am. Chem. Soc., 2003, 125, 11350.

4 (a) T. M. Ovitt and G. W. Coates, J. Am. Chem. Soc., 1999, 121, 4072; (b) T. M. Ovitt and G. W. Coates, J. Am. Chem. Soc., 2002, 124, 1316; (c) N. Nomura, R. Ishii, M. Akakura and K. Aoi, J. Am. Chem. Soc., 2002, 124, 5938; (d) P. Hormnirun, E. L. Marshall, V. C. Gibson, A. J. P. White and D. J. Williams, J. Am. Chem. Soc., 2004, 126, 2688; (e) N. Nomura, A. Akita, R. Ishii and M. Mizuno, J. Am. Chem. Soc., 2010, 132, 1750.

5 (a) C.-X. Cai, A. Amgoune, C. W. Lehmann and J.-F. Carpentier, Chem. Commun., 2004, 330; (b) H. Ma, T. P. Spaniol and J. Okuda, Angew. Chem., Int. Ed., 2006, 45, 7818; (c) A. Otero, J. Fernández-Baeza, A. Lara-Sánchez, C. Alonso-Moreno, I. Márquez-Segovia, L. F. Sánchez-Barba and A. M. Rodríguez, Angew. Chem., Int. Ed., 2009, 48, 2176; (d) M. Bouyahyi, N. Ajellal, E. Kirillov, C. M. Thomas and J.-F. Carpentier, Chem.-Eur. J., 2011, 17, 1872; (e) C. Bakewell, T.-P.-A. Cao, N. Long, X. F. Le Goff, A. Auffrant and C. K. Williams, J. Am. Chem. Soc., 2012, 134, 20577.

6 Selection of references for ring-opening polymerisation catalysts based on other metals: Indium: $(a)$ A. F. Douglas, B. O. Patrick and P. Mehrkhodavandi, Angew. Chem., Int. Ed., 2008, 47, 2290; (b) A. Pietrangelo, S. C. Knight, A. K. Gupta, L. J. Yao, M. A. Hillmyer and W. B. Tolman,
J. Am. Chem. Soc., 2010, 132, 11649. Lithium: (c) B.-T. Ko and C.-C. Lin, J. Am. Chem. Soc., 2001, 123, 7973. Germanium: (d) A. J. Chmura, C. J. Chuck, M. G. Davidson, M. D. Jones, M. D. Lunn, S. D. Bull and M. F. Mahon, Angew. Chem., Int. Ed., 2007, 46, 2280. Tin(II): (e) N. Nimitsiriwat, E. L. Marshall, V. C. Gibson, M. R. J. Elsegood and S. H. Dale, J. Am. Chem. Soc., 2004, 126, 13598; $(f)$ A. P. Dove, V. C. Gibson, E. L. Marshall, H. S. Rzepa, A. J. P. White and D. J. Williams, J. Am. Chem. Soc., 2006, 128, 9834; (g) V. Poirier, T. Roisnel, S. Sinbandhit, M. Bochmann, J.-F. Carpentier and Y. Sarazin, Chem.-Eur. J., 2012, 18, 2998. Group 4 metals: (h) A. L. Zelikoff, J. Kopilov, I. Goldberg, G. W. Coates and M. Kol, Chem. Commun., 2009, 6804; (i) E. L. Whitelaw, M. G. Davidson and M. D. Jones, Chem. Commun., 2011, 47, 10004. Alkaline-earths: (j) Y. Sarazin, B. Liu, T. Roisnel, L. Maron and J.-F. Carpentier, J. Am. Chem. Soc., 2011, 133, 9069; $(k)$ M. G. Cushion and P. Mountford, Chem. Commun., 2011, 47, 2276; $(l)$ B. Liu, T. Roisnel, J.-P. Guégan, J.-F. Carpentier and Y. Sarazin, Chem.-Eur. J., 2012, 18, 6289.

7 (a) A. Kowalski, A. Duda and S. Penczek, Macromolecules, 2000, 33, 689; (b) H. R. Kricheldorf, I. Kreiser-Saunders and A. Stricker, Macromolecules, 2000, 33, 702; (c) A. Kowalski, J. Libiszowski, A. Duda and S. Penczek, Macromolecules, 2000, 33, 1964; (d) A. Kowalski, A. Duda and S. Penczek, Macromolecules, 2000, 33, 7359.

8 (a) J. Krause, S. Reiter, S. Lindner, A. Schmidt, K. Jurkschat, M. Schürmann and G. Bradtmöller, DE 102008021 980A1, 2009; (b) T. Zöller, L. Iovkova-Berends, C. Dietz, T. Berends and K. Jurkschat, Chem.-Eur. J., 2011, 17, 2361.

9 A. Dumitrescu, H. Gornitzka, B. Martin-Vaca, D. Bourissou, G. Bertrand and J.-B. Cazaux, WO 2001088 014A1, 2001.

10 (a) A. Kowalski, J. Libiszowski, A. Duda and S. Penczek, Macromolecules, 2000, 33, 1964; (b) A. P. Dove, V. C. Gibson, E. L. Marshall, A. J. P. White and D. J. Williams, Chem. Commun., 2001, 283; (c) K. B. Aubrecht, M. A. Hillmyer and W. B. Tolman, Macromolecules, 2002, 35, 644; (d) N. Nimitsiriwat, V. C. Gibson, E. L. Marshall, A. J. P. White, S. H. Dale and M. R. J. Elsegood, Dalton Trans., 2007, 4464; (e) N. Nimitsiriwat, V. C. Gibson, E. L. Marshall and M. R. J. Elsegood, Dalton Trans., 2009, 3710; $(f)$ K. Phomphrai, C. Pongchan-o, W. Thumrongpatanaraks, P. Sangtrirutnugul, P. Kongsaeree and M. Pohmakotr, Dalton Trans., 2011, 40, 2157; $(g) \quad$ P. Piromjitpong, P. Ratanapanee, W. Thumrongpatanaraks, P. Kongsaeree and K. Phomphrai, Dalton Trans., 2012, 41, 12704.

11 H. R. Kricheldorf and C. Boettcher, J. Macromol. Sci., Pure Appl. Chem., 1993, 30, 441.

12 For Ge(Iv) and $\mathrm{Sn}(\mathrm{Iv})$ catalysts, see ref. $6 d$ and: (a) M. H. Chisholm and E. E. Delbridge, Chem. Commun., 2001, 1308; (b) H. R. Kricheldorf and D. Langanke, Polymer, 2002, 43, 1973; (c) A. F. Reema and A.-C. Albertsson, J. Polym. Sci., Part A: Polym. Chem., 2003, 41, 3074; (d) M. H. Chisholm and E. E. Delbridge, New J. Chem., 
2003, 27, 1167; (e) M. H. Chisholm and E. E. Delbridge, New J. Chem., 2003, 27, 1177.

13 (a) Z. Zheng, G. Zhao, R. Fablet, M. Bouyahyi, C. M. Thomas, T. Roisnel, O. Casagrande Jr. and J.-F. Carpentier, New J. Chem., 2008, 32, 2279; (b) V. Poirier, T. Roisnel, J.-F. Carpentier and Y. Sarazin, Dalton Trans., 2009, 9820; (c) Y. Sarazin, V. Poirier, T. Roisnel and J.-F. Carpentier, Eur. J. Inorg. Chem., 2010, 3423; (d) Y. Sarazin, D. Roşca, V. Poirier, T. Roisnel, A. Silvestru, L. Maron and J.-F. Carpentier, Organometallics, 2010, 29, 6569; (e) V. Poirier, T. Roisnel, J.-F. Carpentier and Y. Sarazin, Dalton Trans., 2011, 40, 523; $(f)$ B. Liu, T. Roisnel and Y. Sarazin, Inorg. Chim. Acta, 2012, 380, 2; (g) M. Bouyhayi, Y. Sarazin, O. L. Casagrande Jr. and J.-F. Carpentier, Appl. Organomet. Chem., 2012, 26, 681; (h) B. Liu, T. Roisnel, L. Maron, J.-F. Carpentier and Y. Sarazin, Chem.-Eur. J., 2013, 19, 3986; (i) S.-C. Roșca, D.-A. Roșca, V. Dorcet, C. M. Kozak, F. M. Kerton, J.-F. Carpentier and Y. Sarazin, Dalton Trans., 2013, 42, 9361.

14 (a) L. Wang, C. Kefalidis, S. Sinbandhit, V. Dorcet, J.-F. Carpentier, L. Maron and Y. Sarazin, Chem.-Eur. J., DOI: 10.1002/chem.201301751; (b) L. Wang, M. Bochmann, R. D. Cannon, J.-F. Carpentier, T. Roisnel and Y. Sarazin, submitted.

15 The Chemistry of Metal Phenolates, ed. J. Zabicky, J. Wiley \& Sons Ltd, 2013, Online ISBN: 9780470682531, DOI: 10.1002/9780470682531.pat0606.

16 (a) J. Barrau and G. Rima, Coord. Chem. Rev., 1998, 178-180, 593; (b) N. Tokitoh and R. Okazaki, Coord. Chem. Rev., 2000, 210, 251.

17 M. Veith, Angew. Chem., Int. Ed. Engl., 1987, 26, 1.

18 B. Çetinkaya, I. Gumrukcu, M. F. Lappert, J. L. Atwood, R. D. Rogers and M. J. Zaworotko, J. Am. Chem. Soc., 1980, 102, 2088.

19 D. A. Dickie, I. S. MacIntosh, D. D. Ino, Q. He, O. A. Labeodan, M. C. Jennings, G. Schatte, C. J. Walsby and J. A. C. Clyburne, Can. J. Chem., 2008, 86, 20.

20 B. D. Rekken, T. M. Brown, M. M. Olmstead, J. C. Fettinger and P. P. Power, Inorg. Chem., 2013, 52, 3054.

21 Selected examples: (a) D. A. Atwood, J. A. Jegier, K. J. Martin and D. Rutherford, J. Organomet. Chem., 1995, 503, C4; (b) J. Barrau, G. Rima and T. El Amraoui, Inorg. Chim. Acta, 1996, 241, 9; (c) C. Drost, P. B. Hitchcock, M. F. Lappert and L. J.-M. Pierssens, Chem. Commun., 1997, 1141; (d) H. V. Rasika Dias and Z. Wang, J. Am. Chem. Soc., 1997, 119, 4650; (e) W.-P. Leung, W.-H. Kwok, L.-H. Weng, L. T. C. Law, Z. Y. Zhou and T. C. W. Mak, J. Chem. Soc., Dalton Trans., 1997, 4301; (f) C. J. Cardin, D. J. Cardin, S. P. Constantine, M. G. B. Drew, H. Rashid, M. A. Convery and D. Fenske, J. Chem. Soc., Dalton Trans., 1998, 2749; (g) H. Schmidt, S. Keitemeyer, B. Neumann, H.-G. Stammler, W. W. Schoeller and P. Jutzi, Organometallics, 1998, 17, 2149; (h) S. Benet, C. J. Cardin, D. J. Cardin, S. P. Constantine, P. Heath, H. Rashid, S. Teixeira, J. H. Thorpe and A. K. Todd, Organometallics, 1999, 18, 389; (i) P. Jutzi, S. Keitemeyer, B. Neumann and H.-G. Stammler, Organometallics, 1999, 18, 4778; (j) M. C. Kuchta, J. M. Hahn and G. Parkin, J. Chem. Soc., Dalton Trans., 1999, 3559; (k) C. Kitamura, N. Maeda, N. Kamada, M. Ouchi and A. Yoneda, J. Chem. Soc., Perkin Trans. 1, 2000, 781; (l) Y. Ding, H. W. Roesky, M. Noltemeyer and H.-G. Schmidt, Organometallics, 2001, 20, 1190; (m) L. W. Pineda, V. Jancik, K. Starke, R. B. Oswald and H. W. Roesky, Angew. Chem., Int. Ed., 2006, 45, 2602; (n) J. R. Fulton, P. B. Hitchcock, N. C. Johnstone and E. C. Y. Tam, Dalton Trans., 2007, 3360; (o) S. Yao, S. Block, M. Brym and M. Driess, Chem. Commun., 2007, 3844; ( $p$ ) A. Jana, I. Objartel, H. W. Roesky and D. Stalke, Dalton Trans., 2010, 39, 4647; (q) L. Ferro, P. B. Hitchcock, M. P. Coles, H. Cox and J. R. Fulton, Inorg. Chem., 2011, 50, 1879; (r) M. J. Taylor, A. J. Saunders, M. P. Coles and J. R. Fulton, Organometallics, 2011, 30, 1334; $(s)$ A. Jana, S. Pillai Sarish, H. W. Roesky, D. Leusser, I. Objartel and D. Stalke, Chem. Commun., 2011, 47, 5434; $(t)$ L. Ferro, P. B. Hitchcock, M. P. Coles and J. R. Fulton, Inorg. Chem., 2012, 51, 1544; (u) Y. Yang, N. Zhao, H. Zhu and H. W. Roesky, Organometallics, 2012, 31, 1958; (v) L. Álvarez-Rodríguez, J. A. Cabeza, P. García-Álvarez and D. Polo, Organometallics, 2013, 32, 3557.

22 N. N. Zemlyansky, I. V. Borisova, M. G. Kuznetsova, V. N. Khrustalev, Y. A. Ustynyuk, M. S. Nechaev, V. V. Lunin, J. Barrau and G. Rima, Organometallics, 2003, 22, 1675.

23 (a) J. Barrau, G. Rima and T. El-Amra, J. Organomet. Chem., 1998, 561, 167; (b) J. Barrau, G. Rima and T. El Amraoui, Organometallics, 1998, 17, 607.

24 M. Novotný, Z. Padělková, J. Holeček and A. Růžička, J. Organomet. Chem., 2013, 733, 71.

25 V. N. Khrustalev, I. A. Portnyagin, N. N. Zemlyansky, I. V. Borisova, M. S. Nechaev, Y. A. Ustynyuk, M. Y. Antipin and V. Lunin, J. Organomet. Chem., 2005, 690, 1172.

26 Complexes 5-7 are taken from ref. $6 g$ and $14 a$.

27 By contrast, we had previously found that salt metathesis was more convenient and more reliable during similar reactions with alkaline-earth metals, see ref. $6 l$.

28 The synthesis of $\left\{\mathrm{L}^{4}\right\} \mathrm{Pb}\left(\mathrm{N}\left(\mathrm{SiMe}_{3}\right)_{2}\right)$ was attempted but not pursued because of its high kinetic lability and the difficulties encountered in the syntheses of $\mathbf{4}$ and $\mathbf{8}$.

29 By contrast, zinc and alkaline-earth amides $\left[\mathrm{M}\left(\mathrm{N}\left(\mathrm{SiMe}_{3}\right)_{2}\right)_{2}\right]_{n}$ decompose in chlorinated solvents with rates increasing according to $\mathrm{M}=\mathrm{Zn} \ll \mathrm{Mg} \ll \mathrm{Ca}<\mathrm{Sr}<\mathrm{Ba}$, with decomposition occurring in a matter of seconds for $\mathrm{Ba}$ and minutes for Ca; Y. Sarazin, unpublished results.

30 (a) R. D. Shannon, Acta Crystallogr., Sect. A: Cryst. Phys., Diffr., Theor. Gen. Cryst., 1976, A32, 751; (b) J. C. Slater, J. Chem. Phys., 1964, 39, 3199.

31 This was previously confirmed by Natural Bonding Order analysis for the stannylenes 5-7 (orbital participation: $89 \%$ s character, $11 \% \mathrm{p}$ ), see ref. $14 a$.

32 (a) C. J. Pedersen, J. Am. Chem. Soc., 1967, 89, 7017; (b) J. J. Christensen, D. J. Eatough and R. M. Izatt, Chem. 
Rev., 1974, 74, 351; (c) K. E. Krakowiak, J. S. Bradshaw and D. J. Zamecka-Krakowiak, Chem. Rev., 1989, 89, 929; (d) G. W. Gokel, W. M. Leevy and M. E. Weber, Chem. Rev., 2004, 104, 2723.

33 V. Arens, C. Dietz, D. Schollmeyer and K. Jurkschat, Organometallics, 2013, 32, 2775.

34 W. J. Gee and S. R. Batten, Eur. J. Inorg. Chem., 2013, 3240.

35 S. Itoh, H. Kumei, S. Nagatomo, T. Kitagawa and S. Fukuzumi, J. Am. Chem. Soc., 2001, 123, 2165.

36 A. W. Addison, T. N. Rao, J. Reedijk, J. van Rijn and G. C. J. Verschoor, Chem. Soc., Dalton Trans., 1984, 1349.

37 Diffusion coefficient measurements by ${ }^{1} \mathrm{H}$ DOSY NMR in benzene- $d_{6}$ at $25{ }^{\circ} \mathrm{C}$ for 3 and 3-LiOTf showed that the alkali cation remained in position inside the macrocycle in solution, or at least that strong interactions between the germylene and LiOTf persisted.

38 S. J. Lancaster, A. Rodriguez, A. Lara-Sanchez, M. D. Hannant, D. A. Walker, D. H. Hughes and M. Bochmann, Organometallics, 2002, 21, 451.

39 T. Aida and S. Inoue, Acc. Chem. Res., 1996, 29, 39.

40 M. Save, M. Schappacher and A. Soum, Macromol. Chem. Phys., 2002, 203, 889.
41 (a) M. H. Chisholm, J. Gallucci and K. Phomphrai, Chem. Commun., 2003, 48; (b) M. H. Chisholm, J. Gallucci and K. Phomphrai, Inorg. Chem., 2004, 43, 6717.

42 (a) E. Piedra-Arroni, P. Brignou, A. Amgoune, S. M. Guillaume, J.-F. Carpentier and D. Bourissou, Chem. Commun., 2011, 47, 9828; (b) P. Brignou, S. M. Guillaume, T. Roisnel, D. Bourissou and J.-F. Carpentier, Chem.-Eur. J., 2012, 18, 9360.

43 M. J. S. Gynane, D. H. Harris, M. F. Lappert, P. P. Power, P. Rivière and M. Rivière-Baudet, J. Chem. Soc., Dalton Trans., 1977, 2004.

44 C. D. Schaeffer and J. J. Zuckerman, J. Am. Chem. Soc., 1974, 96, 7160.

45 (a) S. Groysman, E. Sergeeva, I. Goldberg and M. Kol, Inorg. Chem., 2005, 44, 8188; (b) M. M. Hänninen, R. Sillanpää, H. Kiveläb and A. Lehtonen, Dalton Trans., 2011, 40, 2868.

46 (a) A. Altomare, M. C. Burla, M. Camalli, G. L. Cascarano, C. Giacovazzo, A. Guagliardi, A. G. G. Moliterni, G. Polidori and R. Spagna, J. Appl. Crystallogr., 1999, 32, 115; (b) G. M. Sheldrick, SHELXL-97, Program for refinement of crystal structures, University of Göttingen, Germany, 1997. 